Geohydrology and Model Analysis of Stream-Aquifer System Along the Arkansas River in Kearny and Finney Counties, Southwestern Kansas

United States Geological Survey Water-Supply Paper 2253

Prepared in cooperation with the Kansas State Board of Agriculture, Division of Water Resources 


\section{Geohydrology and Model Analysis of Stream-Aquifer System Along the Arkansas River in Kearny and}

Finney Counties, Southwestern Kansas

By L. E. DUNLAP, R. J. LINDGREN, and C. G. SAUER

Prepared in cooperation

with the Kansas State

Board of Agriculture, Division of Water

Resources 


\section{DEPARTMENT OF THE INTERIOR WILLIAM P. CLARK, Secretary \\ U.S. GEOLOGICAL SURVEY \\ Dallas L. Peck, Director}

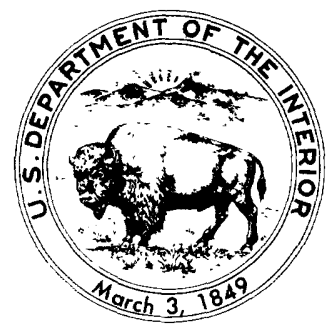

Library of Congress Cataloging in Publication Data

Dunlap, L. E.

Geohydrology and model analysis of stream-aquifer system along the Arkansas River in Kearny and Finney Counties, southwestern Kansas

(United States Geological Survey water-supply paper ; 2253)

"Prepared in cooperation with the Kansas State Board of Agriculture, Division of Water Resources."

Bibliography: $52 \mathrm{p}$.

Supt. of Docs. no.: I 19.13:2253

1. Aquifers-Kansas-Kearny County. 2. Aquifers-Kansas-Finney County. 3. Aquifers-Arkasas River Valley. I. Lindgren, Richard J. II. Sauer, C. G. III. Kansas. State Board of Agriculture. Division of Water Resources. IV. Title. V. Series: U.S. Geological Survey water-supply paper ; 2253.

QB1199.3.K2D86 $553.7^{\prime} 9^{\prime} 09781425$

83-600375

For sale by the Branch of Distribution

U.S. Geological Survey

604 South Pickett Street

Alexandria, VA 22304 


\section{CONTENTS}

Definition of terms VI

Abstract 1

Introduction 1

Purpose and scope 2

Methods of investigation 3

Previous investigations and data collection $\mathbf{3}$

Computer models 3

Well-numbering system $\mathbf{3}$

Acknowledgments 4

Hydrology of stream-aquifer system 4

Geohydrologic setting 4

Cretaceous rocks 4

Undifferentiated Miocene and Pleistocene deposits 5

Upper Pleistocene and Holocene deposits 7

Arkansas River 7

Ground water 7

Bedrock aquifer 7

Lower aquifer 8

Confining zone 8

Upper aquifer 8

Valley aquifer 8

Surface water 9

Arkansas River 9

Irrigation canals 9

Use of ground water 11

Irrigation 11

Arkansas River valley

11

High plains 11

Sandhills 11

Industry 13

Municipal 15

Historic hydrologic response 15

Recharge 15

Infiltration from precipitation and irrigation water $\mathbf{1 5}$

Arkansas River seepage 15

Irrigation-canal seepage 18

Subsurface inflow 18

Discharge 18

Pumpage 18

Subsurface outflow 18

Ground-water evapotranspiration 19

Streamflow 19

Change in storage 19

Valley aquifer 19

River stage versus ground-water levels 19

Sinkholes 20

Lower aquifer $\mathbf{2 0}$

Interrelationship of aquifers $\mathbf{2 2}$

Computer model analysis 25

Three-dimensional model 25

Finite-difference grid 25

Aquifer leakance $\mathbf{2 7}$

Model boundaries 27 
Computer model analysis - Continued

Steady-state model $\mathbf{2 7}$

Boundary conditions 27

Precipitation 28

Hydraulic conductivity $\mathbf{2 8}$

Specific yield 28

Leakance 28

Simulated hydrologic response $\mathbf{2 8}$

Transient model 28

Time steps and pumping periods $\mathbf{3 0}$

Boundary conditions $\mathbf{3 0}$

Hydraulic conductivity $\mathbf{3 0}$

Storage coefficient and specific yield $\mathbf{3 0}$

Leakance $\mathbf{3 1}$

Pumpage 32

Simulated hydrologic response $\mathbf{3 2}$

Water budget 34

Sensitivity tests 34

Response of valley aquifer $\mathbf{3 7}$

Response of lower aquifer $\mathbf{3 8}$

Hypothetical conditions 39

Response to pumpage changes in sandhills for 1974-80 39

Projected responses to hypothetical conditions of streamflow and pumpage for 1981-2005 41

Response to streamflow conditions of $1979 \quad \mathbf{4 1}$

Response to streamflow conditions of $1980 \quad 44$

Response to increased industrial pumpage $\mathbf{4 8}$

Summary 48

Response to increased irrigation pumpage 48

References $\mathbf{5 1}$

\section{FIGURES}

1. Map showing location of moratorium area and phase-I and II study areas 2

2. Diagram showing well-numbering system 4

3. Hydrogeologic section in Finney County $\mathbf{5}$

4. Map showing configuration of bedrock surface in study area 6

5. Graph showing annual discharge of Arkansas River at Garden City, 1923-50 average and 1951-69 9

6. Graph showing mean monthly discharge of Arkansas River at Lakin, 1978-81 9

7. Map showing location of irrigation canals and seepage-loss measurement sites 10

8. Graph showing annual diversion rates by irrigation canals, 1970-81 11

9. Map showing location of irrigation wells and Sunflower Electric wells within unconsolidated aquifer boundary, $1980 \mathbf{1 2}$

10. Graph showing cumulative number of applications to appropriate ground water in Kearny and Finney Counties, 1940-67 13

11. Map showing generalized physiographic areas within study area $\mathbf{1 4}$

12. Map showing location of streamflow-gaging stations and observation wells $\mathbf{1 6}$

13. Graph showing annual precipitation (1970-80) and normal precipitation (194170) at Garden City 17

14. Graph showing comparison of Arkansas River discharge between Amazon Canal and Farmers Canal 17

15. Hydrograph of a representative well in valley aquifer near Deerfield, 1964-81 


\section{FIGURES}

16. Graph showing comparison of Arkansas River stage to water-table level in valley aquifer near Kendall, 1979-81 20

17. Hydrograph of a representative well in lower aquifer on high plains, 1965-80 21

18. Graph showing water-level fluctuations in upper and lower aquifers during 1968 in observation wells $23-34 \mathrm{~W}-26 \mathrm{CDC} 1$ and $23-34 \mathrm{~W}-26 \mathrm{CDC} 222$

19. Hydrograph of irrigation well $23-34 \mathrm{~W}-26 \mathrm{CCC}$, representative of lower aquifer on high plains, 1966-80 23

20. Graph showing relationship between Arkansas River stage and water levels in unconsolidated aquifer system near Lakin, 1978-81 25

21. Map showing finite-difference grid used in model analyses $\mathbf{2 6}$

22. Map showing comparison of measured and simulated water levels for steady-state conditions during 194029

23. Maps showing boundary conditions used in transient model $\mathbf{3 1}$

24. Graph showing comparison of potential well yield and saturated thickness from Gutentag and others (1972) to well-yield decrease from equation $4 \mathbf{3 3}$

25. Graphs showing measured and simulated water levels in selected observation wells, 1974-80 33

26. Map showing comparison of water levels in valley and upper aquifers measured during January 1981, and simulated for December 31, 198035

27. Map showing comparison of potentiometric surfaces in lower aquifer measured during January 1981, and simulated for December 31, 198036

28. Schematic diagram illustrating simulated water budget for unconsolidated aquifer system, 198038

29. Graphs showing response of simulated hydraulic heads in valley aquifer to changes in selected hydrologic values $\mathbf{3 9}$

30. Graphs showing response of simulated hydraulic heads in lower aquifer to changes in selected hydrologic values $\mathbf{4 0}$

31. Map showing simulated decline in potentiometric surface of lower aquifer, 1974 80 , with actual $1974-80$ pumpage in sandhills $\mathbf{4 2}$

32. Map showing simulated decline in potentiometric surface of lower aquifer, 1974 80, with no pumpage in sandhills from 1974-80 43

33. Graphs showing simulated water levels in selected observation wells, with and without pumpage in sandhills, 1974-80 44

34. Map showing simulated decline in potentiometric surface of lower aquifer during 1981-2005, using 1980 normal pumpage and 1979 recharge from surface water (projection 1) 45

35. Map showing simulated saturated thickness in lower aquifer during 2005, resulting from hypothetical conditions used in projection $1 \quad 46$

36. Map showing simulated decline in potentiometric surface of lower aquifer during 1981-2005, using 1980 normal pumpage and 1980 recharge from surface water (projection 2) 47

37. Map showing simulated decline in potentiometric surface of lower aquifer during 1981-2005, in addition to projection-1 declines, as a result of additional pumpage needs by electric-generating units 2 and 3 at the Sunflower Electric Plant (projection 3) 49

38. Map showing simulated decline in potentiometric surface of lower aquifer during 1981-2005, using 1980 normal pumpage and 1979 recharge from surface water, plus additional development from new irrigation wells (projection 4) $\mathbf{5 0}$

\section{TABLES}

1. Simulated water budget for unconsolidated aquifer system, 1974-80 37

2. Simulated water budget for unconsolidated aquifer system, $1980 \quad 37$

3. Summary of sensitivity tests

\section{1}




\section{DEFINITION OF TERMS}

Aquifer-A formation, group of formations, or part of a formation that contains sufficient saturated permeable material to yield significant quantities of water to wells and springs.

Aquifer leakance-Ratio of the vertical hydraulic conductivity of the confining zone to the thickness of the confining zone.

Available soil moisture - The quantity of water in soil that is available to plants.

Confined aquifer-Aquifer in which an artesian water body is present. The water level in a well completed in a confined aquifer is above the top of the artesian water body.

Constant-flux boundary-A model boundary condition that has a fixed value of volumetric flow rate per unit area (discharge) across the boundary.

Constant-gradient boundary-A model boundary condition that changes flow rate across the boundary as saturated thickness changes. The hydraulic gradient across the boundary remains constant with changes in saturated thickness.

Constant-head boundary-A model boundary condition that has a fixed value of static head, which is the height above a standard datum of the surface of a column of water that can be supported by the static pressure at a given point.

Crop-water demand-Volume of water that is used by vegetative growth in transpiration and building of plant tissue and that is evaporated from adjacent soil or from plant foliage.

Digital model-A simplified mathematical representation of a complex system. A computer program used to solve ground-water flow equations.

Discharge-Flow of water expressed as a volume per unit of time.

Ephemeral stream-Stream that flows briefly in direct response to precipitation in the immediate locality and has a channel that is, at all times, above the water table.

Evapotranspiration-Volume of water that is lost to the atmosphere by transpiration from vegetative growth and by evaporation from the soil or from the aquifer in shallow water-table areas.

Hydraulic conductivity-Volume of water at the prevailing kinematic viscosity that will move through a porous medium in unit time under a unit hydraulic gradient through a unit area measured at right angles to the direction of flow.

Hydraulic gradient - Change in static head per unit of distance in a given direction.

Hydraulic head-Height above a standard datum of the surface of a column of water that can be supported by the static pressure at a given point.

Infiltration rate-Rate at which water made available at the ground surface enters into the soil zone.

National Geodetic Vertical Datum of 1929 (NGVD)—A geodetic datum derived from a general adjustment of the first-order level nets of both the United States and Canada. NGVD of 1929 is referred to as sea level in this report.

Perennial stream-Stream that flows throughout the year and has a channel that generally is below the water table.

Potentiometric surface-A surface that represents the hydrostatic head. In a confined (artesian) aquifer, the water is under a pressure significantly greater than atmospheric, and the surface is defined by the levels to which water stands in wells above the water body tapped. In an unconfined aquifer, the surface coincides with the water table.

Pumpage-Withdrawal of ground water from the aquifer by pumps, largely for municipal and agricultural purposes.

Recharge-Amount of water added to the zone of saturation.

Saturated thickness-Amount of water-bearing material filled with water under pressure greater than atmospheric. 
Specific yield-Ratio of the volume of water that the saturated material will yield by gravity to the volume of the material.

Steady state-Equilibrium conditions when hydraulic heads and the volume of water in storage do not change significantly with time.

Storage coefficient-Volume of water an aquifer releases from or takes into storage per unit surface area of the aquifer per unit change in head.

Transient state-Nonequilibrium conditions when hydraulic heads and the volume of water in storage do change significantly with time.

Transmissivity - Rate at which water of the prevailing kinematic viscosity is transmitted through a unit width of an aquifer under a unit hydraulic gradient.

Unconfined aquifer-Aquifer in which a water-table body is present.

Water table-Surface in an unconfined water body at which the pressure is atmospheric. It is defined by the levels at which water stands in wells that penetrate the water body just far enough to hold standing water. 


\section{Conversion Table}

Inch-pound units of measurement in this report may be converted to the International System of Units (SI) using the following conversion factors:

\begin{tabular}{|c|c|c|}
\hline $\begin{array}{l}\text { To convert from } \\
\text { inch-pound unit }\end{array}$ & $\begin{array}{l}\text { To SI } \\
\text { unit }\end{array}$ & Multiply by \\
\hline inch & millimeter & 25.4 \\
\hline foot & meter & 0.3048 \\
\hline mile & kilometer & 1.609 \\
\hline acre & square meter & 4,047 \\
\hline square mile & square kilometer & 2.590 \\
\hline acre-foot & cubic meter & 1,233 \\
\hline $\begin{array}{l}\text { acre-foot per year } \\
\text { (acre-ft/yr) }\end{array}$ & cubic meter per year & 1,233 \\
\hline $\begin{array}{l}\text { cubic foot per second } \\
\left(\mathrm{ft}^{3} / \mathrm{s}\right)\end{array}$ & cubic meter per second & 0.02832 \\
\hline $\begin{array}{l}\text { cubic foot per second } \\
\text { per mile }\left[\left(\mathrm{ft}^{3} / \mathrm{s}\right) / \mathrm{mi}\right]\end{array}$ & $\begin{array}{l}\text { cubic meter per second } \\
\text { per kilometer }\end{array}$ & 0.0176 \\
\hline inch per year (in/yr) & millimeter per year & 25.4 \\
\hline foot per day $(\mathrm{ft} / \mathrm{d})$ & meter per day & 0.3048 \\
\hline square foot per day $\left(\mathrm{ft}^{2} / \mathrm{d}\right)$ & square meter per day & 0.09290 \\
\hline foot per year (ft/yr) & meter per year & 0.3048 \\
\hline foot per mile (ft/mi) & meter per kilometer & 0.18943 \\
\hline gallon per minute (gal/min) & liter per second & 0.06309 \\
\hline
\end{tabular}




\title{
Geohydrology and Model Analysis of Stream-Aquifer System Along the Arkansas River in Kearny and Finney Counties, Southwestern Kansas
}

\author{
By L. E. Dunlap, R. J. Lindgren, and C. G. Sauer
}

\section{Abstract}

A study was made, in cooperation with the Division of Water Resources, Kansas State Board of Agriculture, to determine geohydrologic conditions in an area comprising nearly 850,000 acres along the Arkansas River valley in Kearny and Finney Counties, southwestern Kansas. The Arkansas River meanders atop and interacts hydraulically with the area's multilayered, unconsolidated aquifer system. Declines in static water levels in wells in the heavily pumped lower aquifer ranged from 20 to 80 feet during $1974-80$. The river is dry in much of the area.

A digital computer model was calibrated to simulate the trends of historic water levels. Simulated 1974-80 conditions depicted an average annual recharge to the unconsolidated aquifer system of 66,900 acre-feet from precipitation and 36,200 acre-feet from river and canal seepage and boundary inflow. Simulated average annual discharge consisted of 634,800 acre-feet from pumpage and boundary outflow. Simulated average annual recharge to the unconsolidated aquifer system was 531,700 acre-feet less than average annual discharge, indicating the ground-water resource is currently (1982) being mined in the study area.

Simulation also indicated that there would be sufficient saturated thickness in 2005 for irrigation if 1980 hydrologic conditions continued. Seepage losses from the Arkansas River and irrigation canals are a major source of recharge to the unconsolidated aquifer system. Therefore, the amount of flow in the Arkansas River would be important in determining the rate of future waterlevel declines in the study area. Streamflow seepage losses could be decreased by (1) decreasing the number of wells pumping in the study area in order to reduce downward leakage from the valley aquifer, or (2) increasing streamflow discharge in order to recharge the valley aquifer. The rate and direction of flow between the river and the valley aquifer depend on the hydraulic conductivity of the streambed and the hydraulic gradient between the river stage and the water table. As long as river stage remains high, the water table in the valley aquifer continues to rise. Seepage from the river to the valley aquifer decreases as the altitude difference between the river stage and the valley aquifer decreases, becoming insignificant when the water level in the valley aquifer nearly equals river stage. However, a rise in the water table in the valley aquifer because of recharge from the river will correspond to increased downward leakage to the lower aquifer, impeding recharge to the valley aquifer.

\section{INTRODUCTION}

In January 1977, the Chief Engineer of the Division of Water Resources, Kansas State Board of Agriculture, declared a moratorium on approval of applications for permits to appropriate water from an area of 500 square miles along the Arkansas River in Hamilton and Kearny Counties, southwestern Kansas (fig. 1). The moratorium was prompted by a concern over decreasing streamflow and declining water levels in wells and the need for a better understanding of ground- and surface-water interaction along the Arkansas River.

Average annual streamflow at Syracuse decreased from 173,000 acre-feet during $1951-69$ to 68,000 acrefeet during 1970-80. January water levels in wells in the western part of the moratorium area have declined about 4 feet since 1970; water levels in wells in the eastern part of the moratorium area have declined more than 25 feet between 1970 and 1980 .

Since the late 1800's, irrigation companies in Kansas have diverted water from the Arkansas River. Legal rights to this water are predominantly vested; for the most part, they are senior (earlier in time) to ground-water appropriation in the area. Because streamflow during the 1970's has been insufficient to meet legal commitments and satisfy crop demands, the area has become increasingly dependent on ground water for irrigation.

When the moratorium was declared, hydrologic information was insufficient to allow an adequate scientific evaluation of the interaction of ground and surface water and the extent to which diversion from either source might impair water use under existing rights. In particular, a thorough geohydrologic investigation of the area was needed to assess future hydrologic conditions resulting 


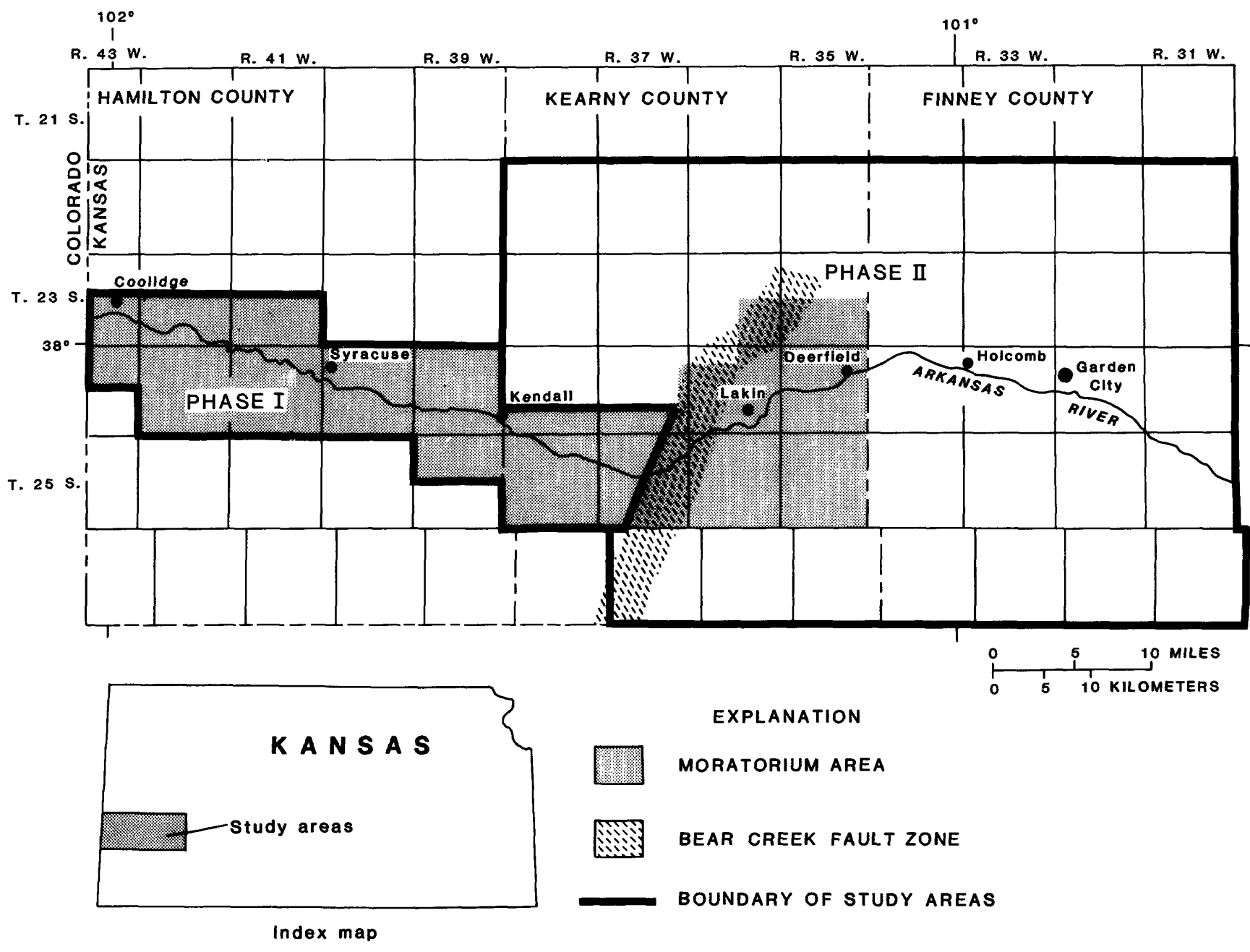

Figure 1. Location of moratorium area and phase-I and II study areas.

from changes in rates of (1) pumpage, (2) streamflow at the Kansas-Colorado State line, and (3) precipitation. Owing to water-management problems associated with a generally inadequate water supply and the need to better understand the stream-aquifer system, the Division of Water Resources, Kansas State Board of Agriculture, in October 1977, entered into a 5-year cooperative study of the moratorium area with the U.S. Geological Survey.

\section{Purpose and Scope}

The purpose of the study is to (1) better define the relat' "'ips between the Arkansas River and water levels in the ncensolidated aquifer system, (2) evaluate the effects (. nges in ground-water levels on changes in streamflow, and (3) construct and calibrate a digital computer model of the unconsolidated aquifer system along the Arkansas River in Hamilton, Kearny, and Finney Counties, to he used as a management tool in assessing future hydrologic conditions.
To expedite model development, study of the moratorium area was divided into two parts (fig. 1). The results for the western part, or phase-I study, are reported in Barker and others (1981). The study of the geohydrology of the phase-I area was limited to a relatively narrow, shallow alluvial trough. The Arkansas River in phase-I area is a perennial stream and is the principal factor affecting water-level changes in the alluvial aquifer. The phaseII study (eastern part) was expanded beyond the moratorium area to include nearly 850,000 acres that would incorporate the effects of ground-water pumpage in Kearny and Finney Counties. The study of the geohydrology of the phase-II area included a thick, multilayered aquifer system. In the phase-II area, the Arkansas River is dry in most reaches the majority of the time, and pumpage is the principal factor affecting water-level changes.

This report decribes the geohydrology of Kearny and Finney Counties along the Arkansas River, studied under phase II, and a computer-model analysis of the associated stream-aquifer system. The report is written for the scientifically informed public and for State and local 
water agencies who may use the results of the investigation to formulate water-management policies to improve the conjunctive use of ground and surface water within the constraints of the water-rights structure in Kansas.

"Study area," as it appears henceforth, refers only to that part of Kearny and Finney Counties studied under phase II. This phase-II area, characterized by an unconsolidated aquifer system, lies east of Hamilton County and west of Gray County. It is bounded on the south by Grant and Haskell Counties and on the north by Township 21 South.

\section{Methods of Investigation}

\section{Previous Investigations and Data Collection}

A literature search and data collection dominated the early part of the study. Much data were available from previous and ongoing studies of the area. Slichter (1906) described the river discharge, ground-water movement, and pumpage along the Arkansas River at the turn of the century. McLaughlin (1943) and Latta (1944) reported water levels and described pumpage along the Arkansas River before water levels began to decline. Meyer and others (1970) provided information on aquifer characteristics and the geology of the study area. Gutentag and others (1972) and Gutentag, Lobmeyer, and McGovern (1972) defined the configuration of the bedrock surface.

Historical surface-water data were obtained primarily from publications of the U.S. Geological Survey and from annual reports of the Arkansas River Compact Administration. Rates of canal diversion, areas of surfacewater irrigation, and location of some irrigation wells were provided from records kept by the office of the Division of Water Resources, Kansas State Board of Agriculture, in Garden City, Kans.

Climatic data published by the National Oceanic and Atmospheric Administration (1940-80) were used to define precipitation, temperature, and percentage of possible sunshine over the study area. These data were used with irrigated-crop acreage data from the U.S. Department of Agriculture, Agricultural Stabilization and Conservation Service, to determine irrigation pumpage.

Soil characteristics of the study area were extracted from publications of the U.S. Department of Agriculture, Soil Conservation Service $(1963,1965)$. Moisture-holding and infiltration properties of soils and irrigation efficiencies were provided by the Kansas State University Extension office in Garden City.

Data-collection activities during the study included (1) the inventory of irrigation wells within the moratorium area in Kearny County and within the study area in Finney County, (2) seepage-loss studies of the Farmers Canal in western Finney County, and (3) measurement of water levels in 140 observation wells on a weekly, monthly, or quarterly basis.

During the study, complete-record streamflowgaging stations were installed on the Arkansas River downstream from the Amazon Canal headgate near Kendall (spring 1978) and at Lakin (spring 1978). These installations were used to monitor streamflow rates and to establish seepage losses to the aquifer system.

Using water-rotary and hollow-stem augering equipment, a total of 17 observation wells were installed at eight locations along the Arkansas River. Installation sites near Garden City, Holcomb (two locations), and Lakin were equipped with continuous water-level recorders. Water levels in other wells were measured manually on a weekly basis. The observation wells were used to monitor differences in water levels in the aquifer system. The installation site near Lakin also monitored river stage (during periods of time when flow occurred in the river) in relation to the ground-water levels. These data were used to evaluate aquifer response to streamflow and well pumping.

\section{Computer Models}

Ground-water management is becoming increasingly important in Kansas. The Division of Water Resources, Kansas State Board of Agriculture, needs hydrogeologic information to insure the conservation and proper management of ground and surface waters. To meet this demand, digital flow models have been developed that can mathematically simulate the ground-water flow system. These models incorporate horizontal and vertical flow equations, aquifer characteristics, and discharge from and recharge to the aquifer to predict the water-level response.

This study used a three-dimensional ground-water flow model developed by Trescott (1975) to simulate the multilayered, unconsolidated aquifer system. A soil-zone model (Lappala, 1978) was used in conjunction with cropacreage data to estimate irrigation pumpage, which is the major source of discharge from the unconsolidated aquifer system.

\section{Well-Numbering System}

The well-numbering system used in this report (fig. 2) gives the location of a well or test hole according to the U.S. Bureau of Land Management's system of land subdivision. In this system, the first set of digits of a well number indicates the township; the second set, the range east or west of the Sixth Principal Meridian; and the third set, the section. The first letter after the section number denotes the quarter section or 160-acre tract; the second, the quarter-quarter section or 40 -acre tract; and the third, the quarter-quarter-quarter section or 10-acre tract. The 160-acre tract, the 40-acre tract, and the 10- 


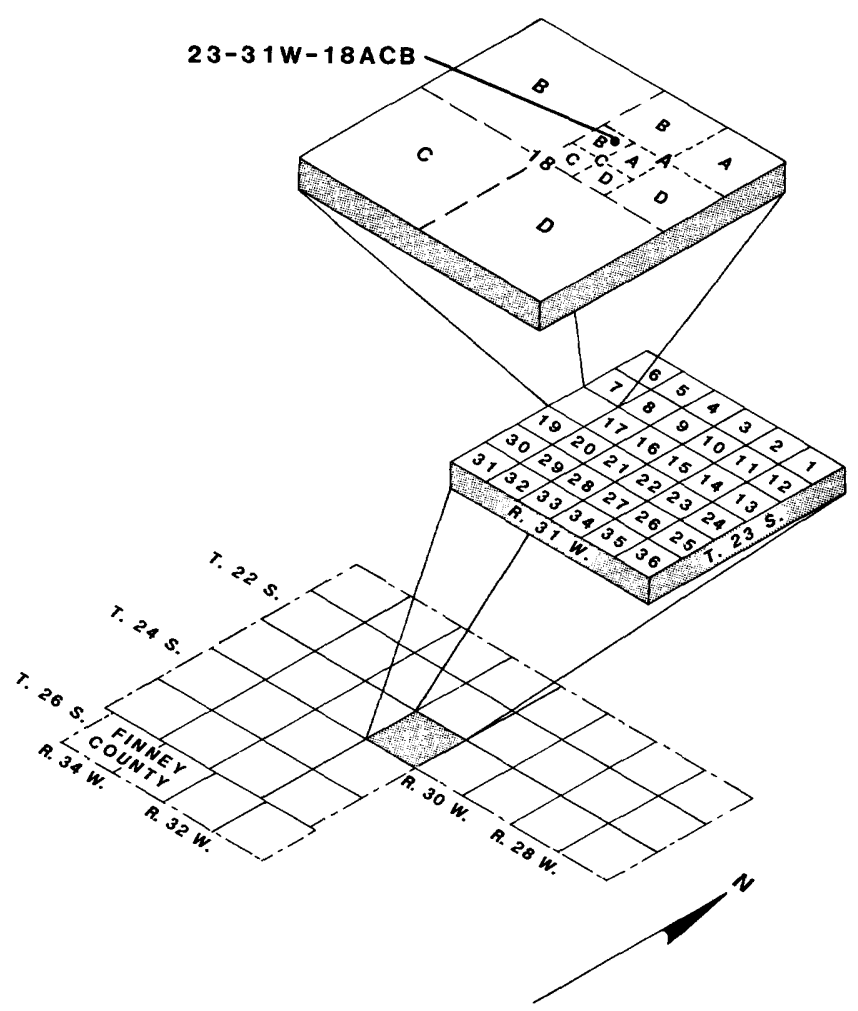

Figure 2. Well-numbering system.

acre tract are designated $\mathrm{A}, \mathrm{B}, \mathrm{C}$, and $\mathrm{D}$ in a counterclockwise manner, beginning in the northeast quadrant. Where two or more wells are located in a 10-acre tract, consecutive numbers are added in the order in which the wells were inventoried. Thus, a well numbered $23-31 \mathrm{~W}-$ $18 \mathrm{ACB}$ indicates that the well is in the NW1/4 SW $1 / 4 \mathrm{NE}^{1 / 4}$ sec. 18 , T. 23 S., R. $31 \mathrm{~W}$.

\section{Acknowledgments}

Appreciation and thanks are expressed to many Kearny and Finney County residents and individual water users in the study area who permitted access to their property and supplied information about their wells.

Howard Corrigan and the staff of the Division of Water Resources, Kansas State Board of Agriculture, in Garden City, Kans., provided timely surface-water-diversion and water-level data. James G. Thomas of the Kansas State University Extension office in Garden City provided advice on irrigation efficiencies for the soil-zone model. Kenneth R. Watts of the U.S. Geological Survey's staff in Garden City provided comprehensive hydraulic-conductivity data. Gordon O'Dell of the U.S. Department of Agriculture, Agricultural Stabilization and Conservation Service, provided crop-acreage information.

\section{HYDROLOGY OF STREAM-AQUIFER SYSTEM}

\section{Geohydrologic Setting}

Thick, layered, unconsolidated sediments of Miocene and Pleistocene age underlie the study area. The ground water in these sediments is the key ingredient of the thriving agricultural economy of the area.

The Arkansas River is also important to the area because it provides water for irrigation canals. Additionally, water in the river serves to recharge the unconsolidated aquifer system. The river flows from west to east across the study area.

The land surface in the study area varies from a flat upland in the north to rolling sand dunes in the south. The Arkansas River and its flood plain separate the uplands from the sandhills.

Overland runoff contributes very little flow to the Arkansas River. The flat uplands drain to sinkholes or to ephemeral streams, most of which do not reach the river. The rapid infiltration rate of the sandhill soil does not allow runoff to leave the southern part of the study area.

\section{Cretaceous Rocks}

Bedrock of Cretaceous age underlies the Miocene and Pleistocene deposits. The Cretaceous rocks dip to the northeast, resulting in successively older rocks subcropping from north to south across the study area (fig. 3). For example, in the southern part of the study area, the bedrock surface is formed on undifferentiated Lower Cretaceous rocks. Moving progressively northward, the bedrock surface is formed successively on Graneros Shale, Greenhorn Limestone, and Carlile Shale of the Upper Cretaceous Series. These rocks are in stratigraphic position as the altitude of the bedrock surface rises northward.

The formations below the Upper Cretaceous Series rocks and above the Permian System are difficult to differentiate in lithology, both horizontally and vertically. Therefore, the Lower Cretaceous rocks are treated as undifferentiated. These rocks are equivalent to the Cheyenne Sandstone, the Kiowa Shale, and the Dakota Formation. The lithologic character of these rocks consists of interbedded shale, clay, sandstone, and siltstone. The thickness of Lower Cretaceous rocks ranges from about 120 to about 460 feet (Meyer and others, 1970).

The Upper Cretaceous Series contains the Graneros Shale, the Greenhorn Limestone, and the Carlile Shale (fig. 3). The lithologic character of these rocks consists of massive cream-colored chalky limestone and gray to black clayey and chalky shale. They also contain thin limestone beds and some sandstone (Meyer and others, 1970).

Several pre-Tertiary drainage patterns can be ob- 


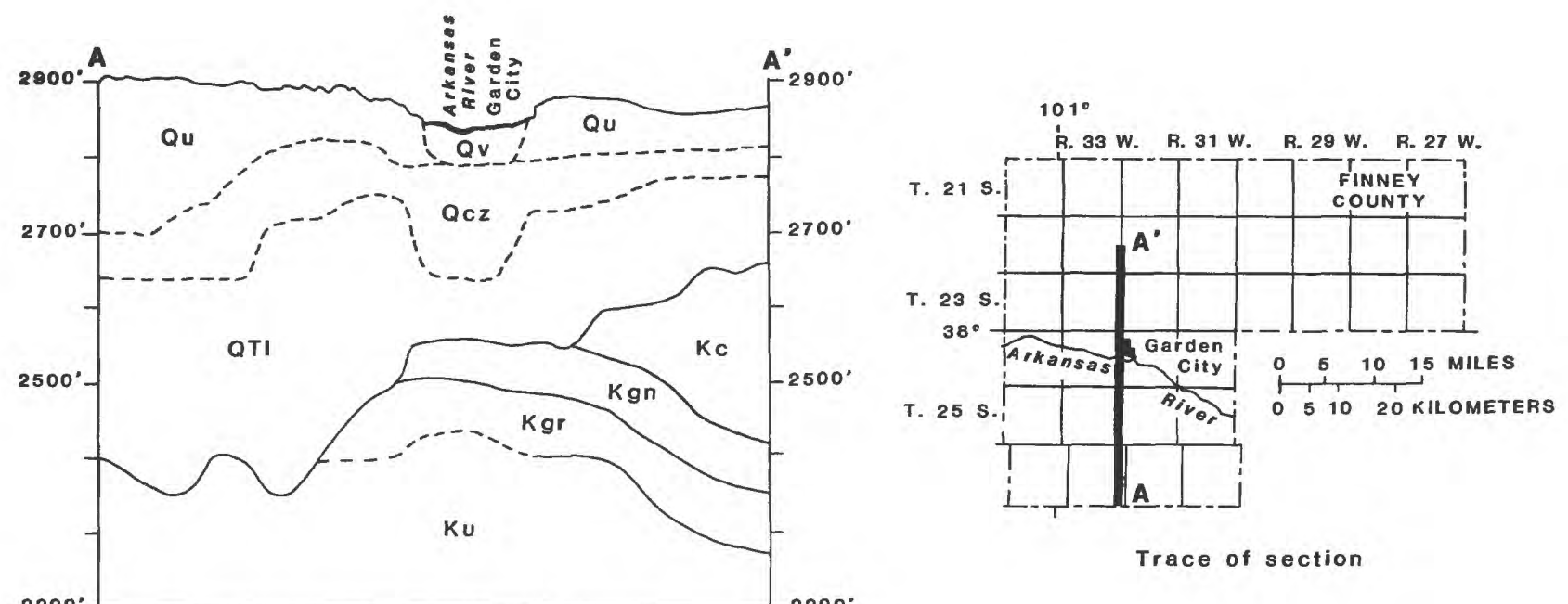

VERTICAL SCALE GREATLY EXAGGERATED DATUM IS SEA LEVEL

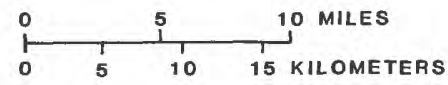

EXPLANATION
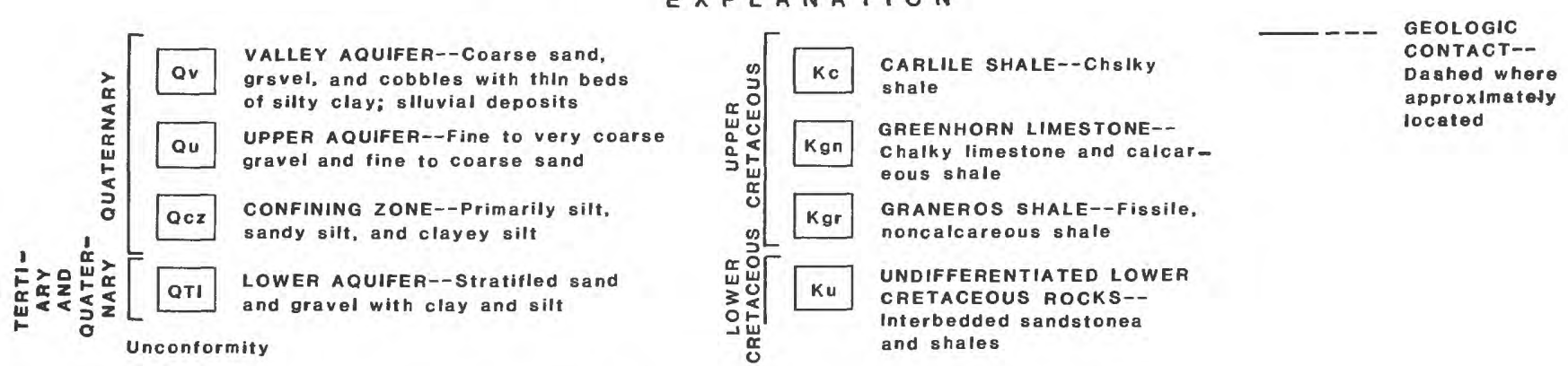

Figure 3. Hydrogeologic section in Finney County.

served on the bedrock surface (fig. 4). Contours on the bedrock surface indicate that a major ancestral valley trended from the northwestern to the southeastern corner of the study area. In addition, an ancient tributary extended northward near Garden City. Several other minor southeast-trending pre-Tertiary drainage systems can be detected on the bedrock surface.

The Bear Creek fault zone is the major structural feature on the bedrock surface. It consists of a steeply dipping monocline, downthrown on the east side (fig. 4). The maximum displacement of the fault is about 250 feet. The faulting probably is due to dissolution of salt evaporites from the bedrock by ground water, which has led eventually to structural collapse and vertical displacement. Furthermore, the Bear Creek fault interrupts the major ancestral valley on the bedrock surface, indicating that the fault is of a younger age than other bedrock-surface features.

The Bear Creek fault zone separates the phase-I and phase-II study areas. West of the fault (phase I), the geohydrology near the river is dominated by alluvial sediments that have filled a relatively shallow bedrock trough.
These sediments gradually thicken to the east as the bedrock altitude decreases near the fault. From west to east across the Bear Creek fault zone there is a difference in saturated thickness of more than 200 feet. However, it is not possible to map with confidence the saturated thickness within the zone. Accordingly, the Bear Creek fault is referenced as a "zone" because it is difficult to locate where the hydrologic effects owing to the fault begin and end. East of the fault (phase II), thick alluvial sediments form a multilayered aquifer system of Miocene and Pleistocene sediments. The aquifer system is characterized by significant components of vertical flow between the layers and limited interaction with surface water.

\section{Undifferentiated Miocene and Pleistocene Deposits}

The unconsolidated Miocene and Pleistocene deposits are the major water-bearing sediments and are the source for almost all ground-water supplies in the study area. These deposits either are correlated with the Miocene Ogallala Formation or are assigned a Pleistocene age. 


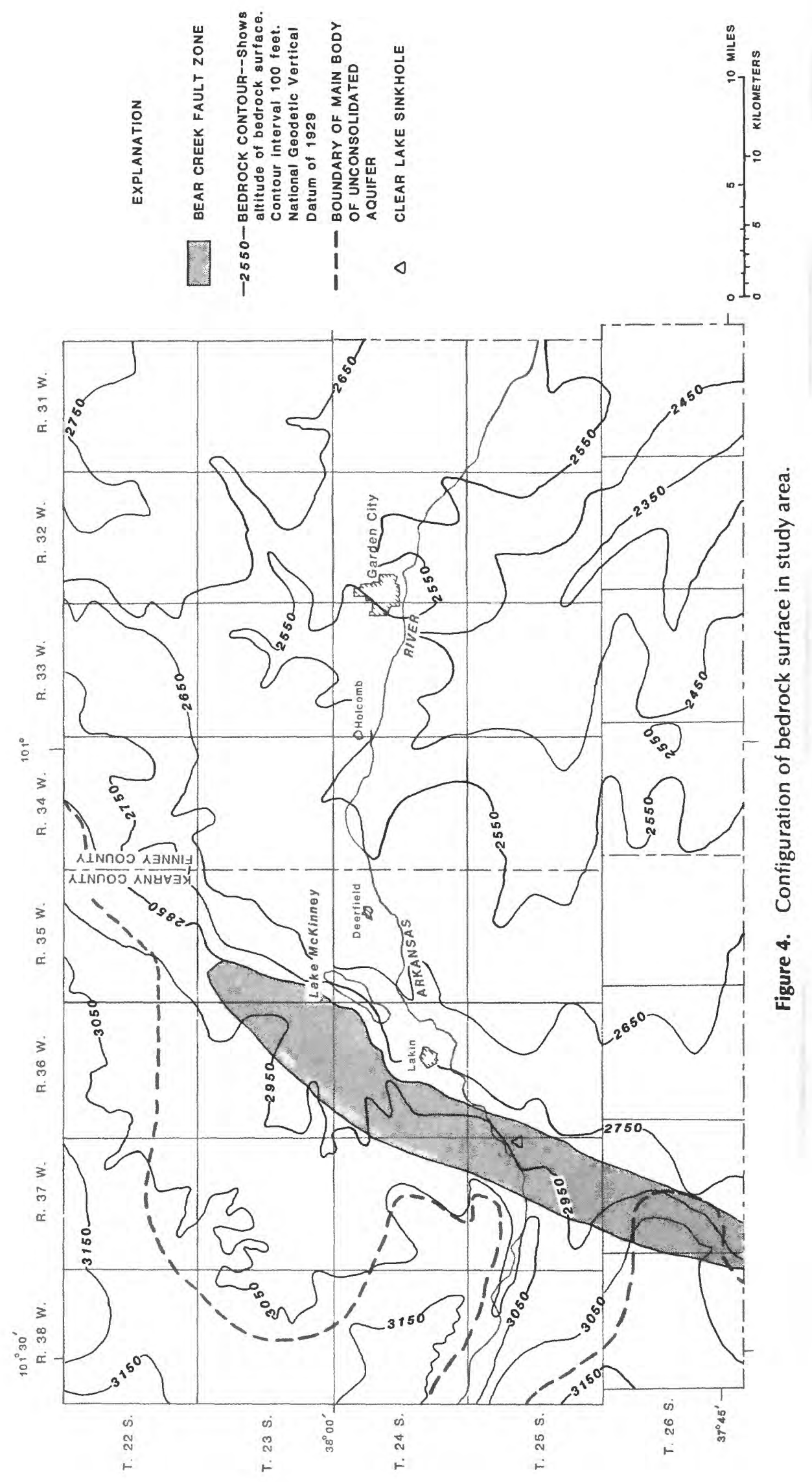


The Ogallala Formation consists of tan, reddish-tan, and yellow sediments. These sediments contain poorly sorted layers of silt, clay, sand, gravel, and caliche, but individual beds or lenses are not continuous over wide areas (Meyer and others, 1970).

The Ogallala Formation was deposited upon the Cretaceous bedrock by eastward- and southeastward-flowing streams. The sediments consist of erosional debris from the Rocky Mountains and sedimentary rocks from southeastern Colorado and western Kansas. The sediments were deposited as alluvial fills that eventually overtopped the valleys. The sedimentation continued by shifting, meandering streams, which caused the Ogallala Formation to be a heterogeneous assortment of alluvial sediments. The thickness of the Ogallala ranges from near zero to about 300 feet.

During Pleistocene time, streams cut broad and shallow valleys through the Ogallala Formation. Afterward, the valleys were filled and overtopped by Pleistocene sediments. The Pleistocene deposits are a mixture of coarse-grained channel deposits and fine-grained stream and lake deposits, and thickness of the deposits ranges from near zero to about 300 feet (Meyer and others, 1970).

The lower deposits of Pleistocene age consist primarily of tan to reddish-brown calcareous silt, sandy silt, and clayey silt. In some places the sediments are interbedded with gray to almost white caliche beds (Meyer and others, 1970). Generally, lying above the fine-grained sediments are deposits of fine to coarse gravel and coarse sand containing fine to medium sand interbedded with thin silt deposits. In most places, the deposits do not contain caliche as does the Ogallala Formation (Meyer and others, 1970).

Because of the similarity in lithology, the contact between the Ogallala Formation and the overlying Pleistocene deposits is difficult to determine. Therefore, the Ogallala Formation and the Pleistocene deposits were not differentiated in this study but were grouped into an aquifer with similar hydrologic characteristics.

\section{Upper Pleistocene and Holocene Deposits}

Loess overlies the Pleistocene deposits north of the Arkansas River in the study area. It consists of a pale yellowish-brown calcareous silt loam. The thickness of the loess ranges from 5 to 30 feet and averages about 12 feet for Finney County (Meyer and others, 1970).

Dune sand is exposed south of the Arkansas River and in a few isolated areas north of the river. It is composed predominantly of fine to medium cross-bedded quartz sand. Additionally, minor amounts of clay and silt are included. The thickness of the dune sand in most areas typically ranges from 20 to 35 feet, but in some places wind action has formed hills as much as $60-$ feet high.
Simonett (1960) suggested the possible sources of the dune sand to be either from terrace deposits or alluvium near the river. In some places, the dune sand overlies the alluvium.

Alluvium of late Pleistocene and Holocene age underlies the flood plain of the river. The Holocene deposits consist of 5 to 10 feet of clay, silt, and fine sand. Underlying the Holocene deposits are Upper Pleistocene deposits of coarse sand, gravel, and cobbles and thin beds of silty clay (Meyer and others, 1970).

The width of the alluvium ranges from 2 miles near the eastern boundary of the study area to 5 miles at Lakin. The thickness of the alluvium ranges from about 40 feet in Finney County to as much as 70 feet in Kearny County.

\section{Arkansas River}

The Arkansas River originates in the Rocky Mountains in central Colorado and flows eastward across Colorado and Kansas. The river is the most important source of surface water in western Kansas. The Arkansas River channel in the phase-II study area is about 45-miles long. The channel gradient averages 7 feet per river mile. Bankto-bank channel widths average less than 30 feet.

\section{Ground Water}

Ground water occurs in five hydrologic units in the study area. They are: (1) the bedrock aquifer (the Lower Cretaceous Series), (2) the lower unconsolidated aquifer (undifferentiated Miocene and Pleistocene deposits, henceforth referred to in this report as the lower aquifer), (3) the confining zone (the lower clays and silts of Pleistocene age), (4) the upper aquifer (the upper sands and gravels of Pleistocene age), and (5) the valley aquifer (the Arkansas River alluvium) (fig. 3).

Water enters the aquifer system from (l) groundwater inflow from the alluvium in the phase-I area, (2) ground-water inflow from the northern boundary, (3) infiltration from precipitation and irrigation water, and (4) seepage from the Arkansas River streambed and irrigation canals.

Water discharges from the aquifer system by means of (1) well pumpage and (2) outflow from the southern and eastern boundaries. Base flow to the river and groundwater evapotranspiration have been practically nonexistent since the 1970's.

\section{Bedrock Aquifer}

The bedrock aquifer consists of the shales and sandstones in the Lower Cretaceous Series. The sandstone lenses are the major source of water. However, as of 1981, few wells tap these sandstone lenses for water. Within the aquifer, water generally flows eastward under 
a hydraulic gradient of about $8 \mathrm{ft} / \mathrm{mi}$ (Jack Kume, U.S. Geological Survey, oral commun., 1981). Data from an aquifer test south of Holcomb indicated that the transmissivity of the bedrock aquifer is $935 \mathrm{ft}^{2} / \mathrm{d}$ and that the storage coefficient is 0.0004 (dimensionless).

Because of a lack of data the Lower Cretaceous is considered bedrock where it is in contact with the Ogallala Formation. In other words, the Lower Cretaceous Series is simulated in this report as a bedrock boundary through which water cannot leave or enter the overlying unconsolidated aquifer system.

\section{Lower Aquifer}

The lower aquifer consists of undifferentiated Miocene and Pleistocene deposits of stratified clay and gravel with clay and silt. This is the principal aquifer and is the source for virtually all ground-water supplies in the study area. The lower aquifer commonly yields more than $1,000 \mathrm{gal} / \mathrm{min}$ of water to large-capacity wells. However, sites for large-capacity wells are usually selected after extensive test drilling to locate the most sand and gravel. Within the aquifer, water generally flows eastward and southeastward under a hydraulic gradient averaging about $8 \mathrm{ft} / \mathrm{mi}$. Values of hydraulic conductivity for the lower aquifer (from previous and ongoing studies in the area) range from 80 to $150 \mathrm{ft} / \mathrm{d}$, and the storage coefficient ranges from 0.05 to 0.0006 (dimensionless).

The lower aquifer is mostly confined south of the Arkansas River. On the other hand, north of the river, water levels in wells in the lower aquifer during 1981 were below the confining material and thus indicated water-table or unconfined conditions.

\section{Confining Zone}

Above the lower aquifer are Lower Pleistocene deposits that serve as a moderately permeable confining zone. This zone consists of lenses of silt, sandy silt, and clayey silt that are interbedded with sand and caliche lenses (Meyer and others, 1970). Accordingly, these deposits confine the lower aquifer south of the river and retard the vertical movement of water to and from overlying aquifers. The confining zone ranges from near zero to about 200-feet thick, but individual clay and silt lenses are difficult to correlate from one area to the next.

The confining zone does not yield significant amounts of water to large-capacity wells, but an adequate supply of water can be obtained in some of the sand lenses for domestic and stock supplies. Although data are scarce within the confining zone, water flows eastward under a hydraulic gradient of about $10 \mathrm{ft} / \mathrm{mi}$. Data from two aquifer tests indicate that the vertical hydraulic conductivity ranges from $1 \times 10^{-2}$ to $1 \times 10^{-4} \mathrm{ft} / \mathrm{d}$.

\section{Upper Aquifer}

South of the Arkansas River valley, a water-table aquifer overlies the confining zone. The upper aquifer consists of fine to very coarse gravel and fine to coarse sand of Pleistocene age. Data were not available to determine the direction of flow and the hydraulic gradient of the upper aquifer. Values of hydraulic conductivity for the upper aquifer (from previous studies in the area) range from 82 to $200 \mathrm{ft} / \mathrm{d}$. Values of specific yield are not known. The upper aquifer has been dewatered north of the Arkansas River.

Near the southern boundary of the study area, some wells are screened in the upper aquifer, and others are screened in the lower aquifer. Measurements of water levels in wells show that the potentiometric surfaces of the upper and lower aquifers are similar. Fluctuations of water levels in wells screened in the upper and lower aquifers are also similar. Since the thickness of the confining zone is small, the upper and lower aquifers are hydraulically connected, and the vertical movement of water is high.

Near the river valley, the confining zone is thicker, and the saturated thickness of the upper aquifer is smaller (fig. 3). A break in hydraulic connection between the upper and lower aquifers and less vertical movement of water through the confining zone are indicated by large differences in the potentiometric surfaces of the two aquifers. Significant differences also occur in the seasonal fluctuations of the potentiometric surfaces of the upper and lower aquifers because of pumpage from the lower aquifer. Only a few stock and domestic wells are screened in the upper aquifer.

\section{Valley Aquifer}

The valley aquifer of late Pleistocene and Holocene age underlies the Arkansas River valley. The alluvial deposits consist of poorly sorted coarse sand, gravel, and cobbles and thin beds of silty clay. Within the valley aquifer, water generally flows eastward and southeastward under a hydraulic gradient that averages about $8 \mathrm{ft} / \mathrm{mi}$. Data from aquifer tests in Kearny County show that the average hydraulic conductivity is $500 \mathrm{ft} / \mathrm{d}$ and that the specific yield is 0.14 (Gutentag, Lobmeyer, and McGovern, 1972). Data from Finney County show that the hydraulic conductivity ranges from 80 to $350 \mathrm{ft} / \mathrm{d}$. The valley aquifer and the upper aquifer to the south are hydraulically connected horizontally. During the 1970's, water from the valley aquifer leaked through the confining zone to the lower aquifer because of depressed hydraulic heads in the lower aquifer.

The valley aquifer can yield a significant amount of water to large-capacity wells in the western part of the study area. In the eastern part, however, decreases 
in saturated thickness and poor water quality have caused many irrigators to abandon their shallow irrigation wells.

\section{Surface Water}

\section{Arkansas River}

For more than a century, irrigators in Kansas have depended upon the Arkansas River for irrigation. Since 1946 , the delivery of river water has been regulated by John Martin Reservoir near Lamar, Colo. The reservoir was built for the purpose of controlling floods and contributing to the development of water resources within the Arkansas River basin. The reservoir supplies water to the Arkansas River as far downstream as the Kearny-Finney County line.

Historically, the river derived its flow from groundwater discharge in areas of high water table and from flow from upstream. But by the early 1900's, Slichter (1906) reported that the river was frequently dry from June until October. During the 1950's and 1960's, the annual discharge of the river at Garden City decreased

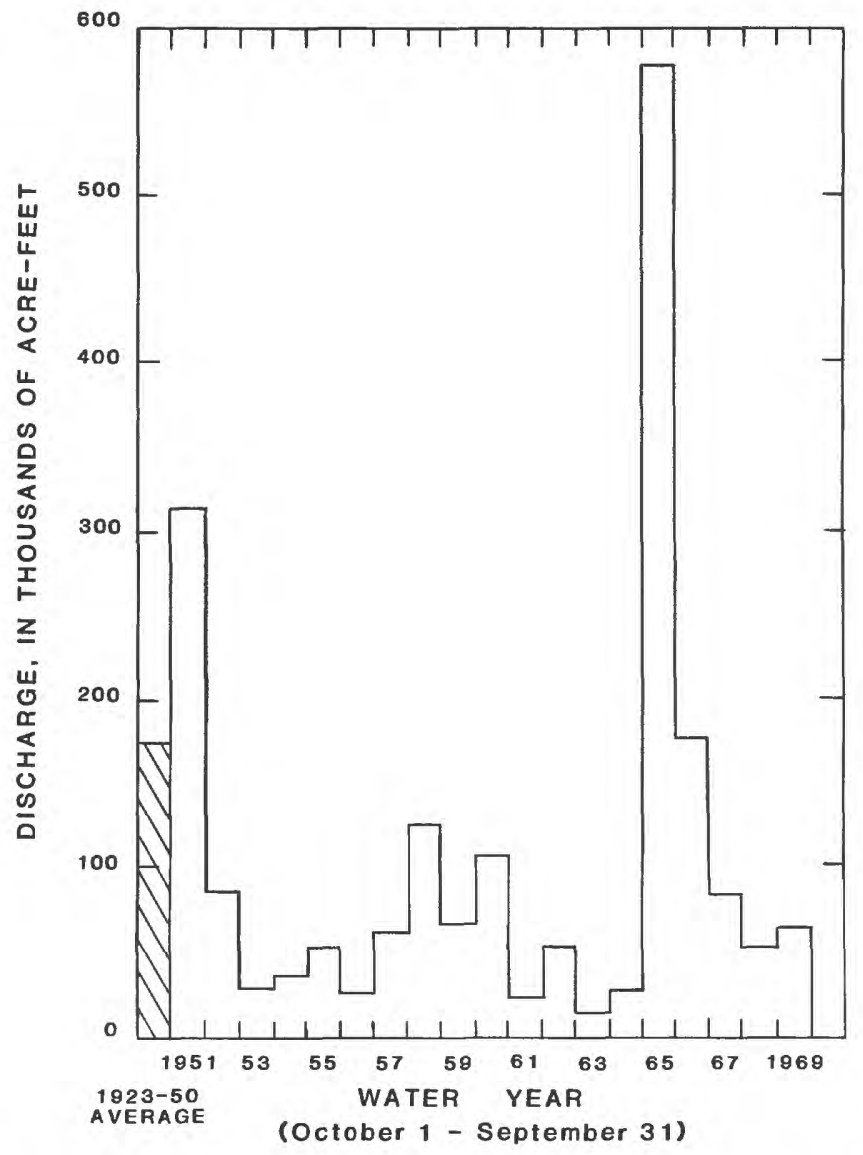

Figure 5. Annual discharge of Arkansas River at Garden City, 1923-50 average and 1951-69. from the 1923-50 average, which was 176,000 acre-ft/yr (fig. 5). During 1970, the streamflow gage at Garden City was changed from measuring daily discharge to flood discharge only. During the late 1970's, the Arkansas River at Lakin was dry all year except for flood flows and periods of time when John Martin Reservoir released water for irrigation (fig. 6). The decrease in Arkansas River streamflow can be attributed to the decrease in ground-water discharge to the river due to a declining water table in the valley aquifer and to decreased flow from upstream in the phase-I study area.

\section{Irrigation Canals}

During 1940, 11 irrigation canals diverted Arkansas River water to irrigated cropland in western Kansas, but only 6 were still in existence during 1981. As of 1981, five of the six irrigation canals diverted water in the study area (fig. 7).

Because river discharge decreased during the 1970 's, the amount of water diverted from the Arkansas River has decreased also (fig. 8). Furthermore, some canals have not been able to divert any water during some years because of insufficient flow in the river. Therefore, the canals must use a rotation system in receiving river water from John Martin Reservoir. The Division of Water Resources of the Kansas State Board of Agriculture regulates the rationing of river water.

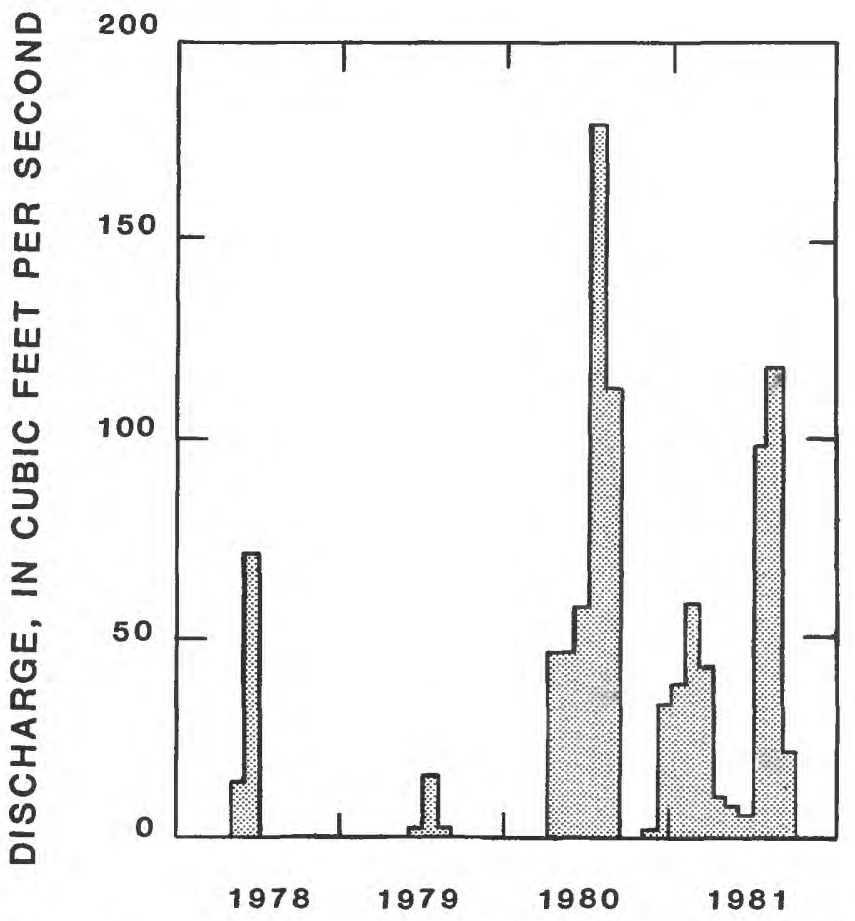

Figure 6. Mean monthly discharge of Arkansas River at Lakin, 1978-81. 


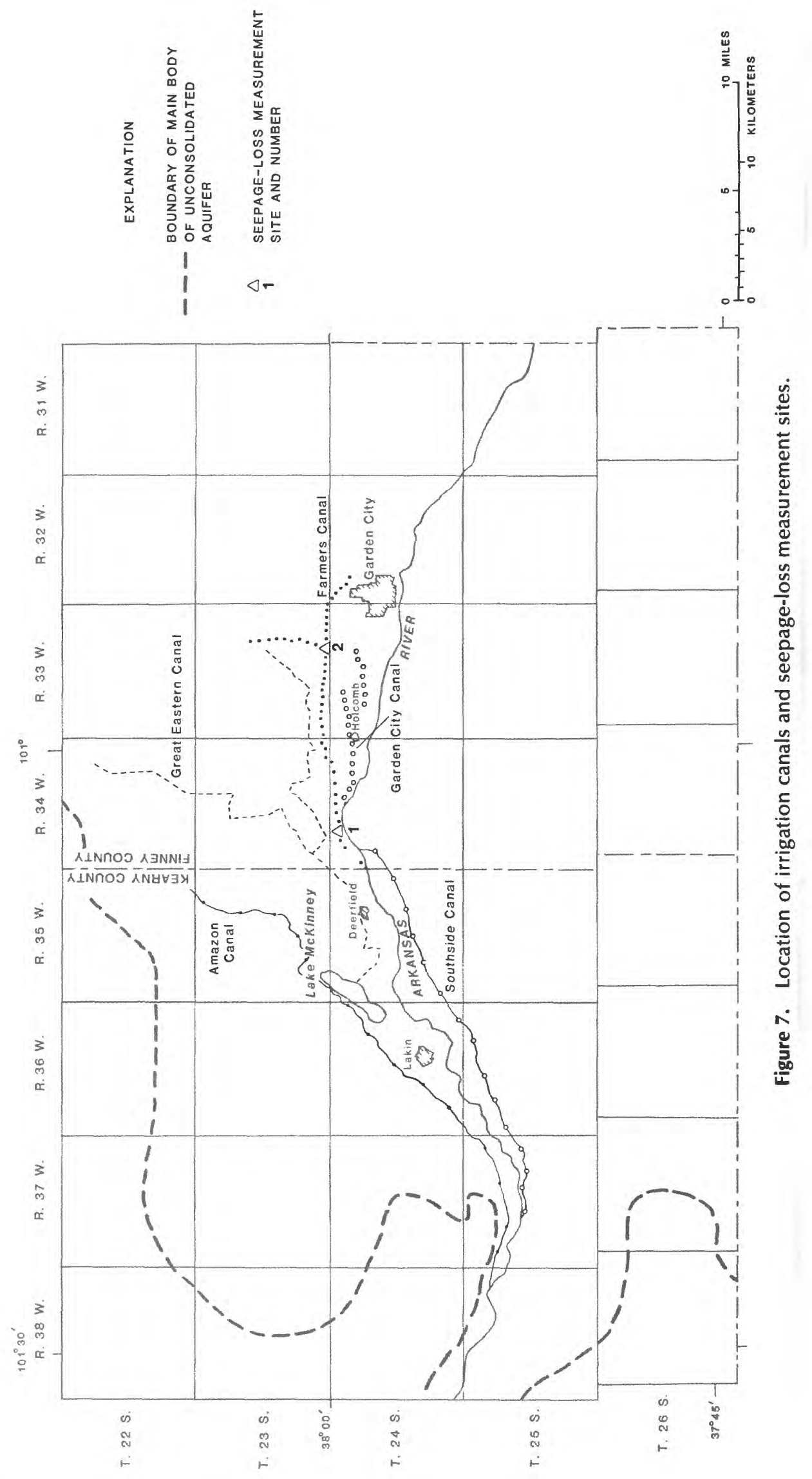




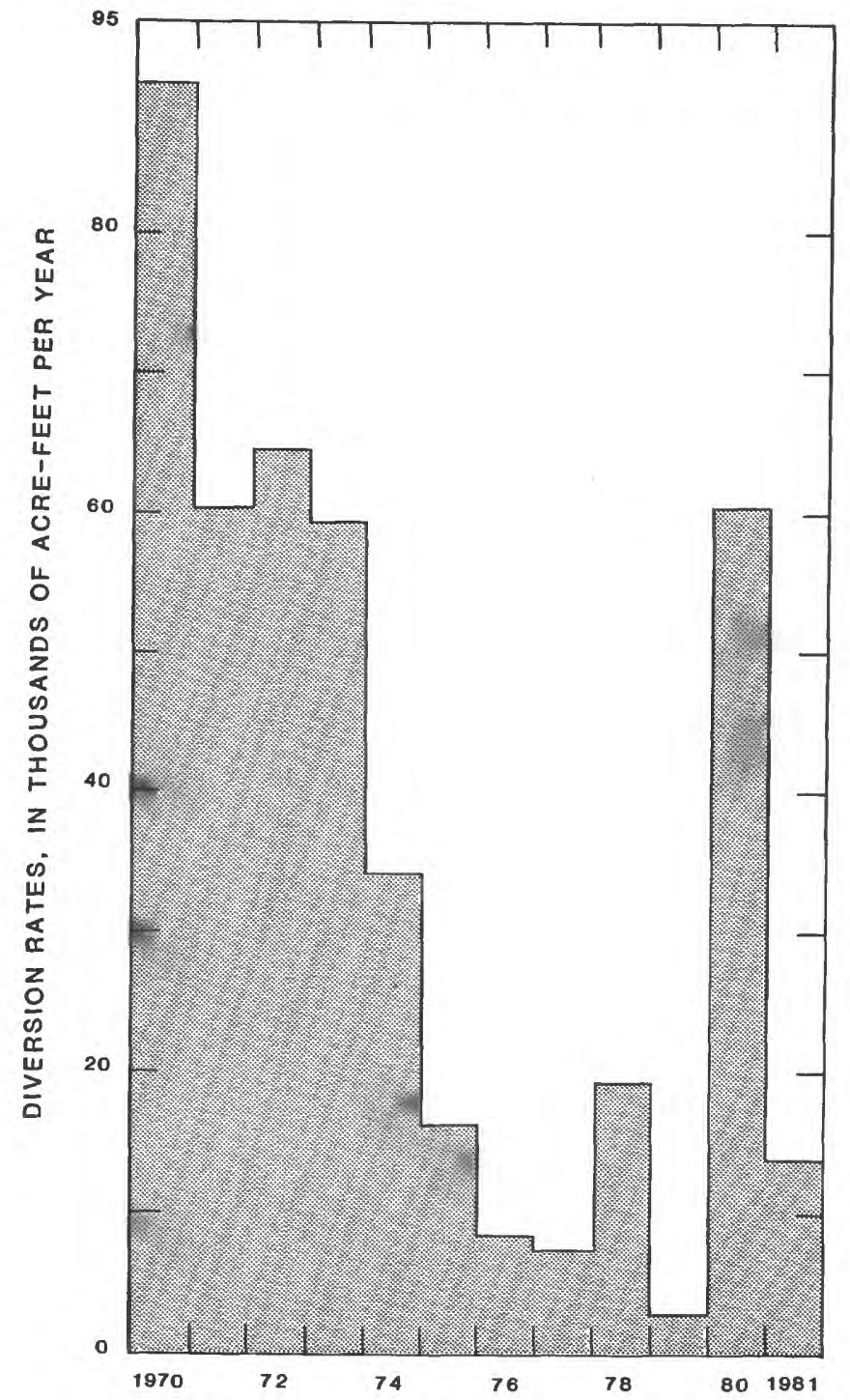

Figure 8. Annual diversion rates by irrigation canals, 1970-81 (includes Amazon, Great Eastern, Southside, Farmers, and Garden City canals).

\section{USE OF GROUND WATER}

\section{Irrigation}

Agriculture is the principal user of water in the study area. During 1980, 320,000 acres of corn, grain sorghum, alfalfa, and wheat were irrigated by ground water or by surface water from the Arkansas River. During that same year, approximately 2,900 wells (fig. 9) pumped an estimated 738,000 acre-feet of water (Lindgren, 1982) for irrigation to supplement precipitation (17 to $19 \mathrm{in} / \mathrm{yr}$ ). Without irrigation, farmers are limited to growing crops such as wheat or sorghum biennially, leaving the land fallow during the off year to accumulate soil moisture. Thus, irrigation is very important to the economy of the area.
The demand for irrigation increased dramatically during the 1950's and 1960's in the Arkansas River valley and north of the river. Most of the demand was met by new irrigation wells (fig. 10) because of the limited and unreliable amount of water available from irrigation canals.

The study area can be separated into three generalized physiographic areas where irrigation occurs: (1) the Arkansas River valley, (2) the high plains, and (3) the sandhills (fig. 11). Names of these physiographic areas are for purposes of this report and only apply to regions within the study area.

\section{Arkansas River Valley}

The flood plain of the Arkansas River valley is flat and characterized by sandy and loamy soil. This soil has a high infiltration capacity and is capable of recharging large amounts of water to the underlying valley aquifer.

Ground-water irrigation in the Arkansas River valley has been in existence since the early 1900's. Before the 1940's, shallow centrifugal-type wells withdrew large amounts of water from the sand and gravel in the alluvium. During the 1960's and 1970's new wells were drilled deeper into the lower aquifer. However, wells commonly were not screened in the valley aquifer because of poor-quality water and decreasing saturated thickness. The increase in water pumped from the lower aquifer has caused leakage from the valley aquifer to the lower aquifer through the confining zone. As a result of leakage to the lower aquifer and reduced streamflow, water-table levels in the valley aquifer have been declining.

\section{High Plains}

The loess-covered high plains north of the river are irrigated primarily by gravity from both irrigation canals and wells. The Finney basin, described by Meyer and others (1970), is part of this area. Irrigation in the high plains has increased steadily since the 1930's. Before the mid-1970's, both the lower and upper aquifers supplied water for irrigation north of the river. But since that time, the upper aquifer has been dewatered north of the river because of the declining potentiometric surface of the lower aquifer. Therefore, the upper aquifer is no longer supplying water for irrigation. A further discussion of the dewatering of the upper aquifer can be found in the section entitled "Historic Hydrologic Response."

\section{Sandhills}

The physiographic area south of the Arkansas River valley is characterized by hilly, fine, loose sand. This area is frequently called the "sandhills." The sandhills soil has a high infiltration capacity that enables high recharge 


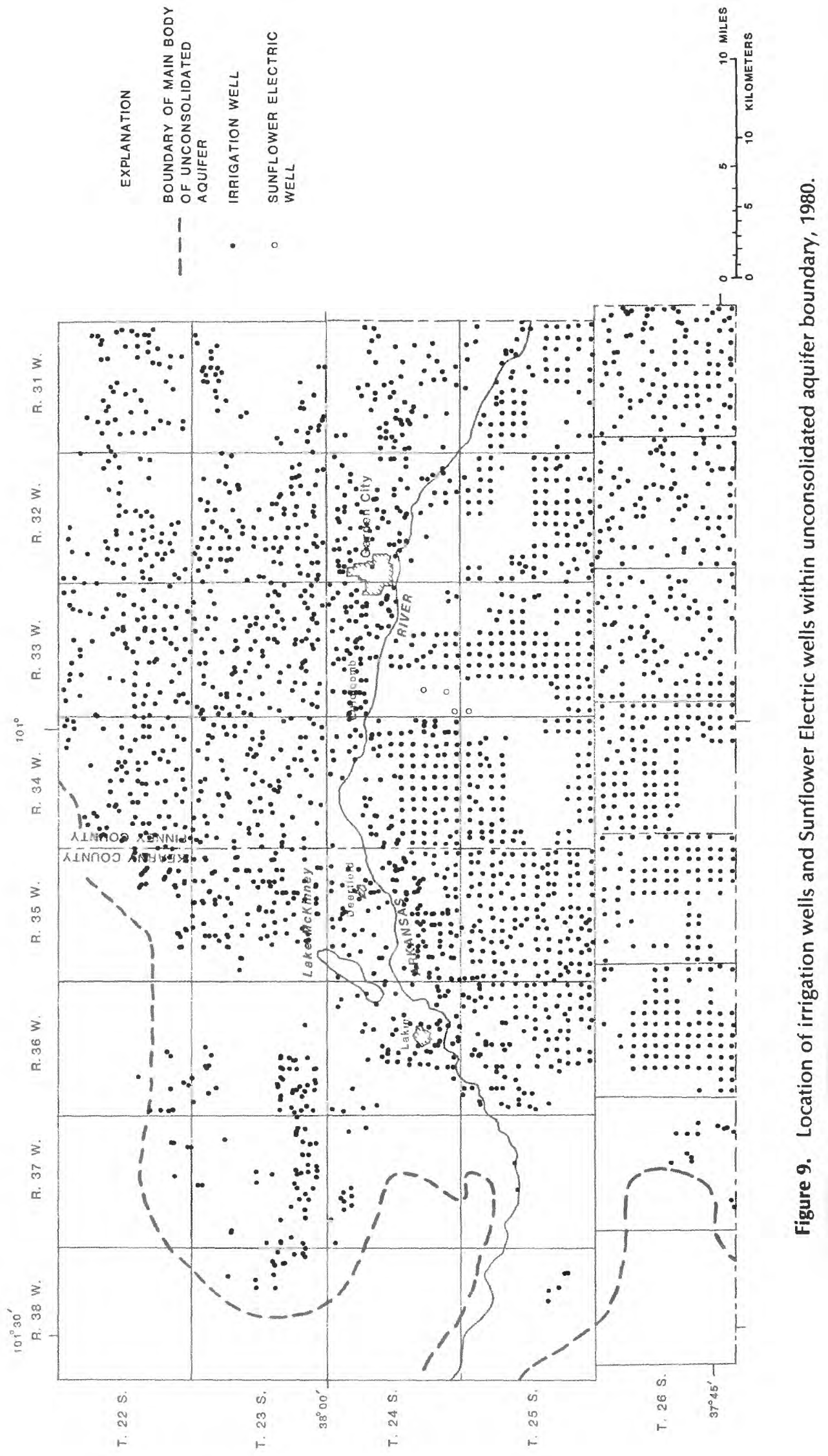




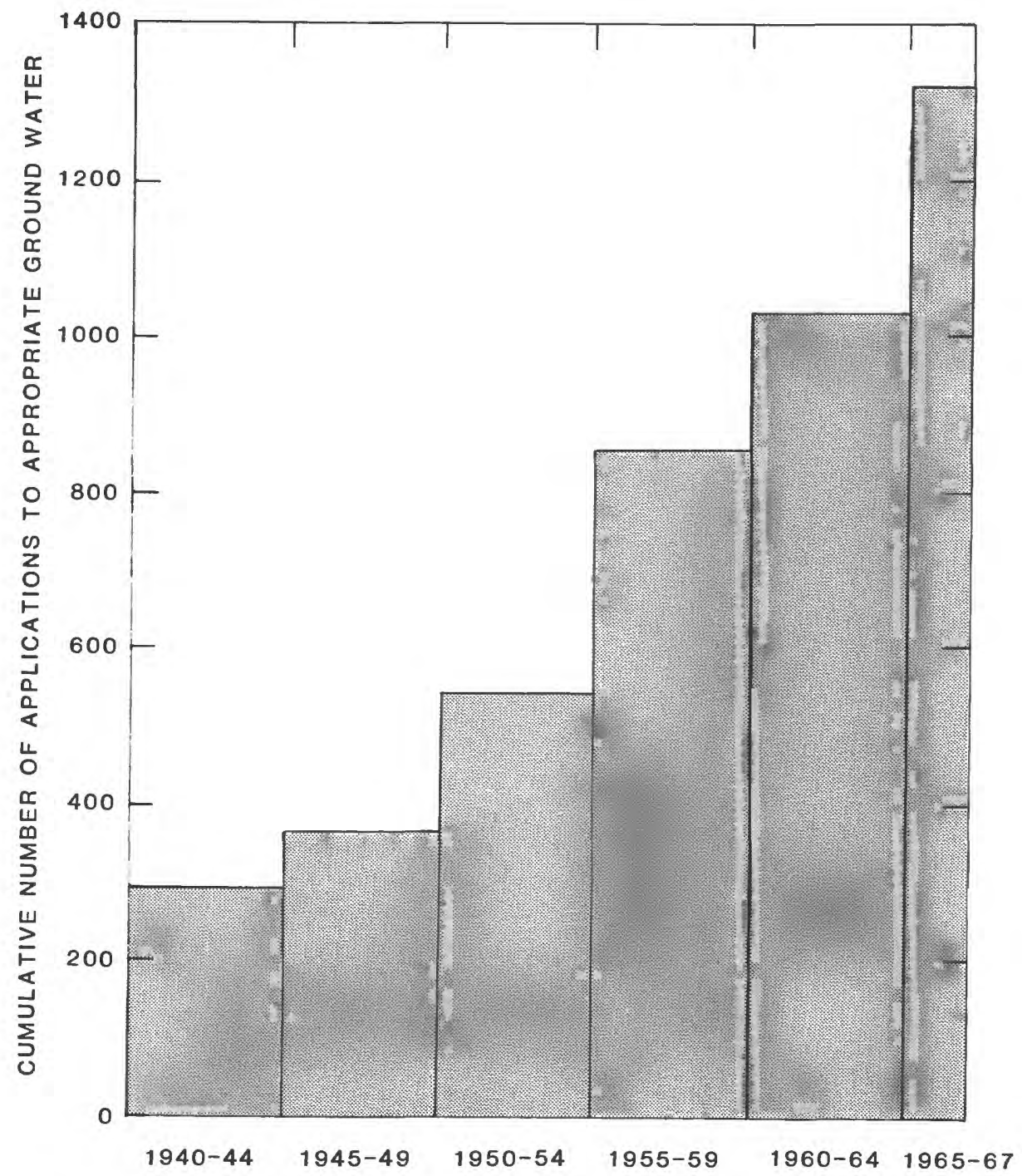

Figure 10. Cumulative number of applications to appropriate ground water in Kearny and Finney Counties, 1940-67.

from precipitation and irrigation to the underlying upper aquifer.

Wells in the sandhills pump water from the lower aquifer, with a minor amount coming from the upper aquifer. Center-pivot systems, which irrigate a circular parcel of land, are used in the sandhills. The hilly topography makes gravity-type systems impractical. This fact is important because most of the irrigation in the sandhilis was developed during the 1970's after center-pivot systems became practical.

\section{Industry}

During 1980, Sunflower Electric and Iowa Beef Packers began construction of their plants near Holcomb. Sunflower Electric is a coal-fired, electric-generating plant. Sunflower's long-range plan for the plant is three generating units with a total capacity of 1,000 megawatts (net). A plant of this size would require approximately 14,500 acre-feet of water per year. But as of 1981 , the Kansas State Board of Agriculture, Division of Water Resources, has approved the water rights for only one generating unit (200-300 megawatts, net) or a total of 4,390 acre- $\mathrm{ft} / \mathrm{yr}$ of ground water.

Most of the water used by the plant is evaporated to facilitate condenser cooling, with the remainder being used for boiler make-up, ash-sluicing, and sulfur-removal processes. The plant plans on obtaining 80 percent of the required water from the lower aquifer and 20 percent from the bedrock aquifer.

Iowa Beef Packers is a beef-packing plant that expects to employ 2,000 workers and slaughter 4,000 head of beef daily by 1982 . Iowa Beef Packers purchased 1,920 acres of land with existing water rights (a legal right to 


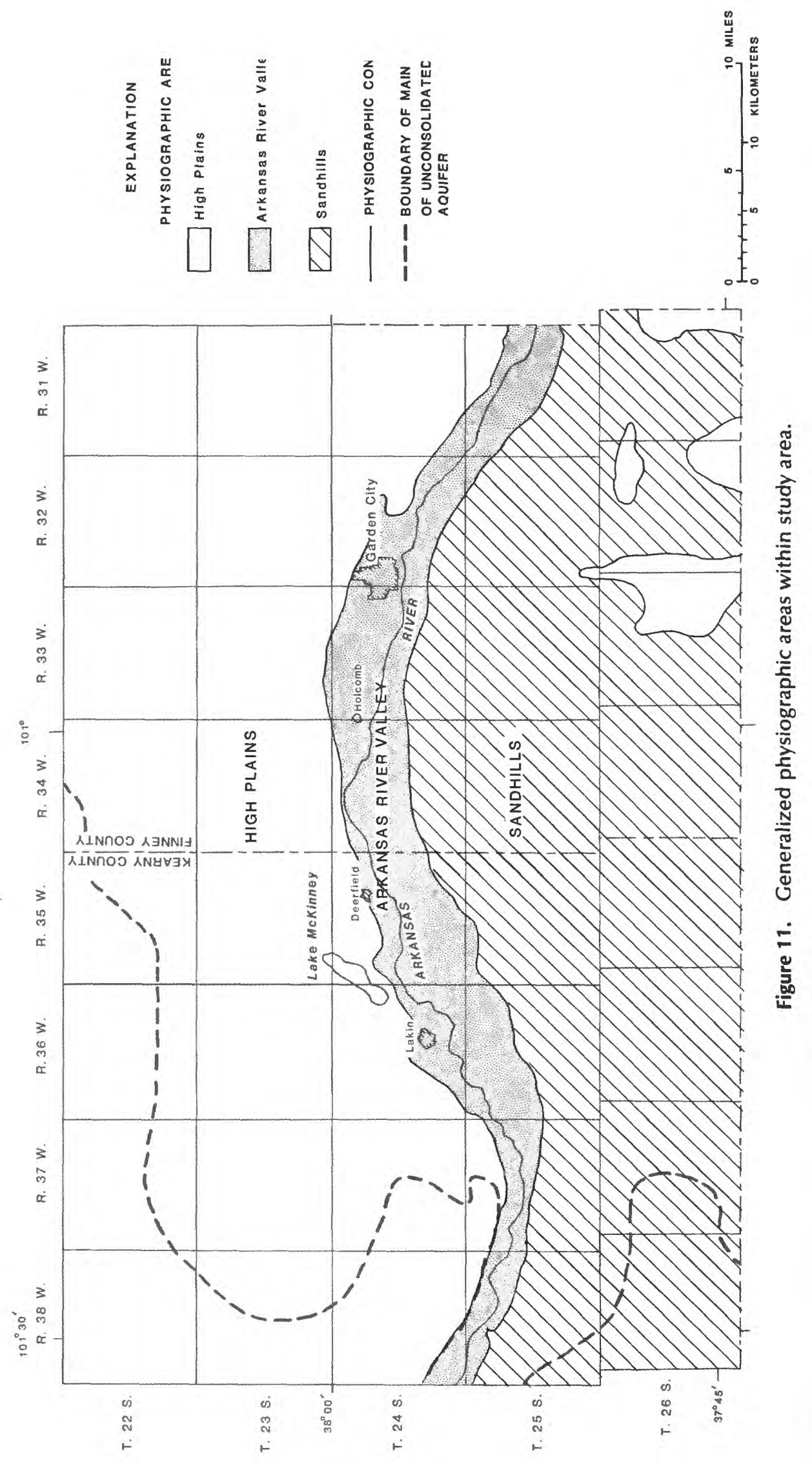


use water) for their water needs. Wells will pump water from the lower aquifer and transport it to the packing plant for use in cleaning carcasses. The plant then will return 85 to 90 percent of the waste water to the land so that it can be used for irrigation. The water right dictates that the maximum amount of water used by Iowa Beef Packers is not to exceed 3,264 acre-ft/yr.

\section{Municipal}

The cities of Lakin, Deerfield, Holcomb, and Garden City have public-water systems supplied by water pumped from the lower aquifer. The total amount of water reportedly used by these cities during 1980 was 7,200 acre-feet.

\section{HISTORIC HYDROLOGIC RESPONSE}

Since the 1960's, the unconsolidated aquifer system has been responding to a period of decreased flow in the Arkansas River (recharge) and increased use of ground water for irrigation (discharge). The decrease in Arkansas River streamflow has occurred because of (1) a decrease in ground-water discharge to the river owing to a declining water table in the valley aquifer, and (2) decreased flow from the phase-I study area. The water-level decline observed in wells completed in the valley aquifer can be attributed to decreased recharge from the Arkansas River and increased leakage downward to the lower aquifer. Leakage downward from the valley and upper aquifers has increased because of increased irrigation pumpage from the lower aquifer in the study area. Much of the upper aquifer has been dewatered north of the Arkansas River, resulting in an increased rate of decline in hydraulic heads in the lower aquifer on the high plains beginning in the mid-1970's. With a limited supply of water, the effect of less recharge, coupled with greater discharge, has been a decrease of ground water in storage.

Hydrologic observations of the unconsolidated aquifer and streamflow response to changes in recharge and discharge were made in the study area as early as 1904. The streamflow-gaging station and observation-well networks monitored for this study are shown in figure 12.

\section{Recharge}

Sources of recharge to the aquifer system are infiltration from precipitation and irrigation water, seepage from the Arkansas River and irrigation canals, and subsurface inflow at the boundaries of the study area. This section will describe these sources.

\section{Infiltration from Precipitation and Irrigation Water}

The 1951-80 long-term average annual precipitation at Garden City (18.2 inches) has been near normal (18.9 inches). The 1970-80 short-term average annual precipitation was 17.6 inches (fig. 13), however, compared to the 18.9 inches of normal precipitation (1941-70) at Garden City. Fortunately, 68 percent of the annual precipitation falls within the May-to-September growing season. But, when dry years occur, they often are accompanied by hot summers, and irrigators increase pumpage of ground water to offset decreases in precipitation and increases in evapotranspiration. During 1980, for example, comparatively high summer temperatures and low precipitation resulted in a high consumptive-irrigation requirement (the amount of irrigation water, in addition to precipitation, required to meet the physiological requirements of growing crops) and increased withdrawal of ground water for irrigation (Lindgren, 1982).

Recharge from return flow of irrigation water was calculated by the soil-zone model (see sections entitled "Transient Model" and "Pumpage").

\section{Arkansas River Seepage}

The exchange of water between the Arkansas River and the valley aquifer occurs through the streambed. The rate and direction of flow through the streambed depends on the hydraulic conductivity of the streambed and the hydraulic gradient between the river and the water table in the valley aquifer. The direction of flow along the hydraulic gradient is from areas of relatively high hydraulic head to areas of relatively low hydraulic head. A stream that loses water to the aquifer is called a "losing stream." A stream that receives flow from the aquifer is called a "gaining stream."

Since 1923 (beginning of annual records), the Arkansas River has been a losing stream in the study area. From 1923-70 the Arkansas River gained and lost flow in about equal proportions as it passed through Hamilton and Kearny Counties. Most of the loss (recharge to the valley aquifer) occurred in Finney County. During the 1970's the Arkansas River also was losing flow throughout most of Kearny County. By the late 1970's, the Arkansas River was dry most of the time in both Kearny and Finney Counties. This has been due to little or no ground-water discharge to the river because of declines in the water table in the valley aquifer and decreased river flow from upstream.

Large seepage losses occur in the Arkansas River between the Amazon Canal headgate and the Farmers Canal headgate (a distance of 22 miles). Location of the headgates is shown in figure 12 . The monthly volume of river water lost between the two headgates has been 


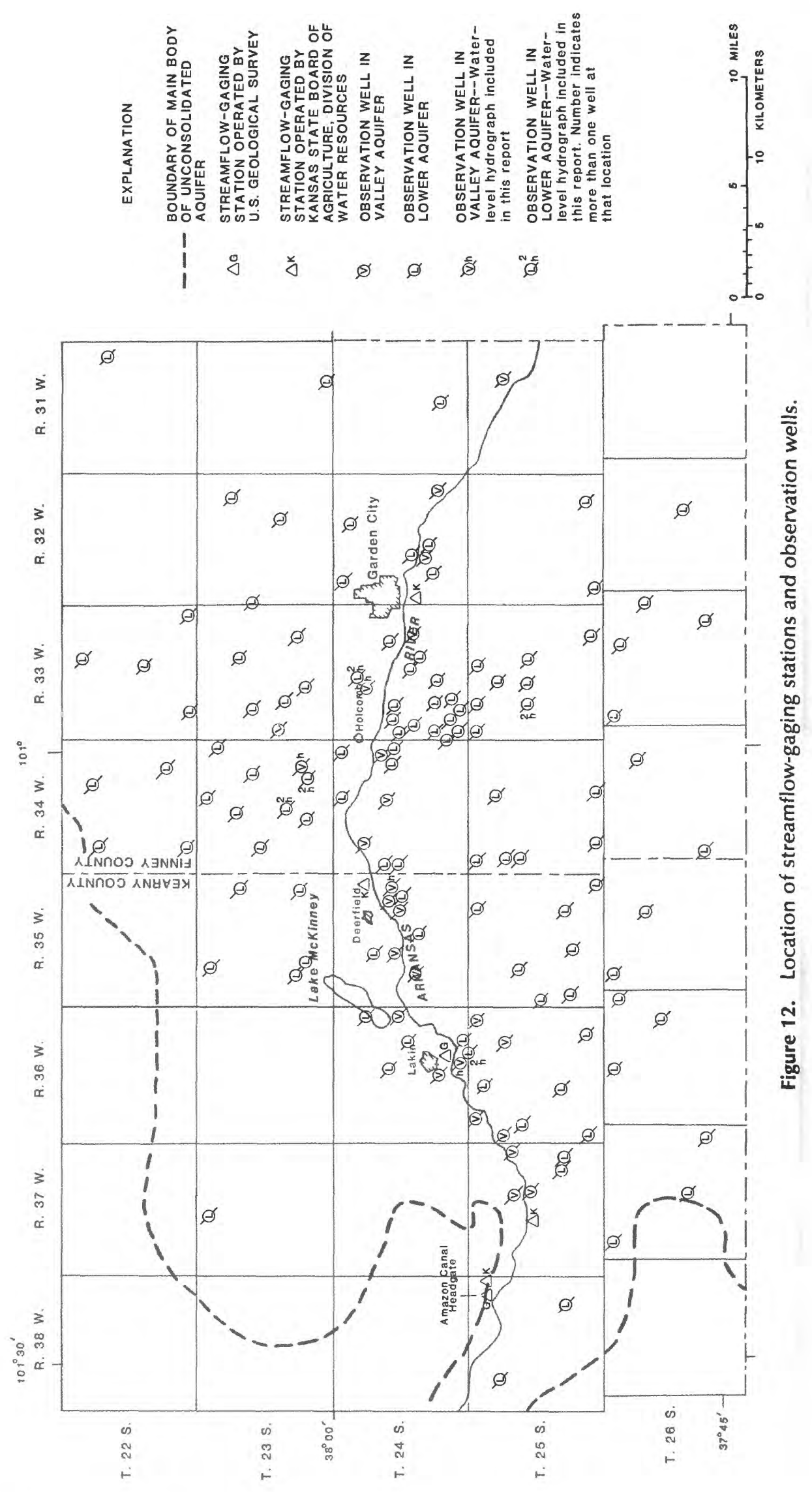




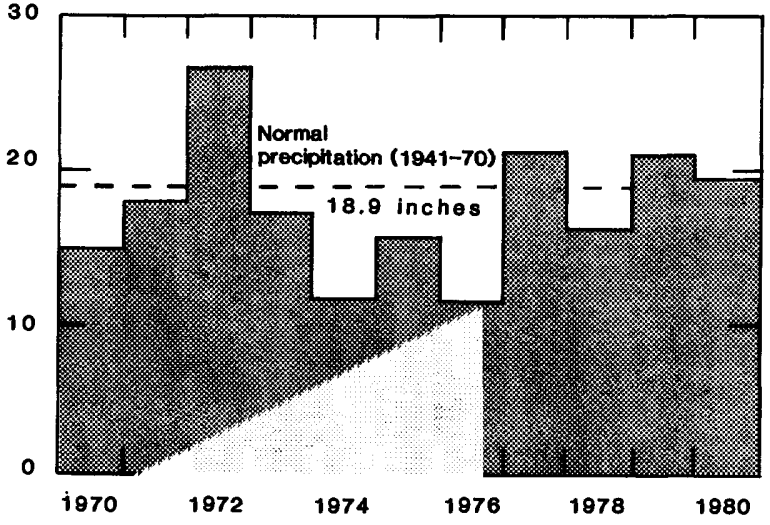

Figure 13. Annual precipitation (1970-80) and normal precipitation (1941-70) at Garden City. as much as 75 percent of the flow at the Amazon Canal headgate (fig. 14). Diversions for Southside Canal were subtracted from the losses.

Seepage losses (infiltration) in an alluvial channel are dependent on many factors, including (1) surface area, depth, and velocity of water in the channel; (2) permeability, moisture distribution, and temperature of the subsurface alluvium; (3) physical quality of the water and length of time the water is available at the land surface; (4) chemical quality of the surface and subsurface water; and (5) structural stability of the porous media (Burkham, 1970). For a dry, structurally stable porous media, infiltration of water generally occurs rapidly when the water is first applied and then gradually decreases as the porous media become saturated. However, the beds of most alluvial channels, including the Arkansas River, are not structurally stable. Some movement and rearrangement of

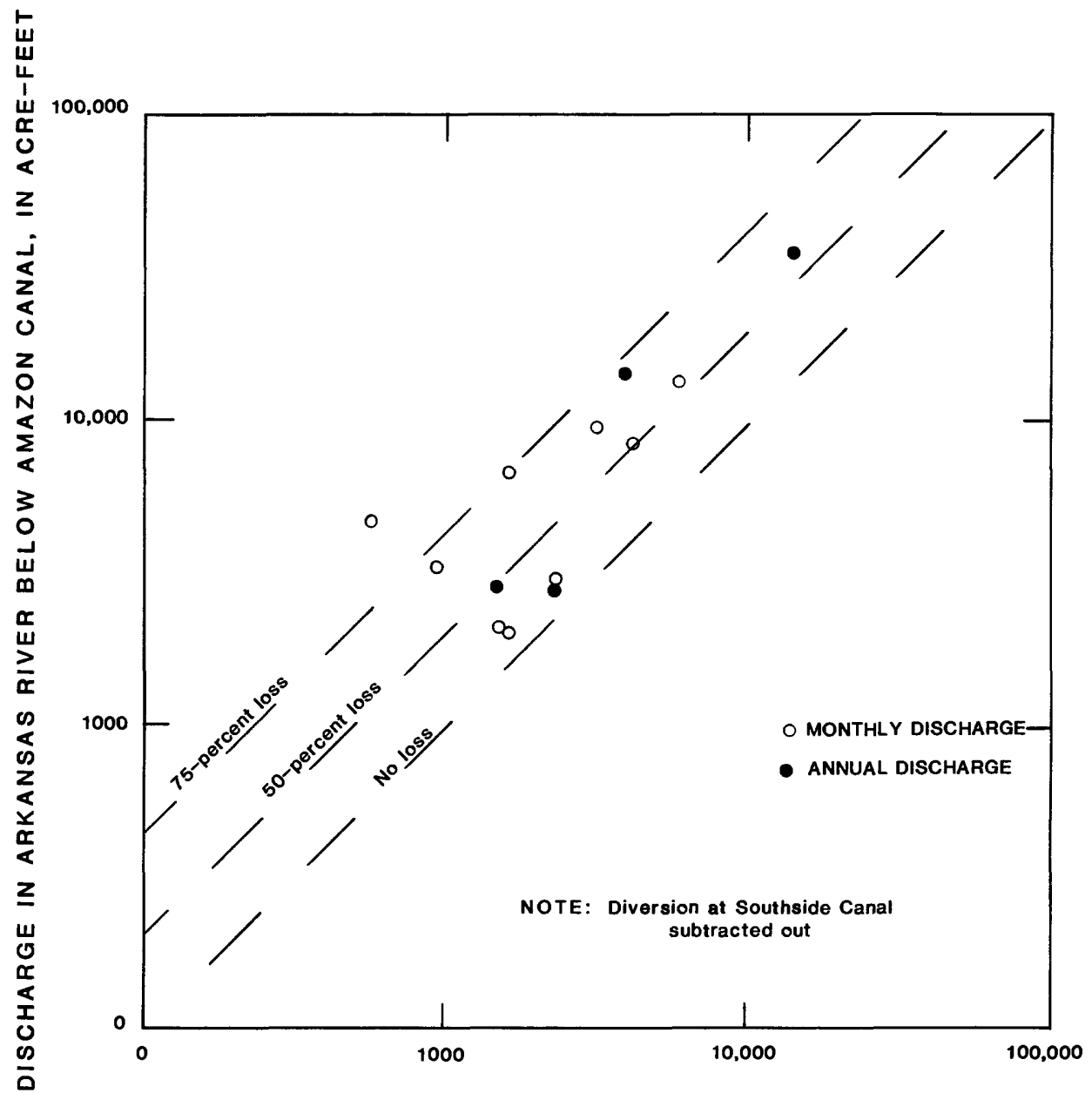

DISCHARGE IN ARKANSAS RIVER AT FARMERS CANAL, IN ACRE-FEET

Figure 14. Comparison of Arkansas River discharge between Amazon Canal and Farmers Canal. 
streambed materials occur during periods of flow, changing the permeability and, therefore, affecting infiltration and seepage losses. At the beginning of a short period of flow, such as a reservoir release, infiltration is probably small because fine materials (silt and clay) left by preceding flows reduce the size and number of pore spaces in the coarse material and develop a thin, inhibiting (to infiltration) layer on the streambed. However, as the fine materials are dislodged and begin to move during the ascending limb of the flow period, infiltration and seepage losses increase. During the recession of the flow, the fine materials in suspension settle out, and infiltration and seepage losses decrease. For streams that are perched above the water table, a decline in infiltration rate and seepage losses also occurs as a result of the filling of the pores in the zone near the streambed by water as infiltration continues.

\section{Irrigation-Canal Seepage}

Water losses also occur as canals transport water from their headgates to irrigated crops. Because irrigation canals have a more silty and clayey bed than the Arkansas River, seepage losses are smaller. In addition, irrigationcanal employees clear debris from the canal to reduce the seepage losses. Debris increases the transport time of the water from the headgates to the irrigated crops, resulting in greater seepage (and evaporation) losses. Also, debris moving along the canal bottom may scour the canal bed, stirring up fine materials and making the bed more porous.

Two seepage-loss measurements were conducted on the Farmers Canal. On July 18, 1980, $125 \mathrm{ft}^{3} / \mathrm{s}$ of water were measured at the Division of Water Resources gage (point 1, fig. 7). Eight miles east of the gage (point 2), $110 \mathrm{ft}^{3} / \mathrm{s}$ of water were measured. In between the two measuring points, $5 \mathrm{ft}^{3} / \mathrm{s}$ of water were being diverted for irrigation. Similarly on July $21,1980,144 \mathrm{ft}^{3} / \mathrm{s}$ of water were measured at point 1 , and $129 \mathrm{ft}^{3} / \mathrm{s}$ were measured at point 2 . In between the measurements, $2 \mathrm{ft}^{3} / \mathrm{s}$ of water were being diverted for irrigation. This is an average loss of $1.4\left(\mathrm{ft}^{3} / \mathrm{s}\right) / \mathrm{mi}$ due to seepage.

\section{Subsurface Inflow}

Subsurface inflow enters the study area from the west and north. The amount of ground water moving into the area is dependent on the cross-sectional area through which the flow is occurring, the hydraulic gradient, and the hydraulic conductivity. As given by the transientmodel mass-balance computations, 17,300 acre-feet of water entered the lower aquifer along the northern boundary of the study area during 1980. The distance from the Arkansas River valley to the northern boundary of the study area was ascertained by determining the radius of influence of a well field pumping at a discharge rate typi- cal for the area and located near the river (see "Model Boundaries"). Subsurface inflow to the upper aquifer during 1980 was simulated in the transient model to be 12,000 acre-feet, as given by mass-balance computations. All of the inflow to the upper aquifer comes from the alluvium in the phase-I study area.

\section{Discharge}

Principal sources of discharge from the aquifer system are (1) ground-water pumpage and (2) subsurface outflow at the boundaries of the study area. Discharge from ground-water evapotranspiration and streamflow was very small during the 1970's.

\section{Pumpage}

Pumpage of ground water for irrigation, municipal, and industrial water use is the largest source of discharge in the study area. Most of the water is used to irrigate crops, such as corn, alfalfa, grain sorghum, and wheat.

Relatively few irrigation wells were present in the study area prior to the 1940's; therefore, pumpage was small. At this time, the unconsolidated aquifer system was in equilibrium or in a steady-state condition (recharge equal to discharge), and hydraulic heads varied little over time. But from 1945-67, the number of well applications to appropriate ground water increased from about 300 to over 1,300 (fig. 10). With the corresponding increase in pumpage, recharge no longer was equal to discharge, and water levels in wells began to decline. During 1980, about 2,900 irrigation wells pumped an estimated 738,000 acrefeet of ground water to irrigate approximately 320,000 acres (Lindgren, 1982). The location of the irrigation wells during 1980 is shown in figure 9 .

\section{Subsurface Outflow}

Subsurface outflow occurs along the eastern and southern boundaries. Similar to inflow, the outflow is dependent on the cross-sectional area through which the flow is occurring, the hydraulic gradient, and the hydraulic conductivity. As given by the transient-model massbalance computations, 28,700 acre-feet of water discharged from the lower aquifer along the eastern and southern boundaries during 1980. Outflow from the upper aquifer along the eastern and southern boundaries during 1980 was simulated in the transient model to be 28,900 acre-feet, as given by mass-balance computations.

The eastern and southern boundaries of the study area coincide with political boundaries (county lines). These boundaries are also outside the radius of influence of a well field pumping at a discharge rate typical for the area and located near the center of the study area in the Arkansas River valley (see "Model Boundaries"). 


\section{Ground-Water Evapotranspiration}

Ground-water evapotranspiration has accounted for little discharge in the study area since the mid-1970's. Previously, phreatophytic growth, such as cottonwoods, willows, salt cedar, and tamerac, grew along the river and extracted water from the valley aquifer. But most of the phreatophytes have died because of the decline of the water table in the valley aquifer (Mark Sexton, Kansas Fish and Game Commission, oral commun., 1981). Water levels in the confining zone and lower aquifer are too deep for phreatophytes to reach.

\section{Streamflow}

Ground-water discharge to the Arkansas River (or base flow) was practically nonexistent in the study area during the 1970's. In order for the Arkansas River to receive discharge from the unconsolidated aquifer system, the water table in the valley aquifer must be above the bottom of the streambed or above the river stage. The Arkansas River has received a net ground-water discharge in the study area (shown by a net annual gain in streamflow between Syracuse and Garden City) only 12 times since 1923; the last time was during the 1959-60 water year (Oct. 1-Sept. 31).

\section{Change In Storage}

A difference in magnitude between the amount of water that enters the aquifer (recharge) and the amount that leaves (discharge) causes a change in the quantity of water in storage. Changes in storage cause changes in hydraulic head in the aquifer (other, less important, possible causes of changes in hydraulic head include changes in atmospheric pressure). Since the 1970's, the unconsolidated aquifer system has responded to an increase in ground-water discharge due to increased irrigation, municipal, and industrial use. At the same time, there has been a decrease in recharge to the valley aquifer because of reduced streamflow in the Arkansas River. The overall result has been a decrease in the amount of water in aquifer storage and a corresponding decline in aquifer heads in the unconsolidated aquifer system. This section will describe the hydraulic-head changes and the corresponding effects on the unconsolidated aquifer system.

\section{Valley Aquifer}

A hydrograph of a representative well (24-35W$13 \mathrm{CCC}$ ), completed in the valley aquifer, shows year-toyear water-table declines since the early 1970's (fig. 15). The declines can be attributed to decreased recharge from the Arkansas River and increased leakage of water downward to the lower aquifer. The altitude of the streambed, marked on the hydrograph, shows that the altitude of the water table has been below the streambed since the early 1970's. Thus, there has been no recent ground-water discharge to the river at this site. When quarterly and monthly measurements are plotted (since 1976), the hydrograph shows water-table rises during the summer. These can be attributed to seepage losses during flow in the river after reservoir releases. Pumpage from the lower aquifer has caused a decline in the potentiometric surface of the lower aquifer, resulting in increased leakage downward from the valley aquifer.

\section{River Stage Versus Ground-Water Levels}

The effect of river stage on water levels in wells in the valley aquifer is demonstrated at Kendall, 9 miles northwest of the fault zone in the phase-I study area (fig. 16). Although the geohydrology in the phase-I study area differs from that in the phase-II study area, the interaction between the river and the valley aquifer is similar for both areas. From 1979 to 1981 , the water level in an observation well 100 feet from the river channel was below the river stage during low flows. Thus, the river was contributing water to the valley aquifer. When high river stages occur, such as during a reservoir release, seepage losses initially increase, resulting in a rise in the

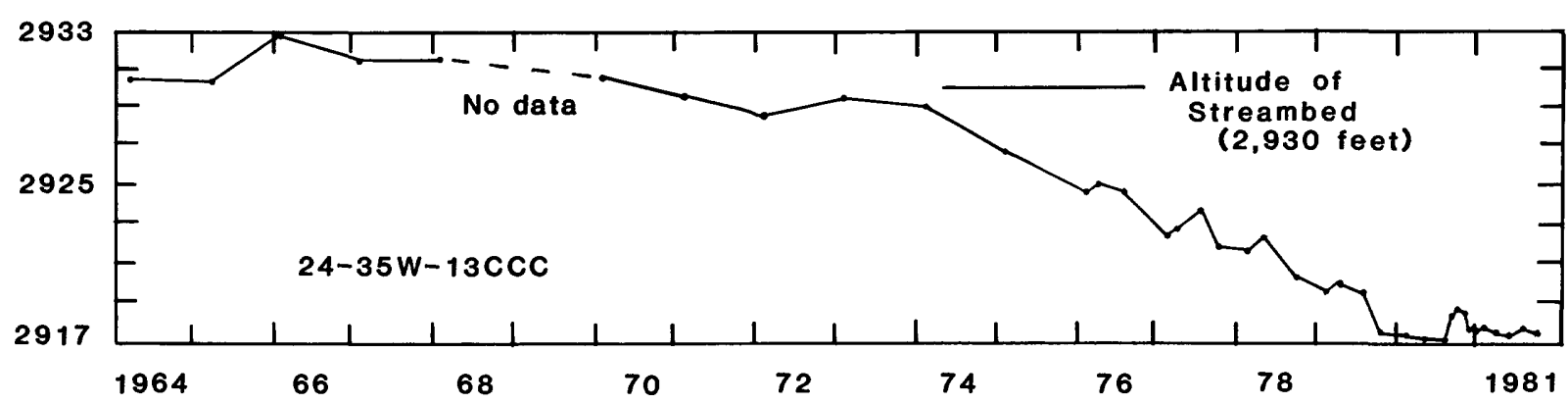

Figure 15. Hydrograph of a representative well in valley aquifer near Deerfield, $1964-81$. 


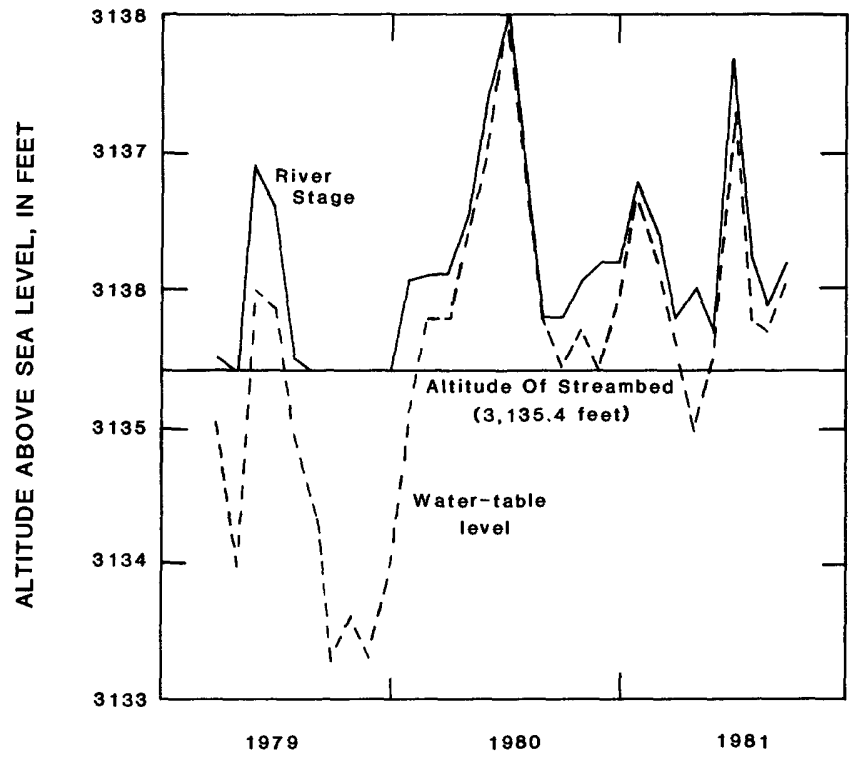

Figure 16. Comparison of Arkansas River stage to watertable level in valley aquifer near Kendall, 1979-81.

water table. As long as river stage remains high, the valley water table near the river continues to rise. Seepage from the river to the valley aquifer (and streamflow loss) decreases as the altitude difference between the river stage and the valley aquifer decreases, becoming insignificant when the water level in the valley aquifer nearly equals the river stage.

The stream-aquifer station at Kendall is an important indicator of hydrologic conditions because of its location just upstream from where irrigation canals in the phase-I study area begin diverting water. As shown in figure 16, during 1980-81 the river stage and water table at Kendall approximated one another when the altitude of the river stage was greater than 3,136.1 feet, corresponding to a stream discharge of greater than $75 \mathrm{ft}^{3} / \mathrm{s}$. Since seepage losses become insignificant when the altitude of the water table approximates river stage, reservoir releases from John Martin Reservoir, which result in a river flow greater than $75 \mathrm{ft}^{3} / \mathrm{s}$ at Kendall, will reduce the rate of seepage losses at Kendall. The stage-seepage loss relationship for Kendall is specific to that site, as well as the period of record examined and the antecedent flow conditions. Conditions at other sites and for other time periods undoubtedly would be different. Monitoring of the stream-aquifer station at Kendall would be of value for determining changes in the stage-seepage loss relationship.

At no time was the water-table level in the valley aquifer above the river stage at Kendall. In other words, ground-water discharge to the river did not occur at this site. But somewhere between Kendall and the Amazon Canal headgate, ground-water discharge occurred during the fall of 1980 and 1981, as indicated by an increase in streamflow between the two streamflow-gaging stations. When a high stage in the river occurred, a groundwater mound built up near the river in response to the seepage losses. Then, when the stage in the river receded, the ground-water mound discharged into the river resulting in the observed increase in streamflow. Ground-water discharge into the river ceased during the winter months when the mound dissipated below the altitude of the streambed.

The presence of a ground-water mound, however, was a localized and temporary occurrence. In general, as long as discharge (that is, ground-water pumpage) exceeds recharge (from streamflow and precipitation), water levels in wells will remain below the river-stage altitude, resulting in seepage losses from the river to the valley aquifer.

\section{Sinkholes}

Clear Lake is an unusual topographic feature in the valley aquifer near the western edge of the study area (fig. 4). Slichter (1906) reported Clear Lake to be a shallow depression 320-feet long, 280-feet wide, and 16-feet deep. Local residents during that time contemplated using the lake as a source of water for the Southside Canal.

Clear Lake and other shallow sinkholes occur along the ancestral Bear Creek, which overlies the Bear Creek fault zone in the study area. The original course of Bear Creek was choked by the encroachment of dune sand from the sandhills, leaving water from Bear Creek unable to flow northward into the Arkansas River (McLaughlin, 1943). Since the mid-1960's, the sinkholes have been dry except after heavy rains. A local resident reports that the depression at Clear Lake was 2-to-3-feet deep and 150 feet in diameter during the 1970's.

Early in 1979, Clear Lake began to collapse. By 1981, the sinkhole was 50-feet deep and 200 feet in diameter at the lake level. The lower 25 feet is filled with water. The diameter of the lake has been increasing an average of 1 foot per month. A staff gage in the lake shows that the stage is similar to water levels in nearby observation wells. Therefore, the surface of the lake represents the altitude of the water table. The collapsing of Clear Lake is probably due to subsurface dissolution and collapse of bedrock in the Bear Creek fault zone.

\section{Lower Aquifer}

A hydrograph for well 23-34W-21DDC, completed in the lower aquifer on the high plains, shows both seasonal fluctuations and an overall decline in hydraulic head (fig. 17). The large drawdowns observed in the summer are caused by irrigation pumpage from the lower aquifer. Larger than normal drawdowns in the summer are the result of heavier water use owing to hot, dry weather. The increased need for water must be met by ground-water pumpage because the amount of surface water available 


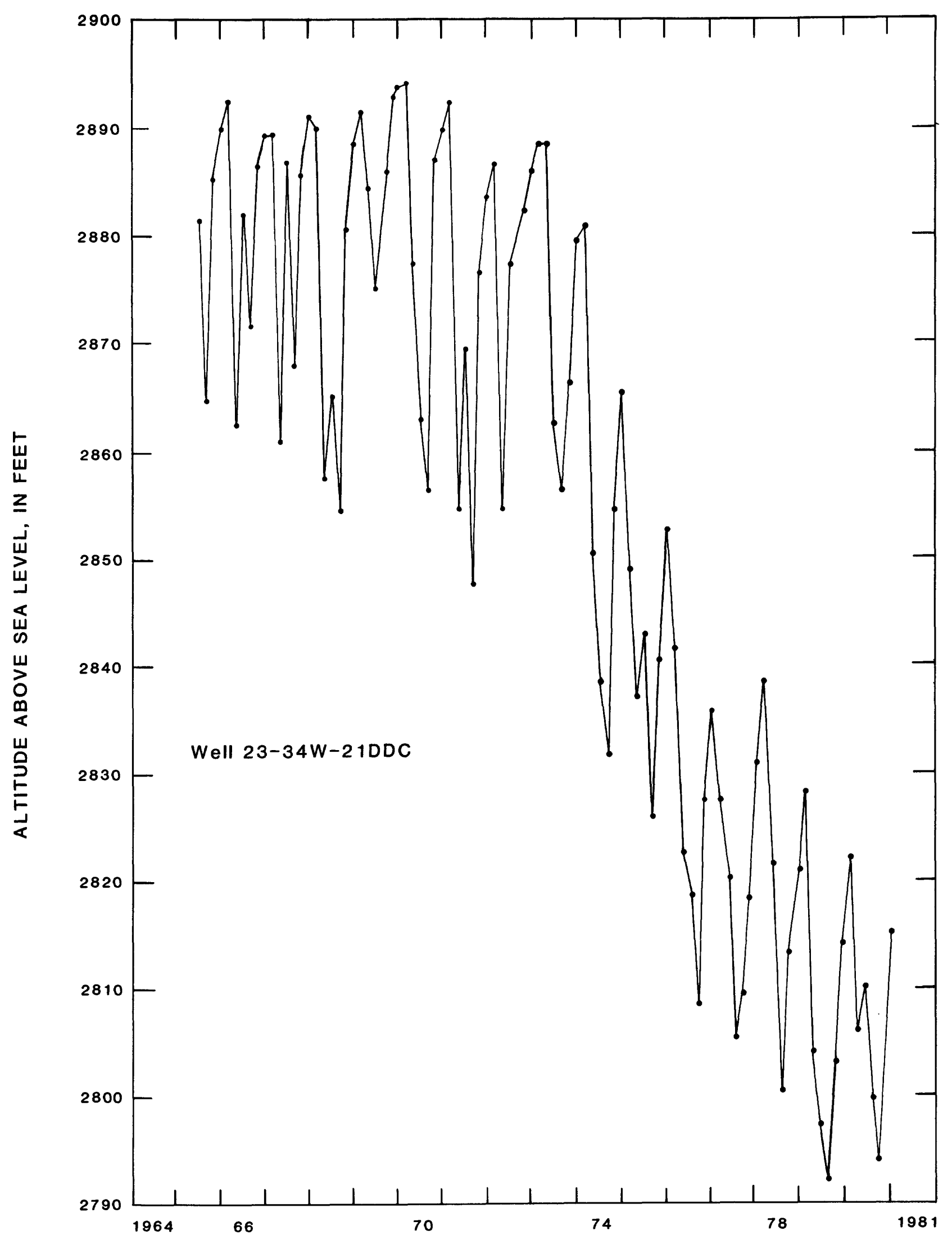

Figure 17. Hydrograph of a representative well in lower aquifer on high plains, 1965-80. 
from canals is inadequate for irrigation needs. The water level in the well recovers during the winter months (but not all the way back to the level for the previous winter) because of well shutdown.

Inspection of figure 17 shows that the annual waterlevel declines in a well tapping the lower aquifer on the high plains increased during the mid-1970's. For example, the 1966-74 average annual water-level decline was $1.29 \mathrm{ft} / \mathrm{yr}$, but the 1974-80 decline was $9.18 \mathrm{ft} / \mathrm{yr}$. Hydrographs for many wells on the high plains showed a similar increase in the rate of water-level declines during the mid1970 's, caused by both increased pumpage from the lower aquifer and the dewatering of the upper aquifer. Dewatering of the upper aquifer was caused by the downward leakage of water induced by increasing pumpage in the lower aquifer. As a result, the lower aquifer received less recharge, and hydraulic heads declined at a faster rate beginning in the mid-1970's.

\section{Interrelationship of Aquifers}

Historically, the hydraulic heads in the valley and upper aquifers were lower than the hydraulic heads in the lower aquifer. Water will move from an area of higher hydraulic head to an area of lower hydraulic head; therefore, water from the lower aquifer leaked upward through the confining zone into the valley or upper aquifers. Some of the water eventually discharged into the river. As ground-water irrigation development intensified, however, the potentiometric surface in the lower aquifer was depressed to a point where the hydraulic head in the lower aquifer was below the hydraulic head in the valley or upper aquifers during the irrigation season. Thus, water from the valley and upper aquifers leaked downward through the confining zone to the lower aquifer.

Prill (1977) described the interaction between the upper and lower aquifers at a site north of Holcomb during 1968. An examination of the hydrographs for two wells in the SW $1 / 4 \mathrm{SE}^{1 / 4} \mathrm{SW}^{1 / 4}$ sec. $26, \mathrm{~T} .23 \mathrm{~S}$., R.34 W. (fig. 18) indicates that the upper and lower aquifers were hydraulically connected.

The water levels in observation wells in both the upper and lower aquifers declined during the irrigation season and rose during the nonirrigation season. During the irrigation season, the hydraulic head in the lower aquifer was below the hydraulic head in the upper aquifer. The water table in the upper aquifer declined gradually during the irrigation season, while the potentiometric surface of the lower aquifer changed erratically in response to pumpage. Since little or no pumpage for irrigation from the upper aquifer occurred in the area, it is evident that water from the upper aquifer leaked downward to the

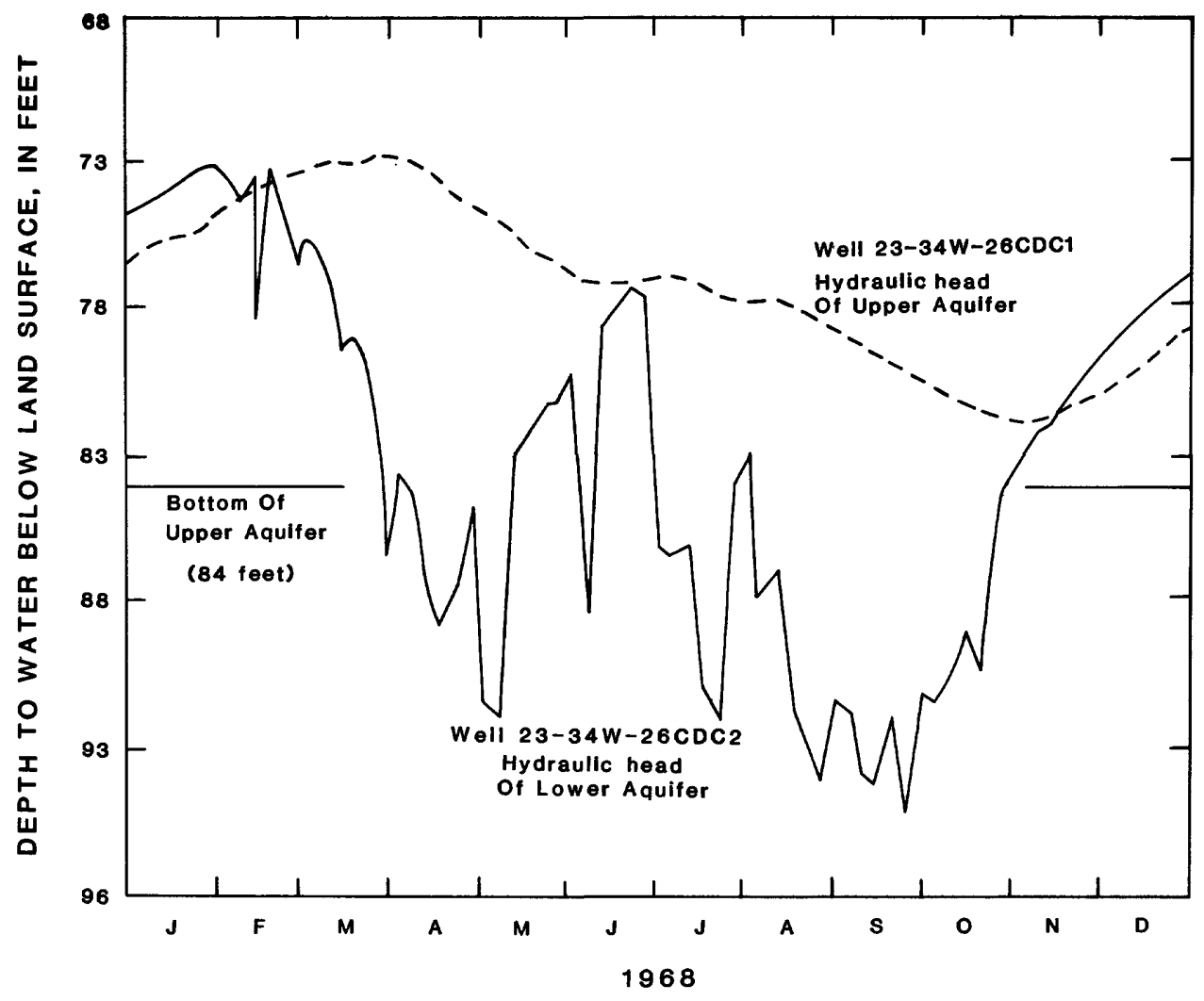

Figure 18. Water-level fluctuations in upper and lower aquifers during 1968 in observation wells 23-34W-26CDC1 and 23-34W-26CDC2 (from Prill, 1977). 
lower aquifer, resulting in the water-table decline observed in the upper aquifer.

During the nonirrigation season (winter months), the potentiometric surface of the lower aquifer rose to a level higher than the water table in the upper aquifer, and water moved upward into the upper aquifer, resulting in the water-table rise in the upper aquifer. In general, the lag time between potentiometric-pressure changes in the lower aquifer and water-table changes in the upper aquifer was about 3 weeks (Prill, 1977).

Well logs showed that the bottom of the upper aquifer is 84 feet below the land surface (Prill, 1977). Therefore, the saturated thickness in the upper aquifer varied between 2 and 11 feet during 1968.

As irrigation pumpage from the lower aquifer continued to increase, the potentiometric surface in the lower aquifer was depressed to such an extent that hydraulic heads in the lower aquifer remained lower than hydraulic heads in the valley and upper aquifers even during the winter nonirrigation season. Therefore, downward leakage of water from the valley and upper aquifers to the lower aquifer occurred throughout the year (as is the current hydrologic condition in the study area). The rate of leakage through the confining zone is dependent on the difference between the hydraulic head in the lower aquifer and the hydraulic head in the valley and upper aquifers, as well as the vertical hydraulic conductivity and thickness of the confining zone. Therefore, leakage from the valley and upper aquifers to the lower aquifer increased owing to both the lower potentiometric surface during the irrigation season (increasing the rate of leakage) and the longer duration of leakage (throughout the entire year rather than only during the irrigation season).

The result of the increased downward leakage of water from the valley and upper aquifers to the lower aquifer has been the water-table decline observed after 1973 in the valley aquifer near Deerfield (fig. 15); decreased recharge from the Arkansas River is also a contributing factor in the decline. Similar declines in the water table for the upper and valley aquifers have occurred in most of the study area. Widespread water-table declines have resulted in little or no ground-water discharge to the river.

Downward leakage of water from the upper aquifer to the lower aquifer has led to the dewatering of the upper aquifer on the high plains. The upper aquifer has not been dewatered in the sandhills south of the Arkansas River owing to its greater thickness there, and more importantly, because the sandhills have only recently experienced intensive irrigation development.

Hydrographs of the lower aquifer on the high plains indicate that the upper aquifer has been dewatered on the high plains since the mid-1970's. A long-term hydrograph of well $23-34 \mathrm{~W}-26 \mathrm{CCC}$ completed in the lower aquifer (fig. 19) shows the water level at an irrigation well 1,300 feet west of the Prill (1977) observation wells (fig. 18). The difference in land-surface altitude between the two locations is 2 or 3 feet. The January water level in the irrigation well declined an average of $0.97 \mathrm{ft} / \mathrm{yr}$ between 1966 and 1974, while from 1974 to 1980, the average decline was $9.6 \mathrm{ft} / \mathrm{yr}$.

Assuming geohydrologic conditions at irrigation well 23-24W-26CCC were similar to the Prill observation wells, the bottom of the upper aquifer at the irrigation well would have been 82 feet below the land surface. Since the water level in the irrigation well dropped below 82 feet during 1974 (and continued to decline thereafter), the upper aquifer would have been dewatered at that time.

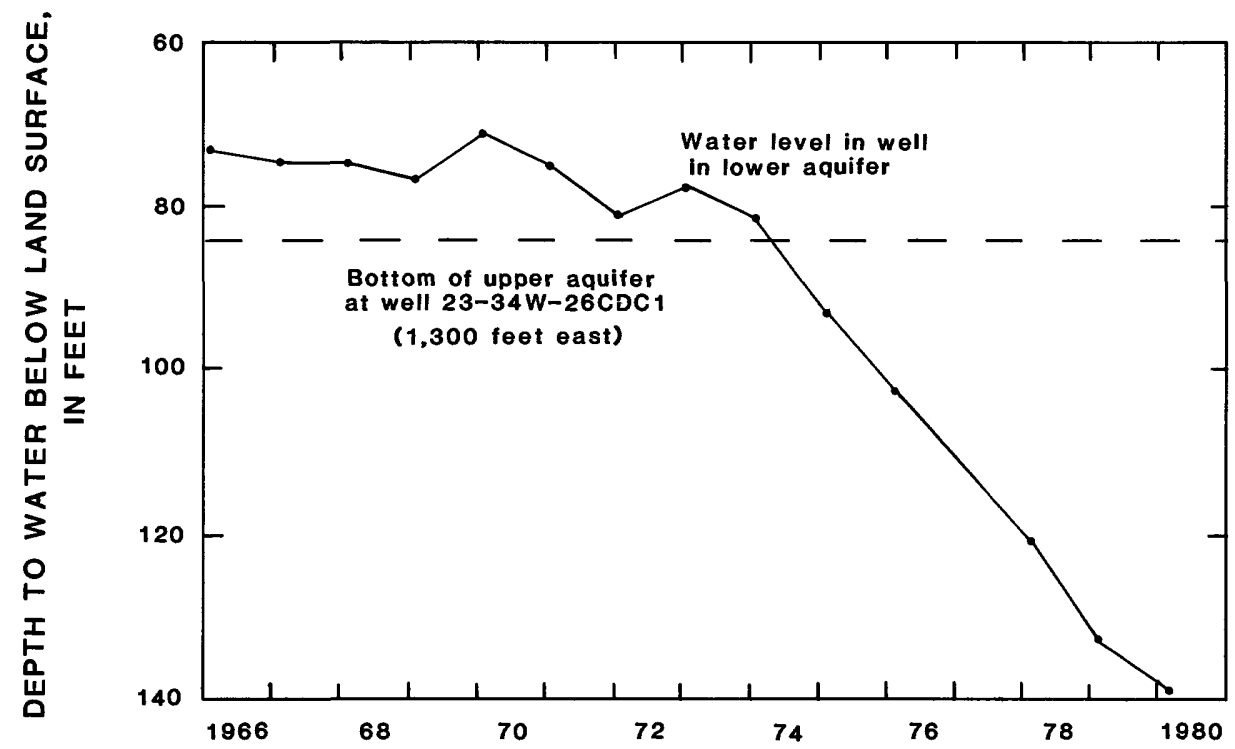

Figure 19. Hydrograph of irrigation well $23-34 \mathrm{~W}-26 \mathrm{CCC}$, representative of lower aquifer on high plains, $1966-80$. 
Comparison with the Prill observation wells indicates that January water levels for the upper and lower aquifers probably were similar before dewatering occurred. With the upper aquifer dewatered, the recharge to the lower aquifer would be decreased considerably, resulting in an increased rate of decline in the potentiometric surface of the lower aquifer. A similar increased rate of decline since the mid-1970's also can be noticed in figure 17.

The rapid rate of water-level decline will continue until the potentiometric surface of the lower aquifer falls below the bottom of the confining zone. When the potentiometric surface falls below the bottom of the confining zone (the confining zone is dewatered), the lower aquifer is no longer confined. The storage coefficient approaches the specific yield for unconfined conditions, and the rate of decline in the potentiometric surface of the lower aquifer then would decrease.

Increased irrigation pumpage from the lower aquifer was also a contributing factor to the increased rate of decline in the potentiometric surface of the lower aquifer on the high plains during the mid-1970's. However, the dewatering of the upper aquifer is considered the predominant factor. Although irrigation pumpage from the lower aquifer was increasing during the 1970's, there was no significantly larger pumpage increase in the mid1970's coinciding with the rather sudden increase in rate of water-level decline observed in many wells tapping the lower aquifer. Also, irrigation pumpage from the lower aquifer in the sandhills south of the Arkansas River was increasing at a faster rate during the 1970's than was occurring on the high plains. Yet no comparable increase in the rate of decline of water levels in wells tapping the lower aquifer in the sandhills has been observed. In contrast to conditions on the high plains, the upper aquifer has not been dewatered south of the Arkansas River.

Other factors accounting for the increased rate of decline in the potentiometric surface of the lower aquifer on the high plains may be that the mid-1970's was a time of low precipitation (fig. 13) and of decreased canal diversion from the Arkansas River (fig. 8). Both of these factors would necessitate increased irrigation pumpage from the lower aquifer in order to meet crop-consumptive needs, thus the increased potentiometric-surface decline. But dewatering of the upper aquifer is thought to be the major factor accounting for the increased rate of decline because (1) water levels in wells tapping the lower aquifer did not rise significantly during periods of higher precipitation (and, therefore, presumably lower irrigation pumpage), such as during 1977, and (2) observation wells as much as 5 miles away from irrigation canals declined at a similar rate as wells close to the irrigation canals, even during times when surface water was available for irrigation.

The response of the unconsolidated aquifer system near Lakin to flow in the Arkansas River is shown in figure 20. This hydrograph of three observation wells at 24-36W-34ACD and 24-36W-34ADC1,2 (2 wells) shows the changes in hydraulic head in the valley and lower aquifers and the confining zone. All three wells were less than 300 feet from the river. River stage is plotted so that its altitude can be compared with the altitude of the aquifer heads. Hydraulic heads in the lower aquifer were below the hydraulic heads in the valley aquifer and in the confining zone throughout the period of record shown.

During 1978-79, the hydraulic heads in the valley aquifer and the confining zone slowly declined due to downward leakage to the lower aquifer. The hydraulic head in the lower aquifer was depressed during the summer irrigation season but recovered during the winter months because of a cessation in irrigation pumping. The river was dry during 1978-79 except for a small flow during the summer of 1979 . This flow slightly recharged the unconsolidated aquifer system, as seen by the small rise in the water table in the valley aquifer during July 1979.

A period of flow resulting in a high river stage began during April 1980, and recharge from the river to the unconsolidated aquifer system occurred (fig. 20). The water-table altitude in the valley aquifer varied directly with the stage in the river, similar to the conditions near Kendall (fig. 16). However, the altitude difference between the river stage and the altitude of the streambed confining material near Lakin is greater than the altitude difference between the river stage and the water table in the valley aquifer near Kendall; therefore seepage losses are higher near Lakin. When the water table in the valley aquifer is below the altitude of the confining material in the streambed, seepage losses are maximized (for a given river stage). In other words, a lower water-table altitude will not induce a higher rate of seepage loss from the river if the water table in the valley aquifer is below the altitude of the streambed confining material. Because the thickness of unsaturated material near Lakin is greater than near Kendall, it will take a longer period of high river stage to recharge the valley aquifer. When the watertable altitude approximates the river stage, seepage losses become insignificant. Even the large amount of recharge from the river during 1980-81 near Lakin was insufficient to recharge the valley aquifer up to the river stage.

However, there is an additional impediment in recharging the valley aquifer east of the Bear Creek fault, which does not occur near Kendall. As the difference in hydraulic head between the valley and lower aquifers increases, the driving force for downward leakage from the valley aquifer to the lower aquifer also increases. Therefore, a rise in the water table in the valley aquifer due to recharge from the river will correspond to increased. downward leakage to the lower aquifer.

A ground-water mound does not build up above the 


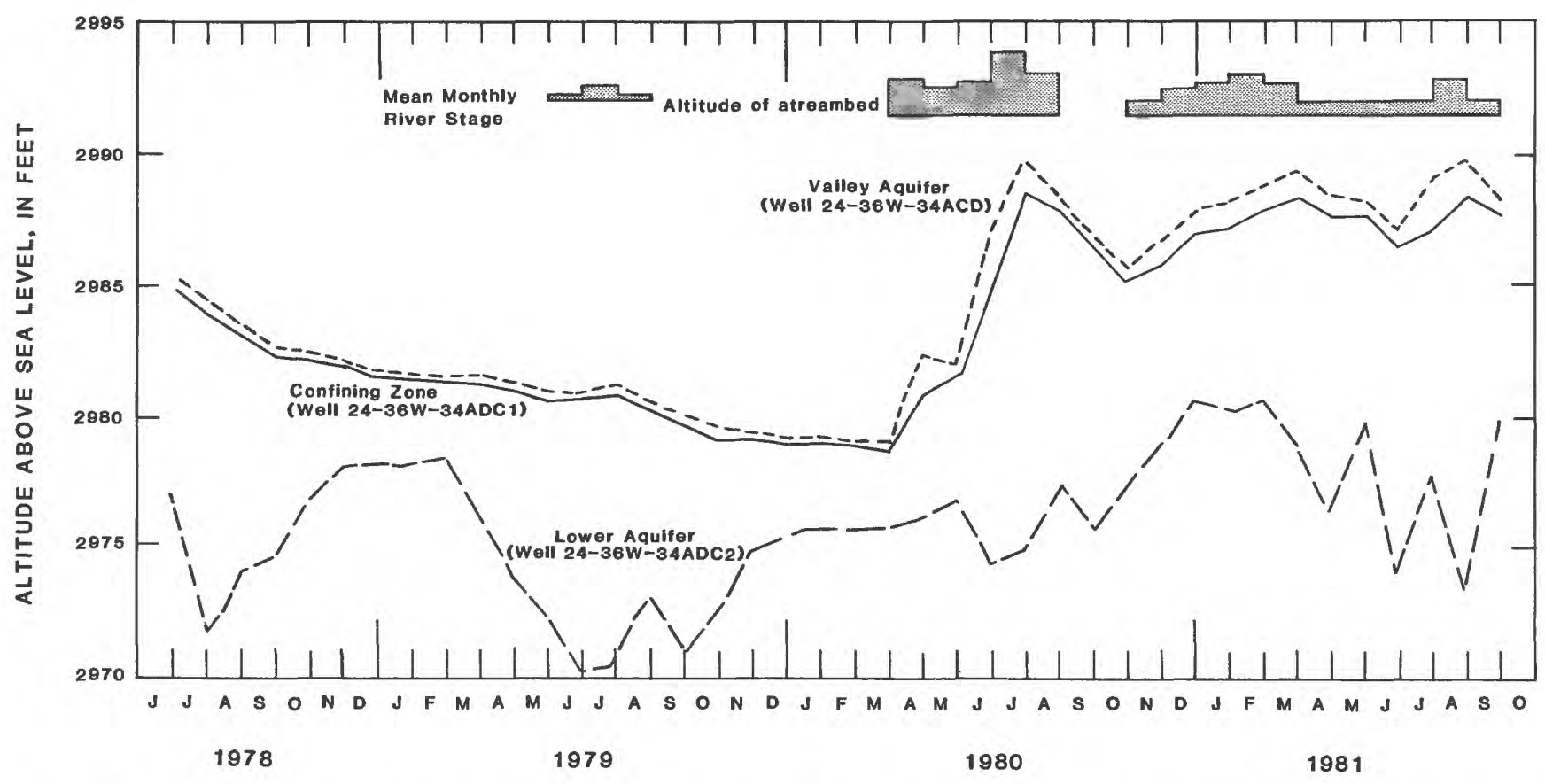

Figure 20. Relationship between Arkansas River stage and water levels in the unconsolidated aquifer system near Lakin, 1978-81.

altitude of the streambed near Lakin as it does between Kendall and the Amazon headgates. Therefore, there is no ground-water mound to discharge into the river when the stage recedes. The stream discharge observed at Lakin (fig. 6) during the winter and spring of 1980-81 was from ground-water discharge in the phase-I area.

The water level in the well tapping the lower aquifer near Lakin responded more slowly to discharge in the river than did water levels in wells tapping the valley aquifer or confining zone. Although the effects of pumping in the lower aquifer make it difficult to determine how the river affects the lower aquifer, the 5-foot rise in water level from January 1980 , to January 1981, in the well completed in the lower aquifer at Lakin indicates that recharge did occur. Most water levels in other observation wells tapping the lower aquifer in the study area declined during the same time period.

\section{COMPUTER MODEL ANALYSIS}

\section{Three-Dimensional Model}

The Trescott finite-difference model for simulation of three-dimensional flow (Trescott, 1975) was used in this study because of the need to simulate the interrelationship among the valley, upper, and lower aquifers. The iterative numerical technique used to solve the quasithree-dimensional flow equations is the strongly implicit procedure (SIP). The flow equation used for the unconsolidated aquifer system in the study area may be written as:

$$
\begin{gathered}
\frac{\partial}{\partial x}\left(T_{x x} \frac{\partial h}{\partial x}\right)+\frac{\partial}{\partial y}\left(T_{y y} \frac{\partial h}{\partial y}\right)+\frac{\partial}{\partial z}\left(b K_{z z} \frac{\partial h}{\partial z}\right)= \\
S^{\prime} \frac{\partial h}{\partial t}+b W(x, y, z, t)
\end{gathered}
$$

in which

$\mathrm{h}$ is the hydraulic head (L);

$T_{x x}$, Tyy are the principal components of the transmissivity tensor $\left(\mathrm{L}^{2} \mathrm{~T}^{-1}\right)$;

$S^{\prime}$ is the storage coefficient (dimensionless);

$\mathrm{K}_{\mathrm{zz}}$ is the vertical component of the hydraulic-conductivity tensor $\left(\mathrm{L} \mathrm{T} \mathrm{T}^{-1}\right)$;

$\mathrm{W}(\mathrm{x}, \mathrm{y}, \mathrm{z}, \mathrm{t})$ is the volumetric flux per unit volume $\left(\mathrm{T}^{-1}\right)$; and

$\beta$ is the thickness of the hydraulic unit.

\section{Finite-Difference Grid}

To solve the flow equation, the study area was divided into a grid of variable-sized, rectangular blocks, as shown in figure 21 . In each block, the aquifer properties are assumed to be uniform. The center of each block is called a node. The block dimensions are 1 mile by 3 miles near the river, and increase away from the river to provide the desired simulation with a minimum number of nodes. The grid consists of a three-dimensional system of nodes numbering 20 (north to south) by 16 (east to west) by 3 (top to bottom). A no-flow boundary with transmissivity equal to zero (rows 1 and 20 and columns 1 and 16 for the bottom layer) is inserted around the bor- 


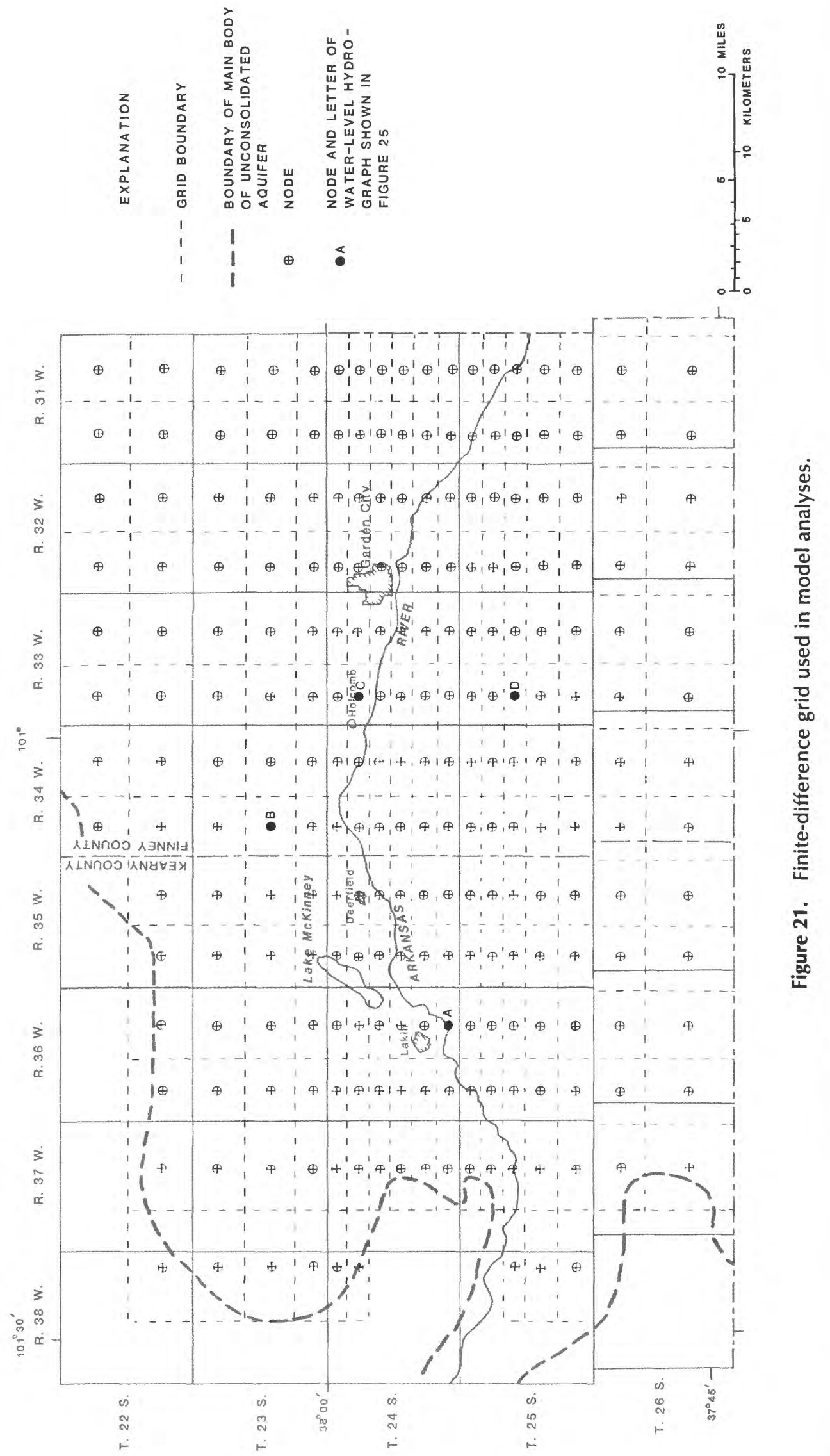


der of each layer in the Trescott finite-difference model for computational expediency.

Three vertical layers were used in the Trescott finite-difference model for this study. The top layer (layer 3 ) represented the valley and upper aquifers; the middle layer (layer 2), the confining zone; and the bottom layer (layer 1), the lower aquifer. Water storage did occur in the confining zone, but horizontal components of flow were considered insignificant. Aquifer-leakance values (TK) represented the vertical flow between the layers and were a function of vertical hydraulic conductivity and thickness of the confining zone. The vertical leakage was assumed to be steady.

\section{Aquifer Leakance}

To simulate the effects of vertical flow through the confining zone, aquifer-leakance values (equal to the vertical hydraulic conductivity divided by one-half the thickness of the confining zone) were used in the Trescott finite-difference model. Two leakance layers were simulated. The upper-aquifer leakance layer simulated the flow from the valley and upper aquifers to the confi ing zone. The lower-aquifer leakance layer simulated the flow from the confining zone to the lower aquifer.

\section{Model Boundaries}

In modeling studies of large aquifers, model boundaries should be extended to the physical boundaries of the aquifer to eliminate induced errors. However, due to the enormous amount of data that would be required, it was not feasible to extend the model boundaries to the natural boundaries of the unconsolidated aquifer system, except to the southwest. At the southwest boundary of the study area, the lower aquifer thins out to near zero saturated thickness. The distance from the Arkansas River valley to the northern boundary of the study area was ascertained by determining the radius of influence of a well field pumping at a discharge rate typical for the area and located in the river valley. The amount of drawdown experienced at the northern boundary due to the well field after 20 years of pumping was negligible. The southern and eastern boundaries of the study area coincide with political boundaries (county lines). There was negligible drawdown at these political boundaries from a well field pumping at a discharge rate typical for the area for 20 years and located in the Arkansas River valley near the center of the study area.

\section{Steady-State Model}

The Trescott finite-difference model was calibrated for both steady-state and transient conditions, termed the steady-state model and the transient model, respectively.
The steady-state model was formulated first to serve as a base for the transient model.

Prior to the 1950's, the unconsolidated aquifer system was in equilibrium or steady-state condition, meaning that fluxes into the system approximated fluxes out of the system and no significant changes in ground-water storage or hydraulic heads occurred over time. The steady-state model was calibrated to simulate conditions during 1940 because pumpage and water-level data were available for that year (Latta, 1944; McLaughlin, 1943).

\section{Boundary Conditions}

In order for the Trescott finite-difference model to derive a solution for the ground-water flow equation, either the hydraulic head or flux must be specified at the boundaries of the model. In the steady-state model, constant-head boundaries having a fixed value of static head depicted the effects of an equilibrium condition over time.

The Arkansas River is an important source of recharge to the unconsolidated aquifer system. Large seepage losses occur where the Arkansas River stage is above the water table. Before the 1970 's, the Arkansas River was both discharging and recharging the valley aquifer, depending on the location of the water table. River stage, streambed altitude, channel lengths and widths, and streambed leakance were specified in the steady-state model. The steady-state model held the river stage constant and calculated the amount of water gained or lost from the valley aquifer, based on the following equation:

$$
\mathrm{Q}=\frac{k^{\prime}}{b^{\prime}}\left(h_{s}-h_{a}\right) A
$$

where

$\mathrm{Q}=$ rate of leakage, in cubic feet per second;

$\underline{k^{\prime}}=$ Streambed leakance, or ratio of hydraulic con-

$\overline{b^{\prime}} \quad$ ductivity of the streambed, in feet per day, to thickness of the streambed, in feet;

$h_{s}=$ altitude of the stream stage, in feet;

$h_{a}=$ altitude of the water table, in feet; and

$A=$ wetted area of the streambed reach, in square feet.

A streambed-leakance value (equal to the ratio of hydraulic conductivity of the streambed to the thickness of the streambed) of 1.34 day $^{-1}$ was used for all riverbed nodes in the steady-state model; the same value that was used in the phase-I study (Barker and others, 1981).

Recharge from the irrigation canals and Lake McKinney was simulated with recharge wells. Recharge was set at $1.2 \mathrm{ft}^{3} / \mathrm{s}$ for every mile of the main canal in the grid block. Smaller branches that diverted water from the canal were given lower rates $\left[0.4\right.$ and $\left.0.8\left(\mathrm{ft}^{3} / \mathrm{s}\right) / \mathrm{mi}\right]$ 
of recharge. In addition, the calibrated rate of recharge from Lake McKinney was $9 \mathrm{ft}^{3} / \mathrm{s}$. These rates were adjusted in the steady-state calibration until the simulated water levels approximated the measured water levels.

\section{Precipitation}

Recharge to the unconsolidated aquifer system from precipitation in the Arkansas River valley and the sandhills was estimated to be 11 percent of the normal rainfall at Garden City, or $2.08 \mathrm{in} / \mathrm{yr}$. This percentage was obtained from the phase-I study (Barker and others, 1981) where similar soils were found. In that study, recharge was computed to be the excess of precipitation plus irrigation infiltration minus crop-consumptive use plus soilmoisture storage.

Recharge from precipitation on the high plains was considered to be negligible because the infiltration capacity of the soil is much lower, and less precipitation infiltrates to the unconsolidated aquifer system. Estimates of recharge are often less than $0.5 \mathrm{in} / \mathrm{yr}$ in soils typical of the high plains. Therefore, for the steady-state and transient models, it was assumed that recharge from precipitation on the high plains was insignificant when compared to other sources, such as pumpage and canal seepage.

\section{Hydraulic Conductivity}

Hydraulic conductivity is a measure of the aquifer's ability to transmit water. It was used in combination with saturated thickness to compute transmissivity. An initial estimate of $800 \mathrm{ft} / \mathrm{d}$ for the hydraulic conductivity of the valley aquifer was obtained from the phase-I study (Barker and others, 1981). The initial estimate was adjusted during the steady-state calibration. An areally constant hydraulic conductivity of $150 \mathrm{ft} / \mathrm{d}$ was used in the calibrated steady-state model for the valley aquifer. The upper aquifer is similar in lithology and was assigned the same hydraulic-conductivity value. The hydraulic conductivity of the confining zone was an areal constant of $0.0075 \mathrm{ft} / \mathrm{d}$, based on aquifer tests in the area.

The value of hydraulic conductivity for the lower aquifer was estimated from lithologic well logs using the vertical-variability method (Gutentag and Weeks, 1981). This method assigns a hydraulic-conductivity value to each lithologic layer in the $\log$ and then mathematically weights the layers to obtain a hydraulic-conductivity value for the well log. Values of hydraulic conductivity assigned to different lithologic layers conform with those given by Lappala (1978, table 6). The areally constant hydraulic conductivity used for the lower aquifer was an average value ( $93 \mathrm{ft} / \mathrm{d}$ ) calculated from one or two well logs per township in the study area.

\section{Specific Yield}

The magnitude of water-level change that occurs in an unconfined aquifer in response to recharge or discharge of ground water depends on the specific yield. The specif- ic yield of the alluvial aquifer in the phase-I study (Barker and others, 1981) ranged from 0.14 to 0.20 . Specific yield for the valley and upper aquifers in the phase-II study was adjusted during the steady-state calibration within that range $(0.14$ to 0.20$)$. A specific yield of 0.18 was used for the unconfined valley and upper aquifers in the calibrated steady-state model.

\section{Leakance}

Leakance (designated as $T K$ in the Trescott finitedifference model) was calculated by:

$$
T K=K^{1} / b^{1},
$$

where

$$
\begin{aligned}
T K & =\text { leakance }\left(\text { day }^{-1}\right) \\
K^{1} & =\text { vertical hydraulic conductivity, in feet per } \\
\text { day; and } & \\
b^{1} & =\text { thickness of the confining zone, in feet. }
\end{aligned}
$$

Values for each leakance layer were determined by dividing the estimated vertical hydraulic conductivity by onehalf the confining-zone thickness at each grid block. The vertical hydraulic conductivity was $0.0075 \mathrm{ft} / \mathrm{d}$, based on aquifer tests in the study area.

\section{Simulated Hydrologic Response}

The steady-state model is a numerical representation of the unconsolidated aquifer system under equilibrium conditions during 1940. During the steady-state calibration, recharge from irrigation canals and Lake McKinney, as well as the hydraulic conductivity and specific yield of the valley and upper aquifers, were adjusted within limits of expected values until the simulated water levels approximated the measured water levels. The contours of measured water levels in wells for 1940 and those simulated with the steady-state model are shown in figure 22 . During this time, vertical differences in hydraulic head in the valley, upper, and lower aquifers were minor; therefore, one water-level map is representative of the unconsolidated aquifer system.

\section{Transient Model}

With the increasing development of ground water for irrigation, equilibrium or steady-state conditions in the study area ceased to occur. The net withdrawal of water from the unconsolidated aquifer system began to exceed the natural recharge, resulting in water-level declines. The transient model was started in a time (1974) when nonsteady stresses were occurring; therefore, the dimension of time and changes in ground-water storage were incorporated. The transient model was set up to simulate the historical conditions from 1974 through 1980. Simulation of historical conditions from 1941 to 1973 was not attempted due to the tremendous amount of pumpage data that would have to be collected. 


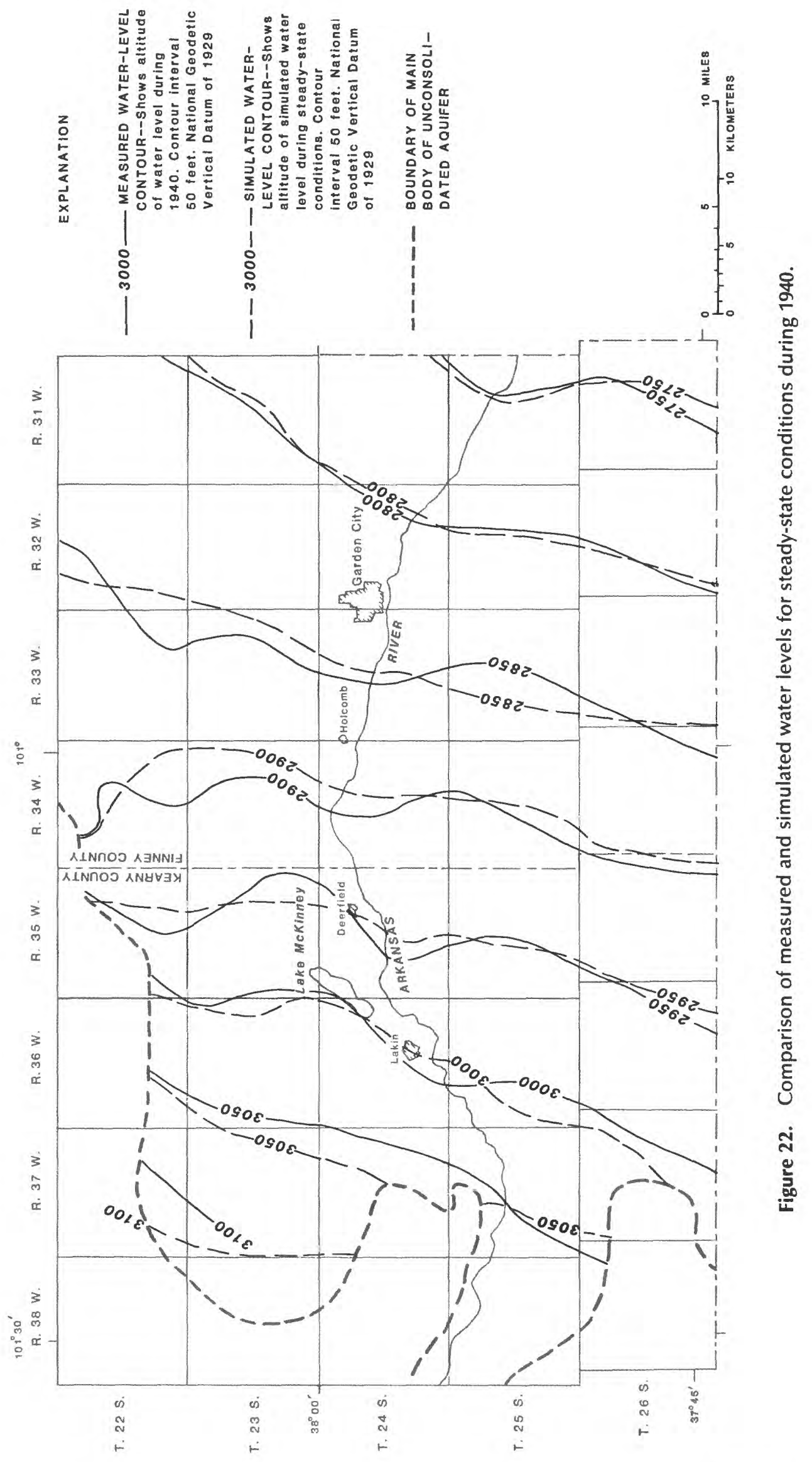


Using the transient model as a predictive tool in this study was based on the premise that if historic conditions can be approximated by the transient model, then so could future conditions. Therefore, it was important to simulate the historical stresses and the response to those stresses as accurately as possible. Also, it was assumed that the stresses observed in the past would not change significantly in the future.

\section{Time Steps and Pumping Periods}

The simulation of historical conditions required that time and pumping be divided into a series of finite intervals. To provide sufficient detail of pumping seasons, a progression of 4-month pumping periods was used for transient-model analyses.

\section{Boundary Conditions}

In the transient model, no-flow boundaries depicted the effects of an aquifer thinning out to near zero saturated thickness (fig. 23). The upper aquifer had been dewatered north of the Arkansas River by 1974, the first year of the transient-model calibration period (1974-80). The January 1974 potentiometric surface was below the bottom of the confining zone in the area outside the no-flow boundary for layer 2 (confining zone) north of the Arkansas River. The lower aquifer pinched out to near zero saturated thickness at the southwest boundary of the study area.

Constant-flux boundaries depicted the effects of a constant rate of water moving into or out of the aquifer for a specified period of time. The rate could change with a new pumping period. Constant-flux boundaries were used along the southern boundary for layer 1 (lower aquifer) where the lower aquifer is confined and no changes in saturated thickness occur. Constant-flux boundaries also were used to specify inflow to the valley and upper aquifers from the Arkansas River alluvium in the phase-I study area.

A constant-gradient boundary depicted a variable rate of ground-water flow moving into or out of the model boundary dependent on saturated-thickness changes. As the name implies, the constant-gradient boundary assumed that the hydraulic gradient across the model boundary remained relatively constant through time. This type of boundary served to update the flux across a grid block as the saturated thickness changed after each pumping period. The location of these boundaries also are shown in figure 23. For a further explanation of constant-gradient boundaries, see Dunlap (1980).

For the transient simulation, the Arkansas River was simulated with recharge wells because the river served only to recharge the unconsolidated aquifer system during 1974-80. Because of the declining water table in the valley aquifer, hydraulic connection between the river and the valley aquifer had been broken. Recharge was calculated by the difference between volumes of river water flowing past the streamflow gage just below the Amazon Canal headgate and at the Farmers Canal headgate (fig. 14). In other words, the difference in the volumes of water between the streamflow gages, accounting for the water diverted by Southside Ditch, was the estimated recharge. The recharge was distributed according to the length of the river in each grid block between the streamflow gages. A negligible amount of water flowed downstream of the Farmers Canal headgate from 1974 to 1980 (Howard Corrigan, Kansas State Board of Agriculture, oral commun., 1981); therefore, recharge to the valley aquifer downstream of the Farmers Canal headgate was negligible.

Recharge from the irrigation canals for the transient model was simulated with recharge wells in a manner similar to the steady-state model. However, the recharge was adjusted each pumping period in proportion to the actual number of months in the 4-month pumping period that the irrigation canals were transporting water.

\section{Hydraulic Conductivity}

The areally constant hydraulic-conductivity value used for the lower aquifer in the steady-state model ( 93 $\mathrm{ft} / \mathrm{d})$ was adjusted to a limited extent during the calibration of the transient model. An areally constant hydraulic conductivity of $115 \mathrm{ft} / \mathrm{d}$ was used in the calibrated transient model for the lower aquifer. Although variability is known to exist in this aquifer, a lack of data supported the use of one constant value.

Much of the lower aquifer is confined, so transmissivity values do not change with changes in hydraulic head. But in some areas of the lower aquifer, water-table conditions exist, and transmissivity values will change with changes in saturated thickness. Therefore, the Trescott finite-difference model code was modified to update transmissivity every time step when changes in saturated thickness occurred.

An areally constant hydraulic conductivity of 150 $\mathrm{ft} / \mathrm{d}$ was used in the transient model for the valley aquifer. The upper aquifer is similar in lithology and was assigned the same hydraulic-conductivity value.

The hydraulic conductivity of the confining zone was an areal constant of $0.0075 \mathrm{ft} / \mathrm{d}$ based on aquifer tests in the area.

\section{Storage Coefficient and Specific Yield}

Storage coefficient is the volume of water an aquifer releases from or takes into storage per unit surface area of the aquifer per unit change in head. The storage coefficient for the confining zone was 0.001 . An initial areaconstant estimate of storage coefficient for the confined part of the lower aquifer was varied universally during 

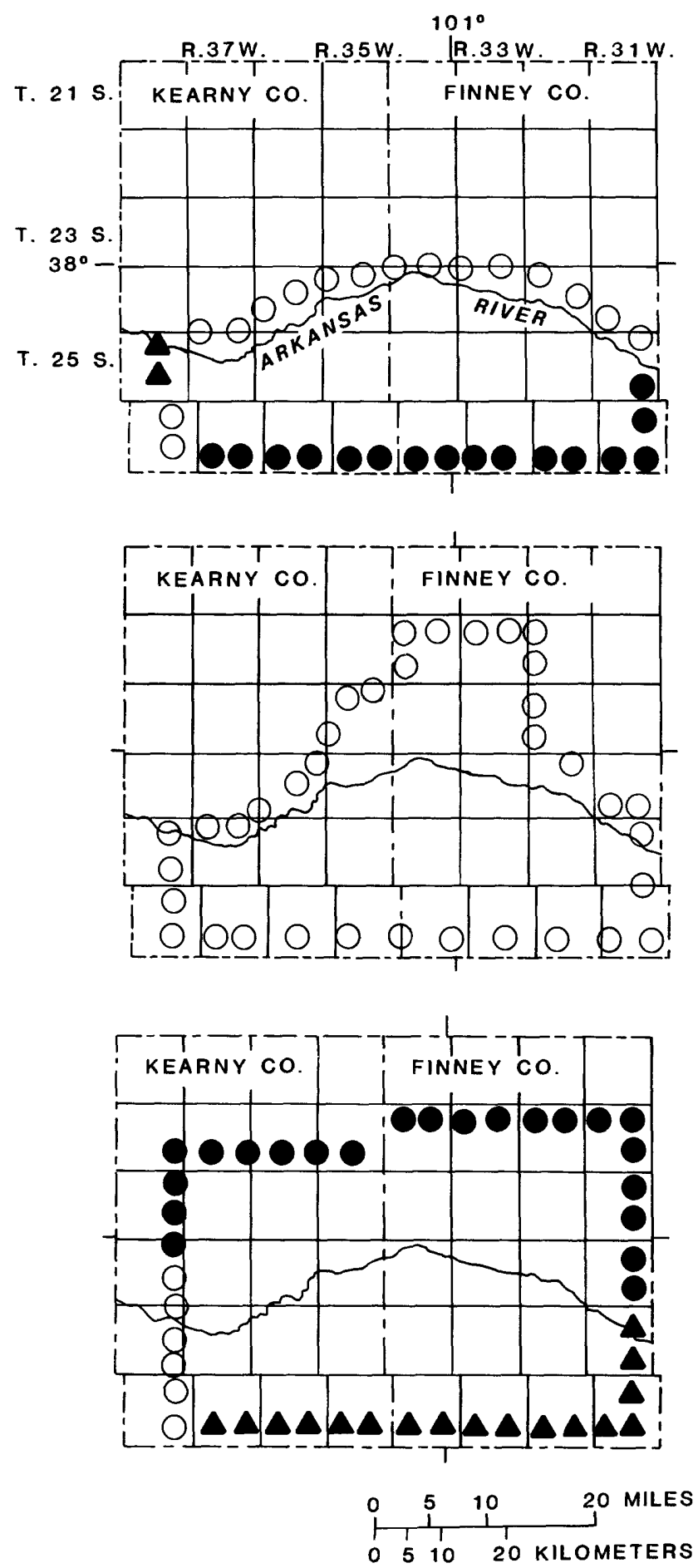

LAYER 3

Valley and upper aquifers

LAYER 2

Confining zone

\section{LAYER 1}

Lower aquifer

\author{
EXPLANATION
}

NO-FLOW BOUNDARY

CONSTANT-FLUX

BOUNDARY

CONSTANT-GRADIENT

BOUNDARY

Figure 23. Boundary conditions used in transient model.

transient calibration to improve agreement between measured and simulated water-level fluctuations. The final calibrated value for the storage coefficient in confined areas was 0.01 . Modifications were made in the Trescott finite-difference model code to change the storage coefficient for the lower aquifer from 0.01 to 0.18 when confined areas in the lower aquifer went to water-table conditions.
A specific yield of 0.18 was used for the unconfined valley and upper aquifers.

\section{Leakance}

The initial estimates of leakance (from the calibrated steady-state model) were varied universally by a common factor during the transient calibration to improve agreement between measured and simulated water levels in the 
valley and lower aquifers. Calibrated leakance values ranged from $1 \times 10^{-5}$ to $1 \times 10^{-9}$ day $^{-1}$.

For some areas in the unconsolidated aquifer system, dewatering of the valley aquifer and confining zone occurred during the simulation period. When this happened, aquifer-leakance and transmissivity values were set to zero in the affected nodes, and recharge (precipitation and irrigation-canal seepage, if any) was added to the pumpage in the lower aquifer (implemented by modifications in the Trescott finite-difference model code). It was assumed that recharge was less than aquifer leakance, and therefore the valley aquifer and confining zone were not resaturated at a later time once the dewatering had occurred.

\section{Pumpage}

Crop-water demand and the amount of irrigated acreage were used to estimate pumpage in the phase-II study area. A soil-zone model used by Lappala (1978, p. 94) in Nebraska estimates the amount of irrigation water, in addition to precipitation, needed to grow an irrigated crop. The soil-zone model tabulated soil moisture and crop-water demand for various crops and totaled the irrigation-water application needed to maintain the available soil moisture at a specified percentage. Data needed for the soil-zone model include precipitation, temperature, potential evapotranspiration, and soil characteristics.

Crop-irrigation demand (amount of irrigation water needed) was calculated for corn, grain sorghum, alfalfa, and wheat. Irrigated acreage on farms for these crops were obtained from the files of the U.S. Agriculture Stabilization and Conservation Service in Garden City and Lakin (1974-80). The pumpage from 1974 through 1980 was calculated over 4-month periods because of the seasonal changes in crop acreage and crop-irrigation demand. Pumpage was calculated for each township and proportioned to each grid block in the transient model by the ratio of the number of wells in the grid block to the total number of wells within the township. All pumpage was assumed to come from the lower aquifer, except when the crop-irrigation demand could be met by surface water from irrigation canals. The amount of surface water available for irrigation was subtracted from the pumpage in the appropriate grid blocks.

Precipitation during some months exceeds cropwaterdemand. Therefore, the soil-zone model also calculates the amount of water that goes to surface-water runoff and to ground-water recharge (deep percolation) on irrigated land. When this recharge occurs, it is considered to reach the lower aquifer instantaneously. However, in this study irrigation (return-flow) recharge was insignificant in comparison to other recharge and pumpage. Therefore, it was not deducted from irrigation pumpage or added to surface recharge.

The potential well yield has decreased in the study area as a result of decreasing saturated thickness. During calibration of the transient model, adjustments were made to pumpage when saturated thickness of the lower aquifer was less than 50 feet. When saturated thickness was less than 50 feet, it was assumed that well yield had decreased to a point where the original pumpage could not be maintained by pumping for a longer period of time. Therefore, the new well discharge was computed to be:

$$
Q_{\text {new }}=Q_{\text {input }}\left(\frac{m \text { present }}{m \text { original }}\right)^{2},
$$

where

$$
\begin{gathered}
Q_{\text {new }}=\begin{array}{c}
\text { well discharge after adjustment, in cubic } \\
\text { feet per second; }
\end{array} \\
Q_{\text {input }}=\begin{array}{c}
\text { well discharge calculated from soil-zone } \\
\text { model, in cubic feet per second; and }
\end{array} \\
m=\begin{array}{c}
\text { saturated thickness at different times, in } \\
\text { feet. }
\end{array}
\end{gathered}
$$

This equation was approximated from the Dupuit assumptions in unconfined flow (D. G. Jorgensen, U.S. Geological Survey, written commun., 1978).

Viability of this method of reducing well discharge with decreasing saturated thickness is shown by a comparison of results with a study in Kearny County by Gutentag and others (1972). In that study, a relationship was developed between the decline in potential well yield and the decrease in saturated thickness of the lower aquifer. The relation of potential yield from well-discharge tests in Kearny County to saturated thickness is compared with the decrease in well yield calculated from equation 4 (fig. 24). The similarity of the lines indicates that equation 4 can be used as a valid estimation of declines in well yield when saturated thickness is known.

Dunlap (1980) compared the crop-water demand and irrigated acreage method of determining pumpage with actual measurements in west-central Kansas. The pumpage estimated from crop-water demand and irrigated acreage was within 5 percent of pumpage determined from totalizing flow meters and hour meters installed in the irrigation systems of west-central Kansas.

\section{Simulated Hydrologic Response}

Before the transient model could be used to assess future hydrologic conditions or used to consider any hypothetical changes in the stream-aquifer system, it was necessary to demonstrate that the model could simulate measured responses to historic conditions. Therefore, the transient model's reliability was tested during the calibration phase by comparing simulated hydraulic heads in the valley and lower aquifers to those actually measured in the study area. A significant amount of time was spent in calibrating the transient model to reproduce the measured water-level changes in wells in response to 


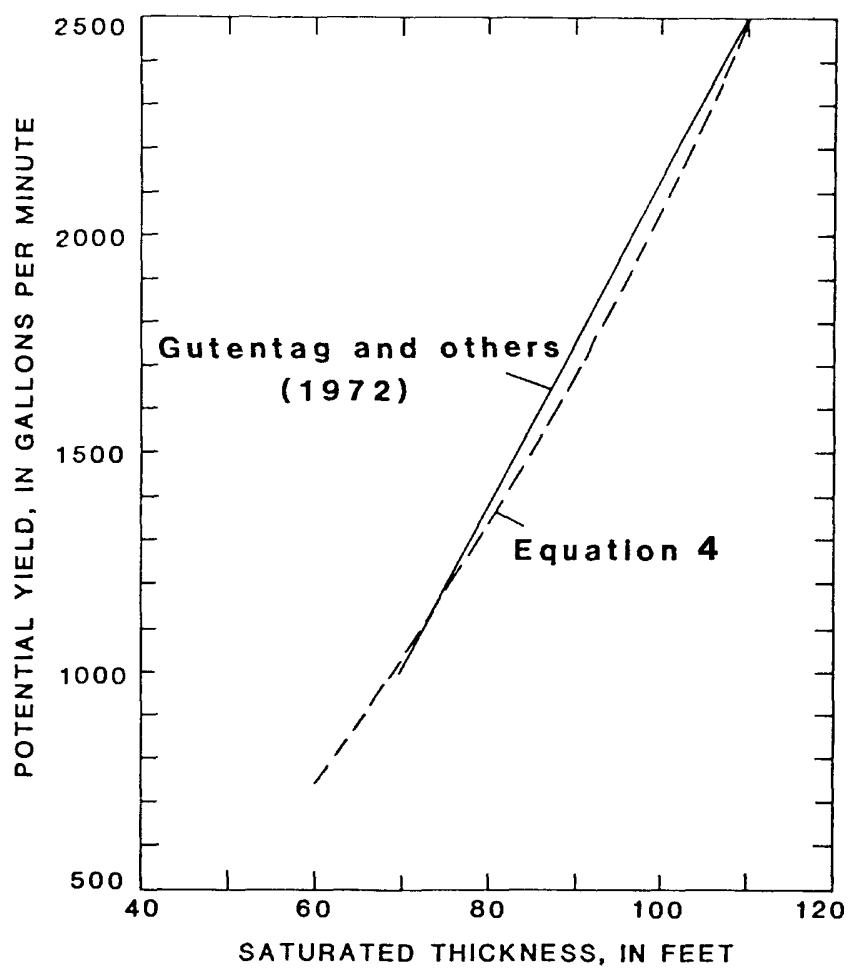

Figure 24. Comparison of potential well yield and saturated thickness from Gutentag and others (1972) to wellyield decrease from equation 4 . Reprinted from Dunlap and others (1980).

streamflow, precipitation, and pumpage. During the calibration, aquifer leakance and storage coefficient of the lower aquifer (also hydraulic conductivity of the lower aquifer to a limited extent) were adjusted within limits of expected values to provide a satisfactory approximation of the historic water-level changes. This section of the report provides comparisons of measured and simulated water levels and the water budget calculated by the transient model.

The transient model represents the unconsolidated aquifer system from 1974 through 1980. During this time, the net withdrawal of water from the unconsolidated aquifer system exceeded the natural recharge, resulting in declines in hydraulic heads. The measured water levels are compared with simulated water levels in selected observation wells in figure 25 . Each simulated hydrograph represents fluctuations in the hydraulic head at the center of the grid block (node) closest to the observation well. So that hydraulic-head changes could be compared equally, the starting hydraulic-head altitude (January 1974) of the measured hydrograph was changed so that the measured and simulated hydrographs would have the same starting reference point. Changes in measured and simulated water levels in wells then were added to (rises) or subtracted from (declines) this common starting reference point.

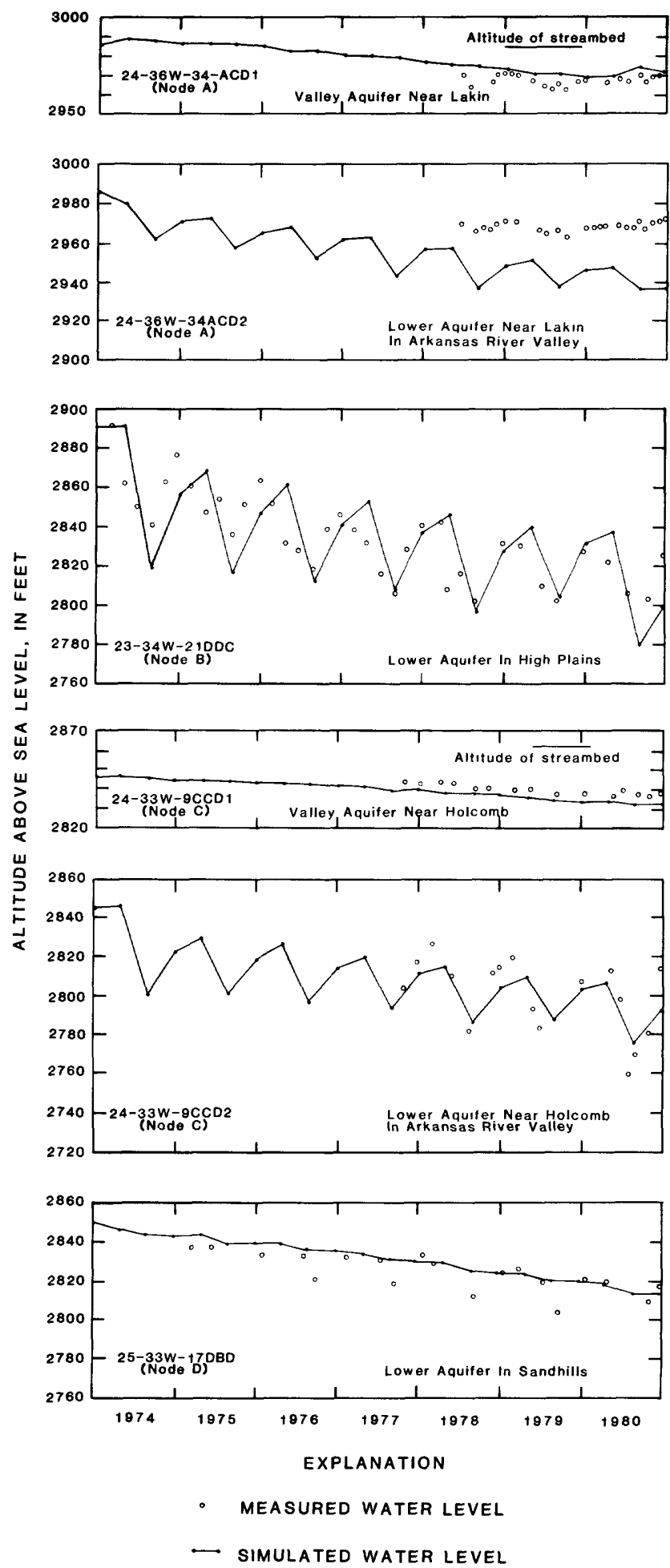

Locations of nodes are shown in figure 21

Figure 25. Measured and simulated water levels in selected observation wells, 1974-80.

Measured and simulated water levels in wells were compared for both the valley and lower aquifers for each physiographic area in figure 25 . The altitude of the 
streambed closest to the grid node (center of grid block) was plotted on the valley hydrographs. A hydraulic head (in the valley aquifer) below this streambed altitude indicates no discharge to the river from the valley aquifer at this site.

Data collection for the measured water levels in wells near Holcomb (24-33W-9CCD 1 and 2) began during 1977 and near Lakin (24-36W-34ACD 1 and 2) during 1978. Near Lakin, the measured water level in the well tapping the lower aquifer is consistently higher than the simulated water level. The Arkansas River is a source of recharge to the unconsolidated aquifer system at this site. Therefore, the area nearest the river would have a higher hydraulic head than the average hydraulic head for an area the size of a grid block.

The water-table contours simulated by the transient model for the valley and upper aquifers reasonably matched the January 1981 , measured water-table contours in the valley aquifer (fig. 26). The measured water-table contours in the upper aquifer are not drawn due to the scarcity of data. The potentiometric surface of the lower aquifer simulated by the transient model also reasonably matched the January 1981, measured potentiometric surface (fig. 27).

A closer match between the measured and simulated hydraulic heads could have been obtained if aquiferleakance and storage-coefficient (the principal values varied during the transient calibration) values were individually altered in the vicinity of the measured wells. Although it is recognized that some heterogeneity exists in the aquifer, few data are available to document the areal differences. Therefore, any further attempt to improve the match between measured and simulated hydraulic heads by altering the aquifer characteristics from the areally constant values was deemed impractical and unjustified.

\section{Water Budget}

Along with simulating hydraulic-head changes, the calibrated transient model provided a simulated water budget for the unconsolidated aquifer system. A tabulation of this budget is presented in table 1 for 1974-80.

The simulated water budget shows that from the amount of water that was discharged from the aquifer system due to pumpage and boundary outflow; (1) 10 percent came from precipitation, (2) 6 percent came from river and canal seepage and boundary inflow, and (3) 84 percent came from loss of ground water from storage, causing water levels in wells to decline.

A more detailed, simulated water budget for 1980 is given in table 2 and illustrated in figure 28. The Arkansas River streamflow during 1980 was the largest for 1974-80. The water budget shows that 429,900 acre-feet of water leaked downward from the valley and upper aquifers to the confining zone. Similarly, 432,200 acrefeet of water leaked downward from the confining zone to the lower aquifer. Nearly 42 percent of the water pumped from the lower aquifer came from loss of water from storage in the lower aquifer. Since the boundary inflow and outflow are nearly equal (a difference of 11,400 acre-ft/yr), almost 58 percent of the water pumped from the lower aquifer came from vertical leakage from the confining zone. Additionally, the confining zone lost 2,300 acre-feet of water from storage to leakage to the lower aquifer during 1980. Therefore, 99 percent of the water that leaked down from the confining zone to the lower aquifer originated from leakage from the valley and upper aquifers. Most ( 80 percent) of the water that leaked down from the valley and upper aquifers came from storage losses in those aquifers.

\section{Sensitivity Tests}

When calibrating a model, there is always some degree of uncertainty about the accuracy of some of the hydrologic values used in the model. Sensitivity of the model to changes in selected values was examined by individually changing aquifer characteristics within their expected ranges and by observing the resulting changes in hydraulic head. The characteristics selected to test for sensitivity were (1) hydraulic conductivity of the valley and upper aquifers, (2) natural recharge, (3) storage coefficient of the lower aquifer, and (4) aquifer leakance. These characteristics were selected because the calibrated values in the transient model were thought to involve greater uncertainty with regard to their actual value than the others used in the model. Hydraulic conductivity of the lower aquifer, specific yield of the valley and upper aquifers, streamflow and canal seepage, and pumpage were thought to involve less uncertainty than the characteristics tested.

Changes in hydraulic head in the valley aquifer resulting from changes in selected hydrologic values are illustrated by water-level hydrographs (fig. 29). The hydrographs give the simulated hydraulic heads in the valley aquifer from January 1, 1974, to December 31, 1980, at a grid block (row 8, column 10, fig. 21) near the center of the study area using calibrated and changed hydrologic values. Inspection of hydrographs of hydraulic heads for the valley aquifer for other grid blocks in the transient model indicated similar changes in hydraulic head in response to changes in hydrologic values.

Changes in hydraulic head in the lower aquifer resulting from changes in selected hydrologic values are illustrated by hydrographs along a north-to-south cross section (fig. 30) near the center of the transient-model grid. The hydrographs give the December 31, 1980, simulated hydraulic heads in the lower aquifer at each node in column 10 of the transient-model grid (fig. 21) for the calibrated and changed hydrologic values. A cross section was used for the lower aquifer in order to show the effects of the north-to-south variability that exists in the lower aquifer. Inspection of other north-to-south cross sections 


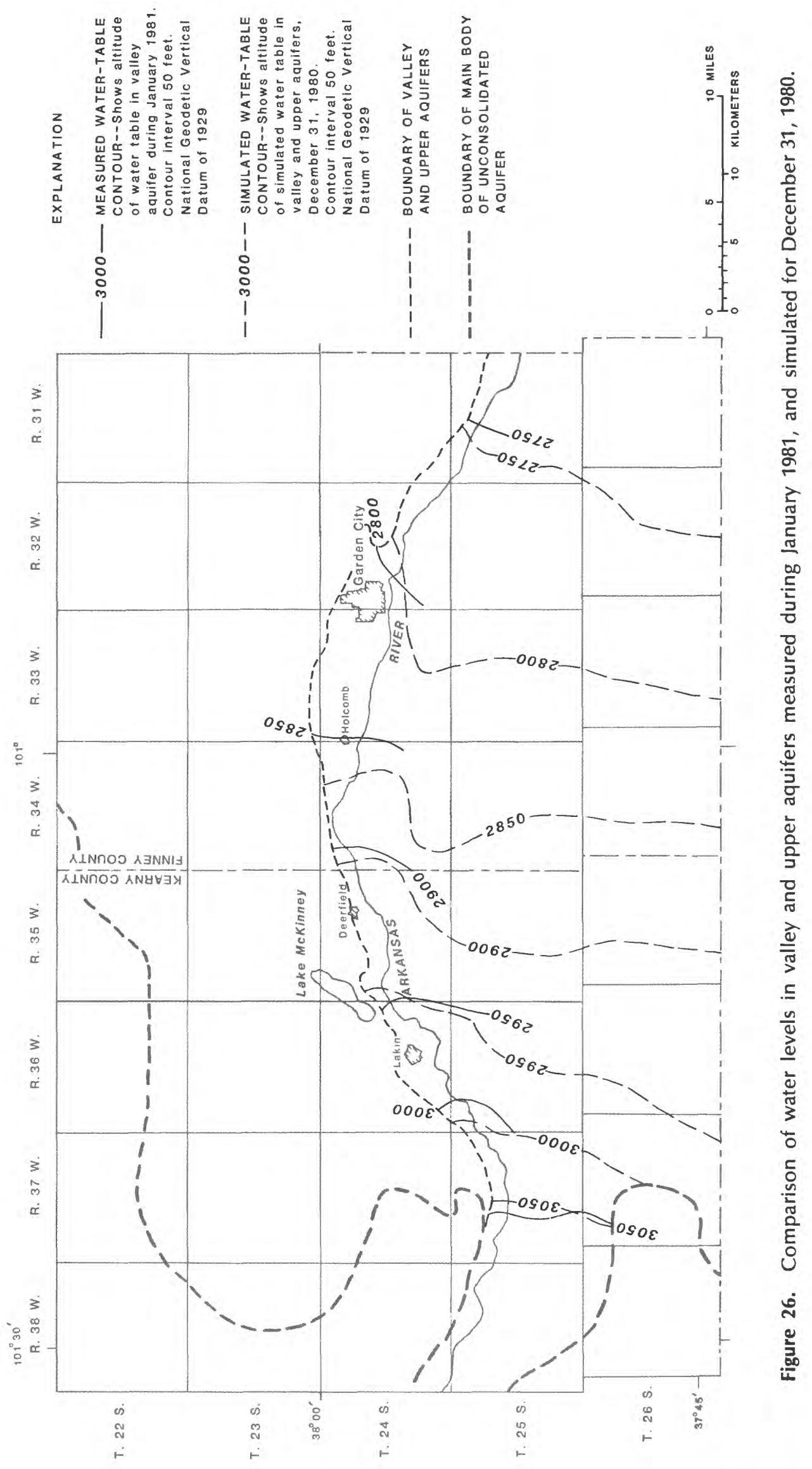




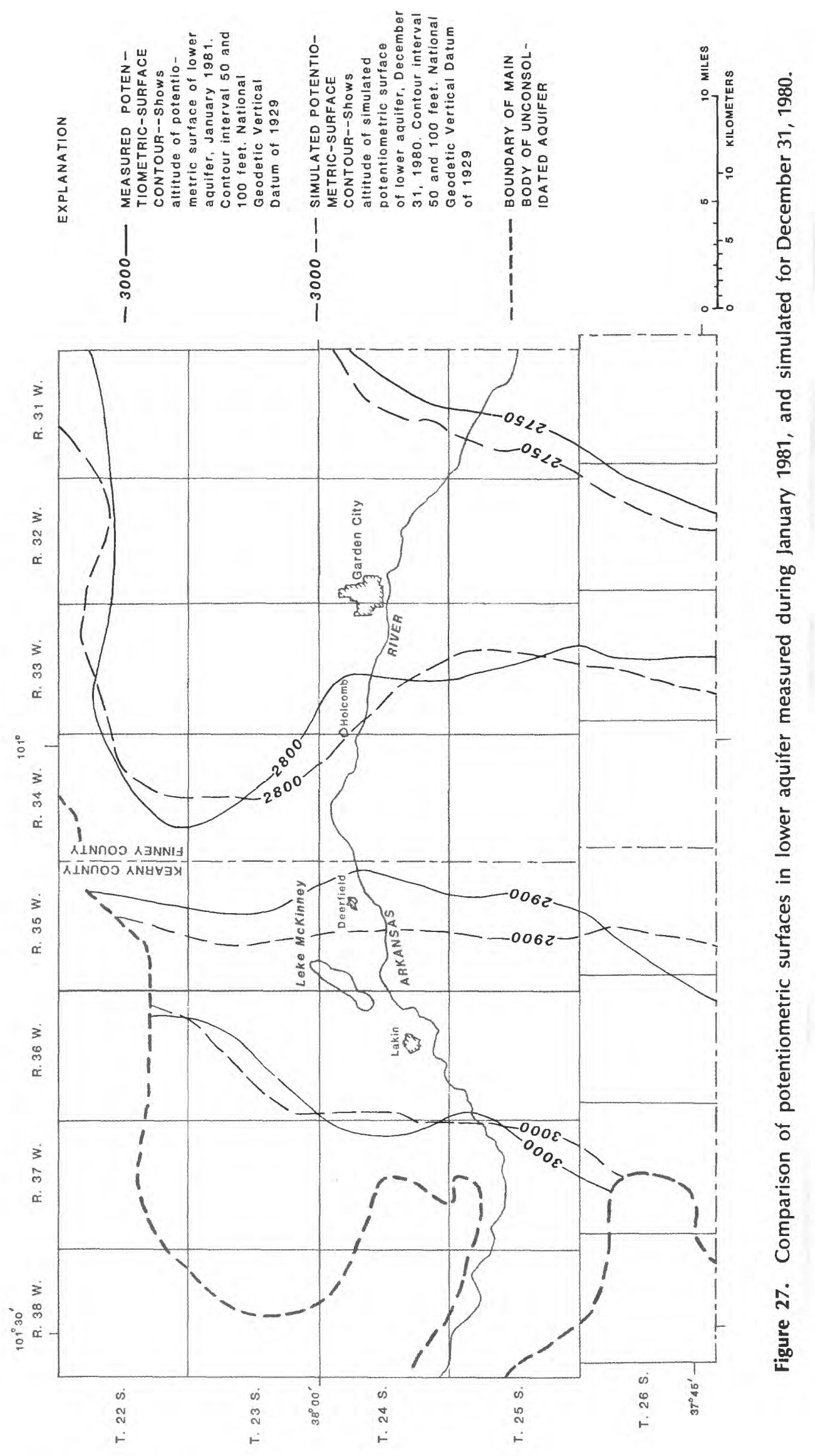


Table 1. Simulated water budget for unconsolidated aquifer system, 1974-80

[Average annual values in acre-feet per year]

\begin{tabular}{|c|c|c|}
\hline & Recharge & Discharge \\
\hline Precipitation ....................... & 66,900 & --- \\
\hline River and canal seepage and boundary inflow $\ldots \ldots \ldots \ldots \ldots \ldots$ & 36,200 & --- \\
\hline Loss of ground water from storage & 531,700 & --. \\
\hline 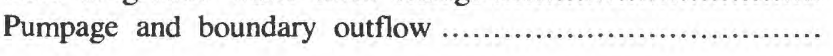 & $\ldots$ & $\underline{634,800}$ \\
\hline Total & 634,800 & 634,800 \\
\hline
\end{tabular}

Table 2. Simulated water budget for unconsolidated aquifer system, 1980 [Values are given in acre-feet per year]

\begin{tabular}{|c|c|c|}
\hline & Recharge & Discharge \\
\hline \multicolumn{3}{|l|}{ Valley and upper aquifer } \\
\hline Precipitation ............. & 66,900 & --- \\
\hline River and canal seepage & 35,300 & -- \\
\hline Boundary inflow & 12,000 & -.. \\
\hline Boundary outflow. & --- & 28,900 \\
\hline Loss of ground water from storage $\ldots \ldots \ldots \ldots \ldots \ldots \ldots \ldots$ & 344,600 & $\cdots$ \\
\hline Leakage to confining zone & $\ldots$ & 429,900 \\
\hline \multicolumn{3}{|l|}{ Confining zone } \\
\hline Leakage from valley and upper aquifer $\ldots \ldots \ldots \ldots \ldots \ldots \ldots \ldots \ldots \ldots \ldots$ & 429,900 & --- \\
\hline Loss of ground water from storage & 2,300 & --- \\
\hline Leakage to lower aquifer..................... & --.- & 432,200 \\
\hline \multicolumn{3}{|l|}{ Lower aquifer } \\
\hline Leakage from confining zone & 432,200 & -.- \\
\hline Canal seepage & 12,400 & -.. \\
\hline 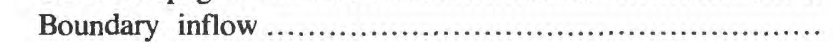 & 17,300 & --- \\
\hline 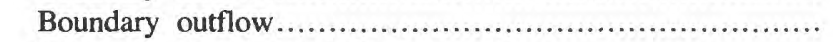 & -.- & 28,700 \\
\hline Loss of ground water from storage & 307,600 & --- \\
\hline Pumpage &.-- & 740,800 \\
\hline Total & $1,660,500$ & $1,660,500$ \\
\hline
\end{tabular}

in the transient-model grid indicated similar changes in hydraulic heads in response to changes in hydrologic values.

\section{Response of Valley Aquifer}

A hydraulic conductivity of $150 \mathrm{ft} / \mathrm{d}$ was used in the calibrated transient model for the valley and upper aquifers. A 50-percent increase in hydraulic conductivity $(225 \mathrm{ft} / \mathrm{d})$ resulted in slightly higher hydraulic heads in the valley aquifer. A 50-percent decrease in hydraulic conductivity $(75 \mathrm{ft} / \mathrm{d})$ resulted in slightly lower hydraulic heads in the valley aquifer. The deviations in hydraulic head (for a 50-percent increase or decrease in hydraulic conductivity) from the calibrated hydraulic head on December 31 , 1980, were less than 1 foot.
A value of $2.08 \mathrm{in} / \mathrm{yr}$ was used for natural recharge in the calibrated transient model. A 50-percent increase in natural recharge (3.12 in/yr) resulted in higher hydraulic heads in the valley aquifer, nearly 3 feet higher than the calibrated head on December 31, 1980. A 50-percent decrease in natural recharge (1.04 in/yr) resulted in lower hydraulic heads in the valley aquifer, nearly 3 feet lower than the calibrated head on December 31, 1980.

Storage coefficients of 0.01 for confined areas of the lower aquifer and 0.18 for water-table areas of the lower aquifer were used in the calibrated transient model. A uniform 25-percent increase in storage coefficient resulted in slightly higher hydraulic heads in the valley aquifer. A uniform 25-percent decrease in storage coefficient resulted in slightly lower hydraulic heads in the valley aquifer. The deviations in hydraulic head (for a 25- 


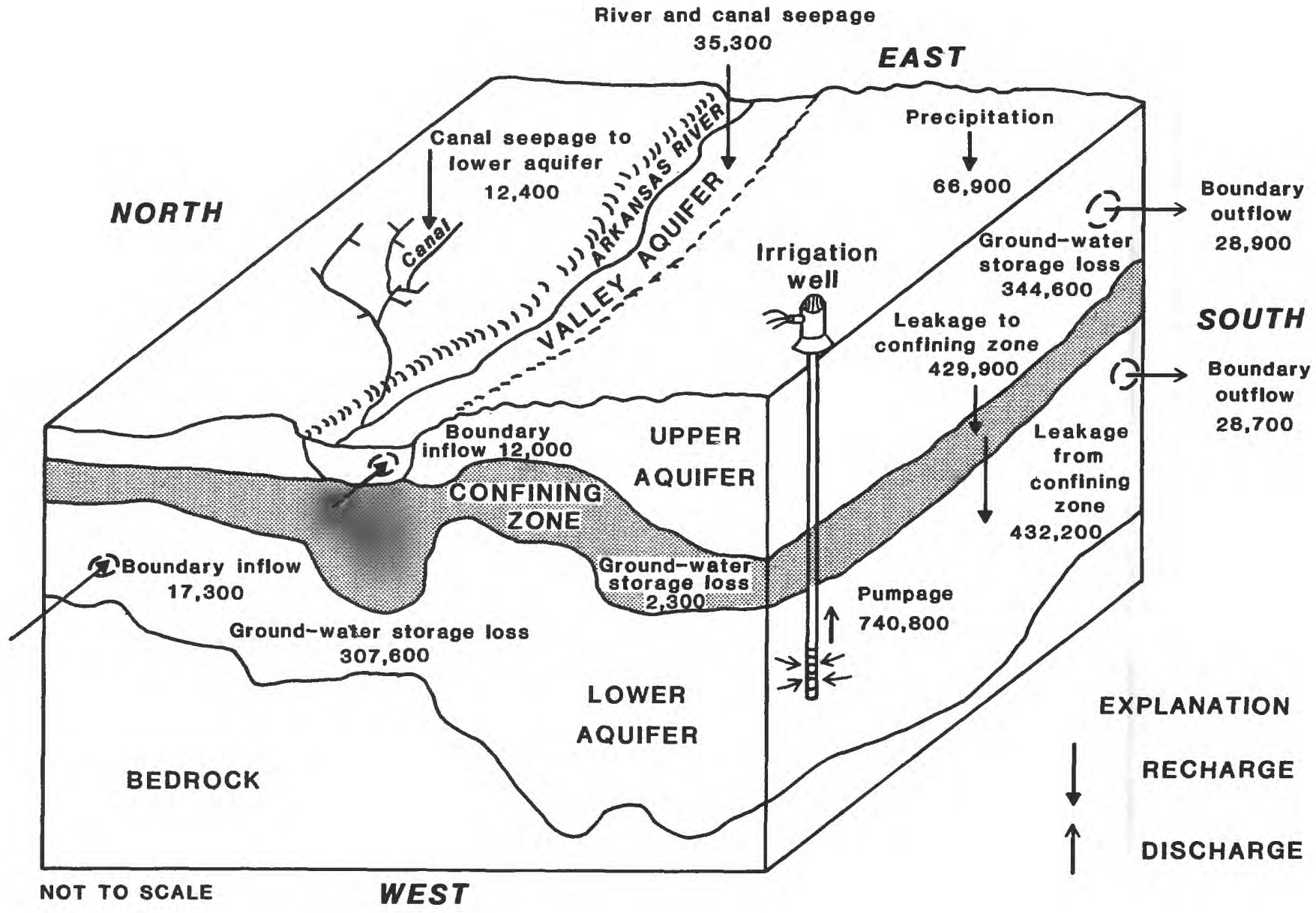

Values are in acre-feet per year

Figure 28. Simulated water budget for unconsolidated aquifer system, 1980 .

percent increase or decrease in storage coefficient) from the calibrated hydraulic head on December 31, 1980, were less than 2 feet.

Aquifer-leakance values used in the calibrated transient model were variable. A uniform 50-percent increase in aquifer leakance resulted in much lower hydraulic heads in the valley aquifer, nearly 6 feet lower than the calibrated head on December 31, 1980. A uniform 50percent decrease in aquifer leakance resulted in much higher hydraulic heads in the valley" aquifer, nearly 8 feet higher than the calibrated head on December 31, 1980.

\section{Response of Lower Aquifer}

The response of the lower aquifer to changes in natural recharge was very similar to the response of the valley aquifer to the same changes. A 50-percent increase in natural recharge resulted in higher hydraulic heads in the lower aquifer, while a 50-percent decrease in natural recharge resulted in lower hydraulic heads. The maximum deviation in hydraulic head (for a 50-percent increase or decrease in natural recharge) in the cross section from the calibrated hydraulic head was about 3 feet.

A uniform 25-percent increase in storage coefficient of the lower aquifer resulted in higher hydraulic heads in the lower aquifer, the maximum deviation from the calibrated head being more than 8 feet. A uniform 25-percent decrease in storage coefficient resulted in lower hydraulic heads in the lower aquifer, the maximum deviation from the calibrated head being more than 13 feet. Figure 30 shows that the response (change in hydraulic heads) to changes in storage coefficient varied significantly along the cross section. The response was greatest north of the Arkansas River, where much of the lower aquifer was under water-table conditions (and the storage coefficient had been changed to 0.18 ) by December 31, 1980.

A uniform 50-percent increase in aquifer leakance resulted in generally higher hydraulic heads in the lower aquifer, while a uniform 50-percent decrease resulted in generally lower hydraulic heads. The maximum deviations in hydraulic head (for a 50-percent increase or decrease in aquifer leakance), both plus and minus, from the cali- 

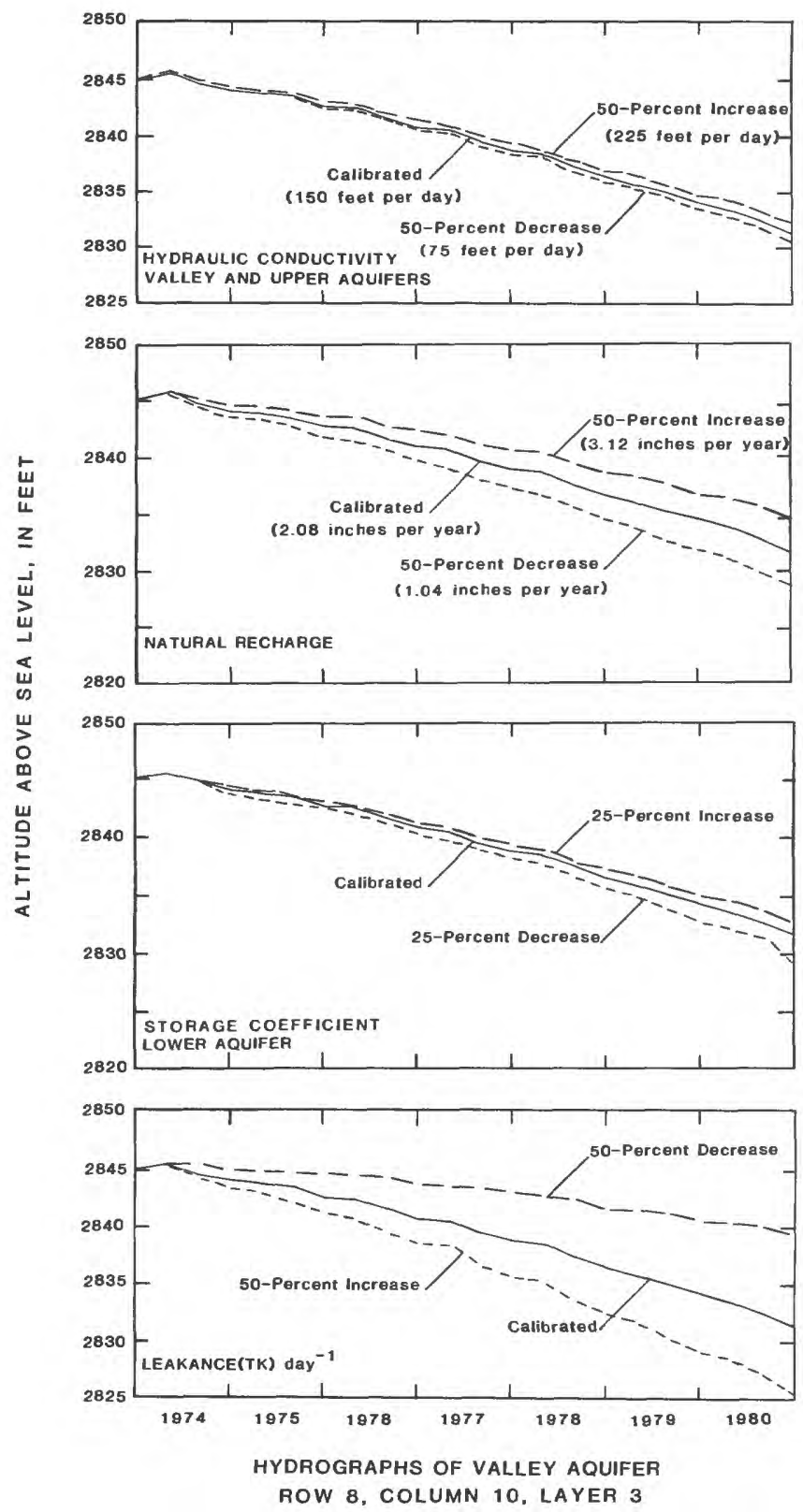

Figure 29. Response of simulated hydraulic heads in valley aquifer to changes in selected hydrologic values.

brated hydraulic heads were less than 3 feet. Higher aquifer leakance allowed more water to leak downward from the valley aquifer through the confining zone to the lower aquifer, resulting in the rise in hydraulic heads in the lower aquifer and the decline in hydraulic heads seen in the valley aquifer.

A summary of the sensitivity tests is shown in table 3. The sensitivity analysis showed that changes in aquifer leakance caused the greatest changes in hydraulic head in the valley aquifer, while changes in hydraulic conductivity of the valley and upper aquifers caused the smallest head changes. Changes in storage coefficient of the lower aquifer produced the greatest changes in hydraulic head of the lower aquifer, while aquifer leakance caused much smaller head changes.

\section{Hypothetical Conditions}

The predictive capabilities of the calibrated transient model permit hypothetical conditions to be explored by simply changing hydrologic values to produce the situations desired. A series of model simulations were made to evaluate the response of the unconsolidated aquifer system to past and future hypothetical hydrologic conditions.

\section{Response to Pumpage Changes in Sandhills for 1974-80}

A transient model simulation was made to test the effect of having no pumpage in the sandhills from 1974 80 on the water levels in wells tapping the valley and lower aquifers. Some residents in the area believe that the dry Arkansas River channel and the increase in waterlevel declines in wells on the high plains during the mid1970 's can be attributed directly to increases in pumpage in the sandhills during 1974-80.

The 1974-80 simulated decline in the potentiometric surface of the lower aquifer from the calibrated transient model ranged from less than 20 feet to about 80 feet when the actual 1974-80 pumpage in the sandhills was included (fig. 31). The simulated decline in the sandhills ranged from less than 20 feet to about 60 feet.

A hypothetical model simulation showed the decline in the potentiometric surface of the lower aquifer if no pumpage had occurred in the sandhills from 1974 to 1980 , a reduction in total pumpage (1974-80) of 39 percent (fig. 32). A comparison with figure 31 shows that declines in the potentiometric surface of the lower aquifer in the sandhills would be greatly reduced, ranging from less than 20 to about 40 feet, while the declines on the high plains would be only slightly reduced.

A comparison of water levels in selected observation wells shows the effect of pumpage in the sandhills during 1974-80. With no pumpage in the sandhills from $1974-80$, the water table in the valley aquifer would still decline near Lakin and near Holcomb (fig. 33). The altitude of the streambed nearest to each observation well is shown on hydrographs of the valley aquifer. The water table in the valley aquifer was still below the streambed altitude near Lakin and Holcomb, indicating that groundwater discharge to the river would not re-occur if pumpage had ceased in the sandhills from 1974-80. Therefore, this simulation indicated that pumpage in the sandhills was not totally responsible for the water-table declines in the valley aquifer or for the decreased ground-water discharge to the Arkansas River.

Also, a comparison of water levels in wells tapping 


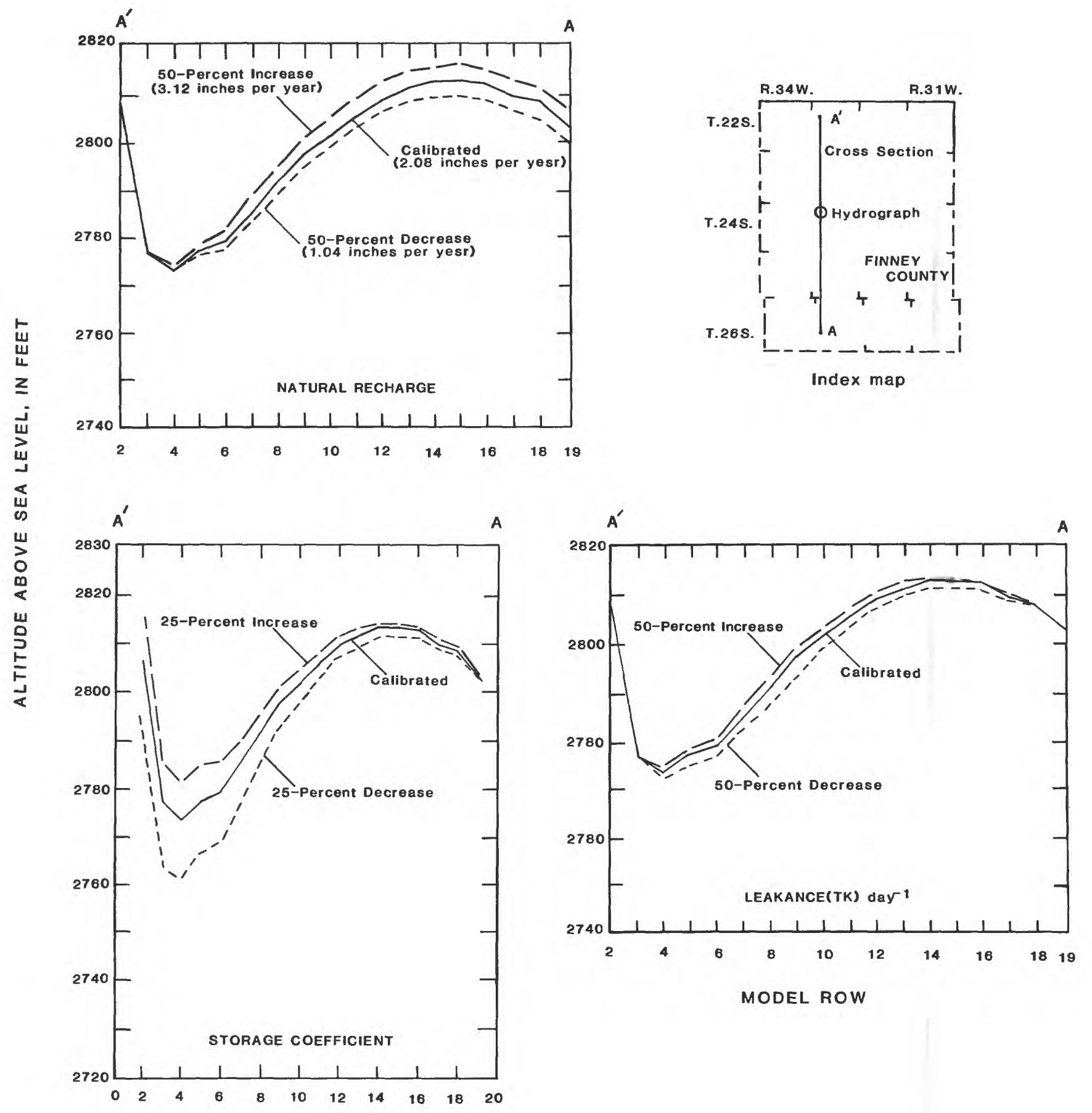

MODEL ROW

SIMULATED HYDRAULIC HEAD IN LOWER AQUIFER ON DECEMBER 31, 1980 SECTION THROUGH COLUMN 10 OF MODEL GRID

Figure 30. Response of simulated hydraulic heads in lower aquifer to changes in selected hydrologic values.

the lower aquifer indicates that there is little difference in water-level declines on the high plains (node B) with or without pumpage in the sandhills from 1974-80. A lesser rate of decline would have occurred near Lakin (node A) and Holcomb (node C), while water levels in wells would nearly stabilize at pre-1974 levels in the sandhills (node D), if pumpage in the sandhills had ceased from 1974-80. 
Table 3. Summary of sensitivity tests

[Negative ( - ) denotes decline in hydraulic head]

\begin{tabular}{|c|c|c|c|c|}
\hline \multirow[b]{2}{*}{$\begin{array}{c}\text { Aquifer } \\
\text { characteristic }\end{array}$} & \multirow[b]{2}{*}{$\begin{array}{l}\text { Percentage } \\
\text { change }\end{array}$} & \multirow[b]{2}{*}{$\begin{array}{l}\text { Hydrologic } \\
\text { value }\end{array}$} & \multicolumn{2}{|c|}{ Change in hydraulic heads, in feet } \\
\hline & & & $\begin{array}{c}\text { Valley aquifer, } \\
\text { deviation from } \\
\text { calibrated hydrograph } \\
\text { on December } 31,1980\end{array}$ & $\begin{array}{l}\text { Lower aquifer, } \\
\text { maximum change } \\
\text { in cross section }\end{array}$ \\
\hline $\begin{array}{l}\text { Hydraulic conduc- } \\
\text { tivity of valley } \\
\text { and upper aquifers. }\end{array}$ & $\begin{array}{l}\text { Increase } 50 \\
\text { Decrease } 50\end{array}$ & $\begin{array}{r}225 \text { feet per day } \\
75 \text { feet per day }\end{array}$ & $\begin{array}{l}+0.59 \\
-0.81\end{array}$ & $\begin{array}{l}-5.86 \\
+0.60\end{array}$ \\
\hline Natural recharge & $\begin{array}{l}\text { Increase } 50 \\
\text { Decrease } 50\end{array}$ & $\begin{array}{l}3.12 \text { inches } \\
\text { per year } \\
1.04 \text { inches } \\
\text { per year }\end{array}$ & $\begin{array}{l}+2.86 \\
-2.98\end{array}$ & $\begin{array}{l}+3.17 \\
-3.17\end{array}$ \\
\hline $\begin{array}{l}\text { Storage coefficient } \\
\text { of lower aquifer. }\end{array}$ & $\begin{array}{l}\text { Increase } 25 \\
\text { Decrease } 25\end{array}$ & $\begin{array}{c}\text { Variable } \\
\text { do. }\end{array}$ & $\begin{array}{l}+1.13 \\
-1.75\end{array}$ & $\begin{array}{r}+8.44 \\
-13.56\end{array}$ \\
\hline Aquifer leakance & $\begin{array}{l}\text { Increase } 50 \\
\text { Decrease } 50\end{array}$ & $\begin{array}{l}\text { do. } \\
\text { do. }\end{array}$ & $\begin{array}{l}-5.67 \\
+7.9\end{array}$ & $\begin{array}{l}+2.39 \\
-2.52\end{array}$ \\
\hline
\end{tabular}

\section{Projected Responses to Hypothetical Conditions of Streamflow and Pumpage for 1981-2005}

Four model simulations were made projecting hypothetical conditions of streamflow discharge in the Arkansas River and irrigation-canal diversions (henceforth called river and canal recharge) and pumpage from January 1981 through December 2005. The estimated pumpage using 1980 irrigated acreage and crop-water demand calculated with normal precipitation and temperatures is referred to as 1980 normal pumpage. For discussion herein, these projections are numbered 1 through 4 . The additional water-level decline from 1981 to 2005 (in addition to that experienced from 1974-80) was used to illustrate the lower-aquifer response.

\section{Response to Streamflow Conditions of 1979}

In projection 1, hydrologic conditions were simulated assuming 1980 normal pumpage, 1979 conditions of Arkansas River and irrigation-canal recharge, and normal (1941-70) precipitation. Arkansas River streamflow was very low during 1979 (fig. 6), resulting in low surface-water contributions to the unconsolidated aquifer system from the river and irrigation canals. A specific yield of 0.18 was used where the lower aquifer was unconfined. Projected water use from Iowa Beef Packers and from electric-generating unit 1 of the Sunflower Electric Plant were added to the pumpage during 1982 and 1983, respectively. The municipal water use for Garden City was eventually increased by 50 percent based on population studies by the Garden City Chamber of Commerce. Projection 1 indicated that the additional decline in the potentiometric surface of the lower aquifer would range from less than 50 feet to over 150 feet by 2005 (fig. 34). The greatest decline would occur in eastern Kearny County and western Finney County.

Projection 1 also indicated that the water table in the valley aquifer would continue to decline, resulting in continued seepage losses along the river when reservoir water is transported to the irrigation canals. Although seepage losses currently are maximized near Lakin because the ground-water level is below the altitude of the confining material in the streambed (hydraulic connection between the valley aquifer and the river has been broken), seepage losses would increase west of Lakin where the water table is at or above the streambed altitude.

By 2005, much of the valley and upper aquifers would be dewatered. This would result in a decrease in recharge to the lower aquifer. Therefore, the sandhills and the Arkansas River valley could expect an increase in water-level declines in areas where the upper and valley aquifers have been dewatered and the lower aquifer has remained confined, much like the high plains experienced during the mid-1970's.

The saturated thickness of the lower aquifer during 2005, resulting from the hypothetical conditions used in projection 1 , is shown in figure 35 . At this time, most of the lower aquifer would be under water-table conditions. The figure shows that from 50 to about 250 feet of saturation would occur in the sandhills, while less than 50 to about 150 feet of saturation would occur on the 


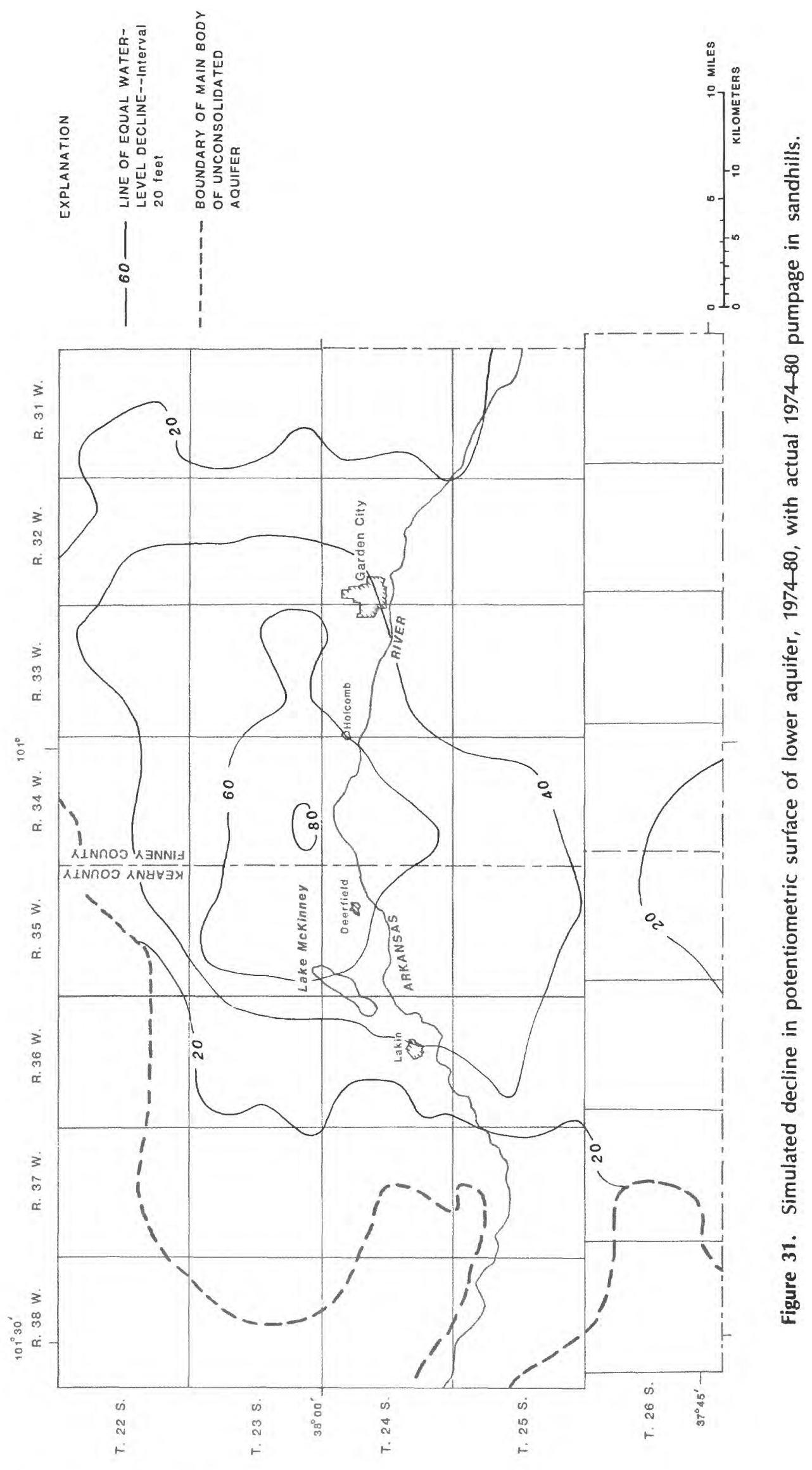




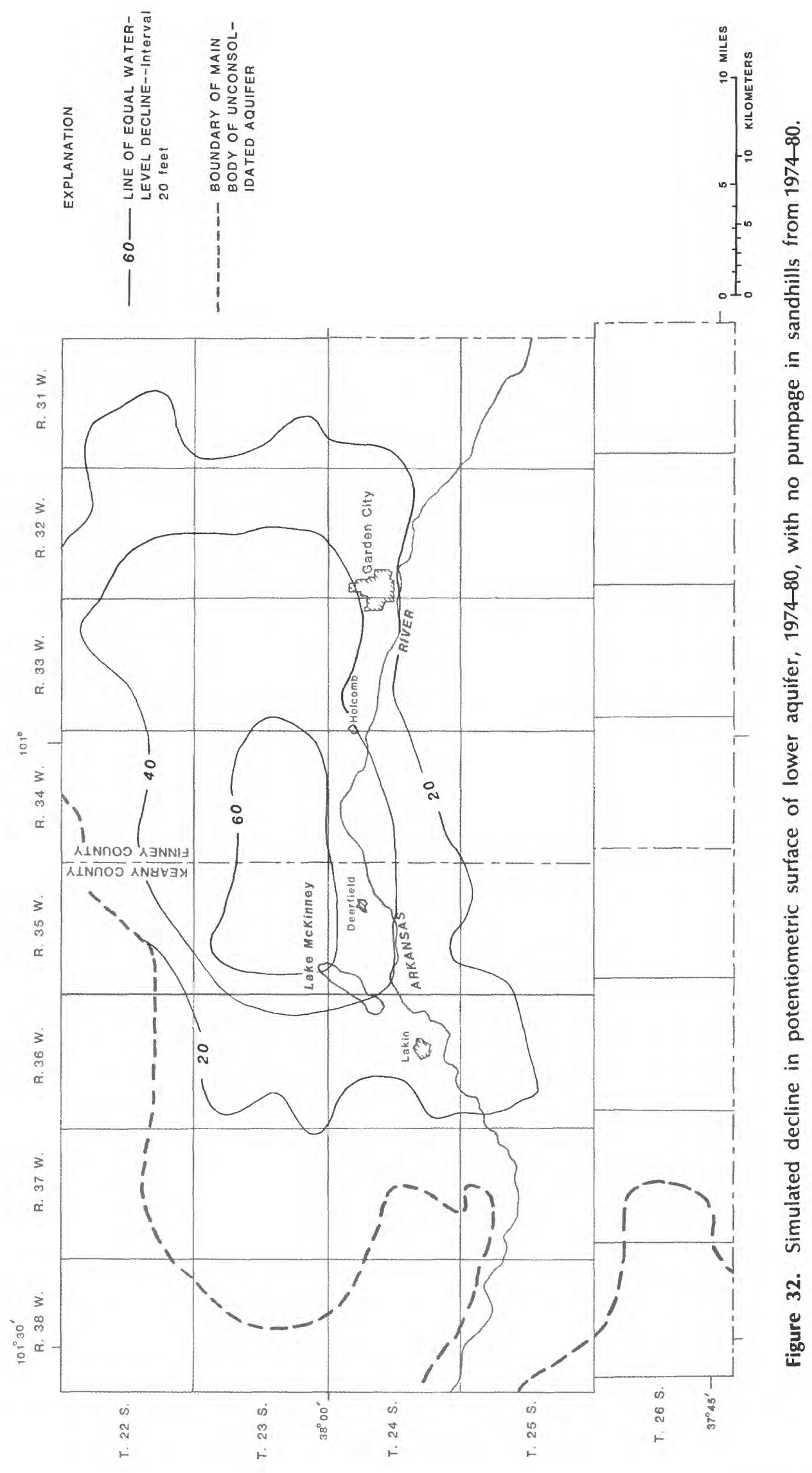



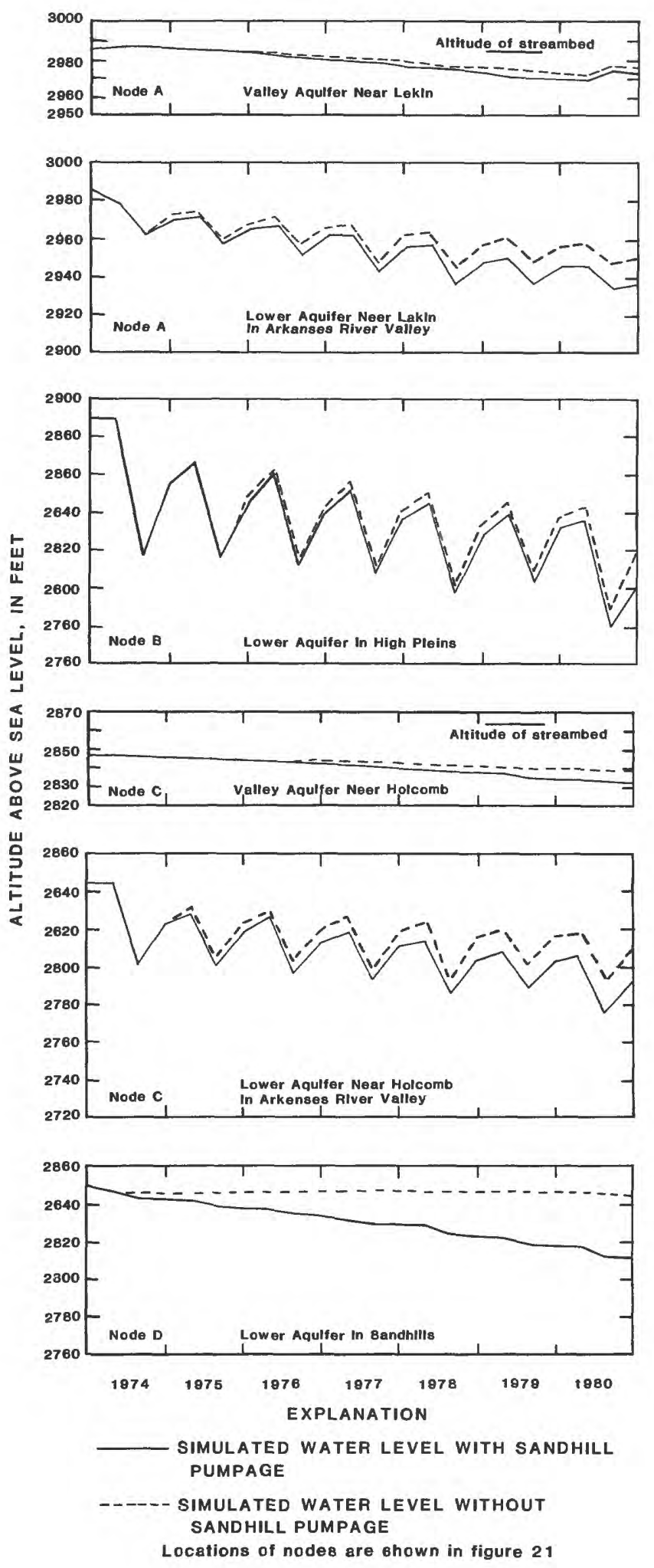

Figure 33. Simulated water levels in selected observation wells, with and without pumpage in sandhills, 1974 80. high plains. Less than 50 feet of saturation could be expected in northwestern Kearny County.

Based solely on the amount of water remaining in the study area during 2005, irrigation could still be occurring in the sandhills and on the high plains. An exception could be in northwestern Kearny County due to the decrease in saturated thickness. The high plains could expect a decrease in well yield because of the projected reduction in saturated thickness.

\section{Response to Streamflow Conditions of 1980}

In projection 2 , hydrologic conditions were simulated assuming that the 1980 recharge from the Arkansas River and irrigation canals continued for the next 25 years. This projection used 1980 normal pumpage and normal (1941-70) precipitation. Pumpage by Iowa Beef Packers, the Sunflower Electric Plant, and municipalities was the same as in projection 1. Arkansas River streamflow was much higher during 1980 compared to 1979 (fig. 6), resulting in high surface-water contributions to the unconsolidated aquifer system from the river and irrigation canals. The additional decline in the potentiometric surface of the lower aquifer would range from less than 50 feet to about 150 feet by 2005 (fig. 36). With the additional recharge from the Arkansas River and irrigation canals, the greatest head declines would be south of Deerfield and Holcomb in the sandhills. Head declines near the river in eastern Kearny County and western Finney County were reduced by as much as 18 feet compared to declines experienced in projection 1. Therefore, the amount of recharge from the Arkansas River and irrigation canals will influence future hydraulic-head declines near the river. Besides contributing recharge to the unconsolidated aquifer system, increased flow in the irrigation canals also reduces the amount of ground water needed for irrigation on the high plains.

Even with 1980 conditions of river and canal recharge for 25 consecutive years, the water table in the valley aquifer would continue to decline. In other words, water would leak downward from the valley aquifer faster than river and canal recharge (by seepage) can replace it. Therefore, in order to reduce future seepage losses during reservoir releases to the river, the altitude of the water table in the valley aquifer must increase to near the altitude of the river stage. This could be done by (1) decreasing the number of wells pumping in the study area (thereby decreasing the gradient between hydraulic heads in the lower aquifer and hydraulic heads in the valley aquifer) to reduce downward leakage from the valley aquifer through the confining zone to the lower aquifer, or (2) increasing streamflow discharge in order to recharge the valley aquifer. When the water-table altitude in the 


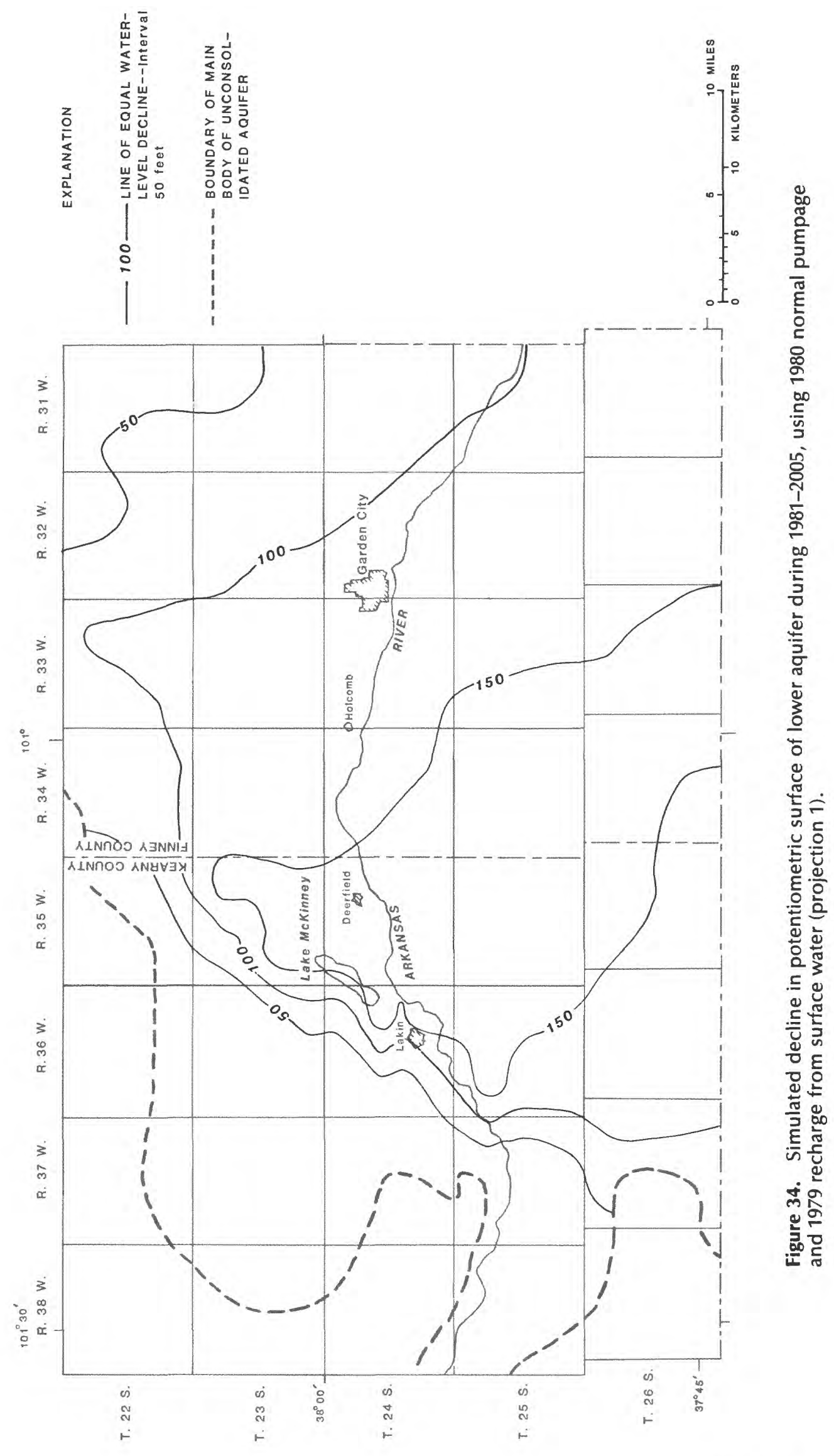




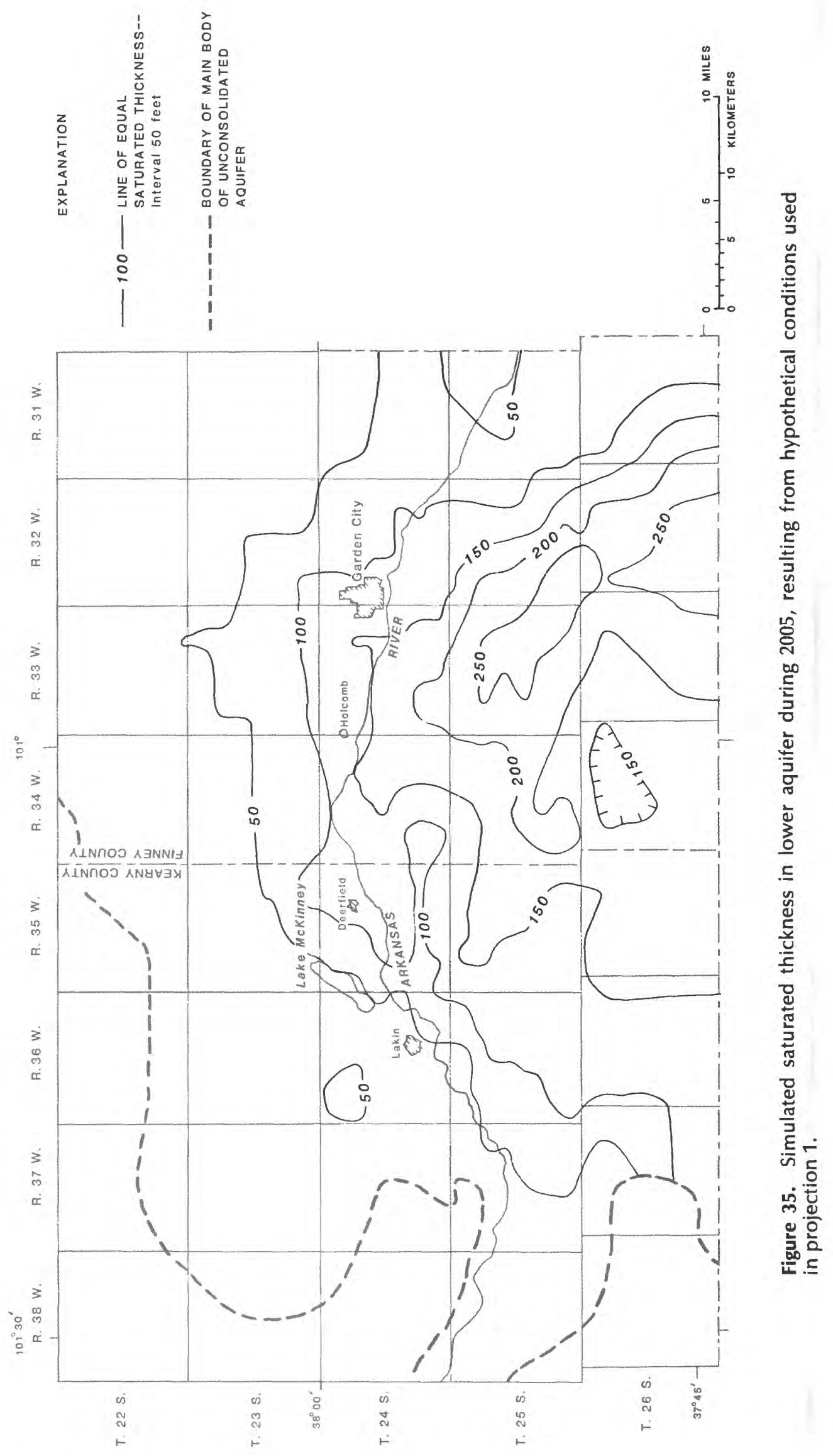




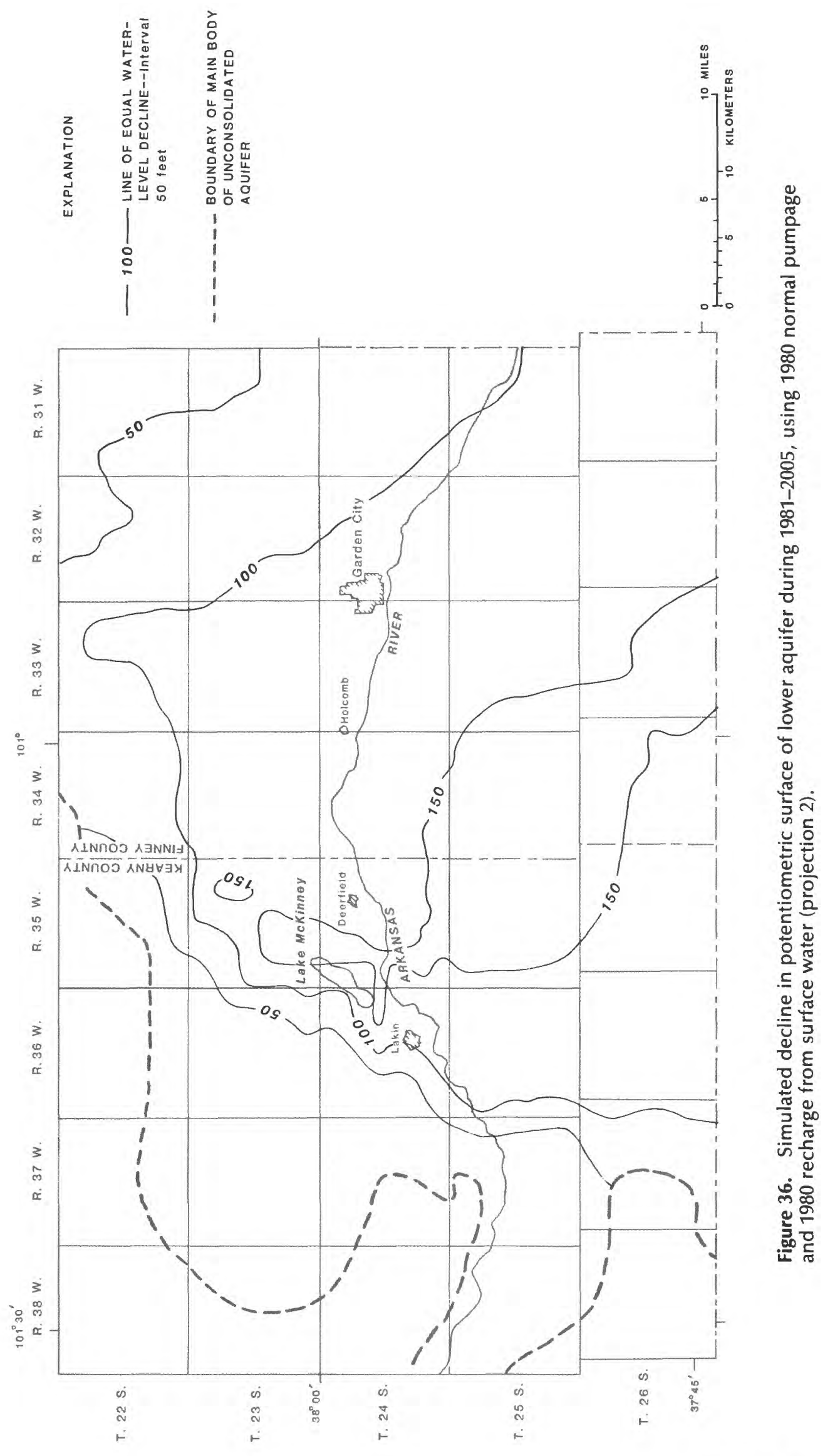


valley aquifer approximates the river-stage altitude, seepage losses would be minimized.

It is improbable that either 1979 or 1980 recharge from the Arkansas River and canals will continue for 25 consecutive years; recharge as a mixture of high and low flows would be more likely. The reader can interpolate an approximate potentiometric-surface decline in the lower aquifer by forecasting the amount of recharge expected during the next 25 years.

\section{Response to Increased Industrial Pumpage}

In projection 3, hydrologic conditions were simulated assuming 1979 conditions of Arkansas River and irrigation-canal recharge, normal (1941-70) precipitation, and 1980 normal pumpage, plus the additional groundwater withdrawal needed for electric-generating units 2 and 3 at the Sunflower Electric Plant. Water use for units 2 and 3 was added pumpage during 1991 and 1998, respectively. The total estimated water use for units 1,2 , and 3 during 1998 was 14,535 acre-ft/yr (David Pope, Division of Water Resources, Kansas State Board of Agriculture, written commun., 1981). The additional decline in the potentiometric surface of the lower aquifer as a result of the additional pumpage requirements of electricgenerating units 2 and 3 would range from less than 2 feet to about 10 feet (fig. 37). The general location of the Sunflower Electric well field is in the center of the potentiometric-surface decline shown in figure 37.

Response to Increased Irrigation Pumpage

As of 1981, some areas of the sandhills were still available for additional irrigation development. Southwest Kansas Groundwater Management District No. 1 does not recommend the approval of water rights for new wells if the new and existing pumpage would deplete the unconsolidated aquifer system over 40 percent in 25 years. In projection 4, hydrologic conditions were simulated assuming 1979 conditions of Arkansas River and irrigation-canal recharge, 1980 normal pumpage, and normal (1941-70) precipitation. However, 1980 normal pumpage was increased by 36,625 acre-ft/yr to include additional new wells that would presently meet the management district's criteria. Personnel from the management district estimated the well locations and pumpage rates that would likely meet their criteria. All of the new locations were in the sandhills. Pumpage by lowa Beef Packers, the Sunflower Electric Plant, and municipalities was the same as for projection 1 .

The additional decline in the potentiometric surface of the lower aquifer as a result of the hypothetical conditions used in projection 4 would range from less than 50 feet to over 150 feet (fig. 38). If compared to hydraulic-head declines in projection 1 , as much as 20 feet of additional decline would occur in the sandhills, but de- clines on the high plains would remain similar to those in projection 1 .

\section{SUMMARY}

The unconsolidated deposits of Miocene and Pleistocene age are the major sources of water in Kearny and Finney Counties, southwestern Kansas. This unconsolidated aquifer system, consisting of three aquifers and a confining zone, underlies nearly 850,000 acres in the study area. Transient model calibration of specific yield of the unconfined valley and upper aquifers is 0.18 , and the hydraulic conductivity is $150 \mathrm{ft} / \mathrm{d}$. The calibrated storage coefficient of the confined lower aquifer is 0.01 , and the hydraulic conductivity is $115 \mathrm{ft} / \mathrm{d}$.

During 1980, about 2,900 irrigation wells pumped an estimated 738,000 acre-feet of water to irrigate approximately 320,000 acres. Most of the pumpage was from the lower aquifer. The use of water for irrigation has caused the potentiometric surface of the lower aquifer to decline 20 to 80 feet from 1974-80. This decline has induced downward leakage from the overlying aquifers and resulted in water-table declines in the valley and upper aquifers. The water table in the valley and upper aquifers is below the streambed altitude in the study area, and little or no ground water discharges to the river.

Hydrographs indicate that the upper aquifer has been dewatered on the high plains since the mid-1970's. This has reduced the recharge to the lower aquifer, resulting in an increased rate of water-level decline in wells. The water-level decline in selected wells before the upper aquifer was dewatered averaged less than $1 \mathrm{ft} / \mathrm{yr}$, whereas during the late 1970's the decline averaged over $9 \mathrm{ft} / \mathrm{yr}$. The increased rate of water-level decline in wells completed in the lower aquifer occurred during the interval of time when the upper aquifer was dewatered, and the lower aquifer remained confined. When the hydraulic heads in the lower aquifer drop below the bottom of the confining zone, the lower aquifer will no longer be confined, and it will adjust to water-table conditions (a higher storage coefficient), resulting in a decrease in the rate of decline in hydraulic heads.

The Arkansas River lies atop the valley aquifer. Once an intermittent stream, the river is currently (1982) dry much of the time in the western part of the study area, except for times when water is released from John Martin Reservoir in Colorado. Seepage losses can be as high as 75 percent when reservoir water is transported 22 river miles through the study area to irrigation canals. The amount of water diverted from the Arkansas River for irrigation decreased during the 1970's, corresponding to a decrease in river discharge. In the eastern part of the study area, the river is dry most of the time. The decrease in Arkansas River streamflow can be attributed 


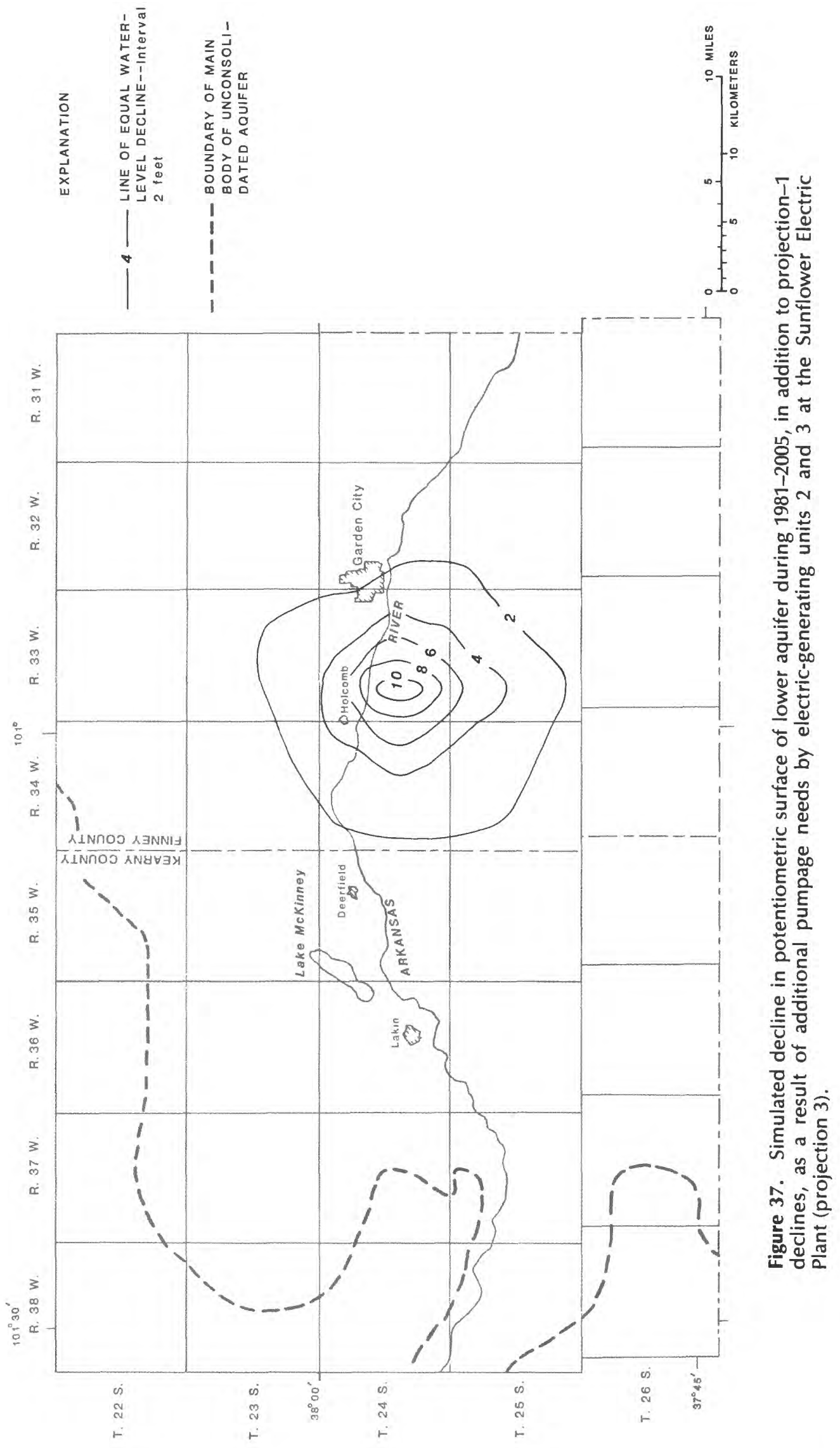




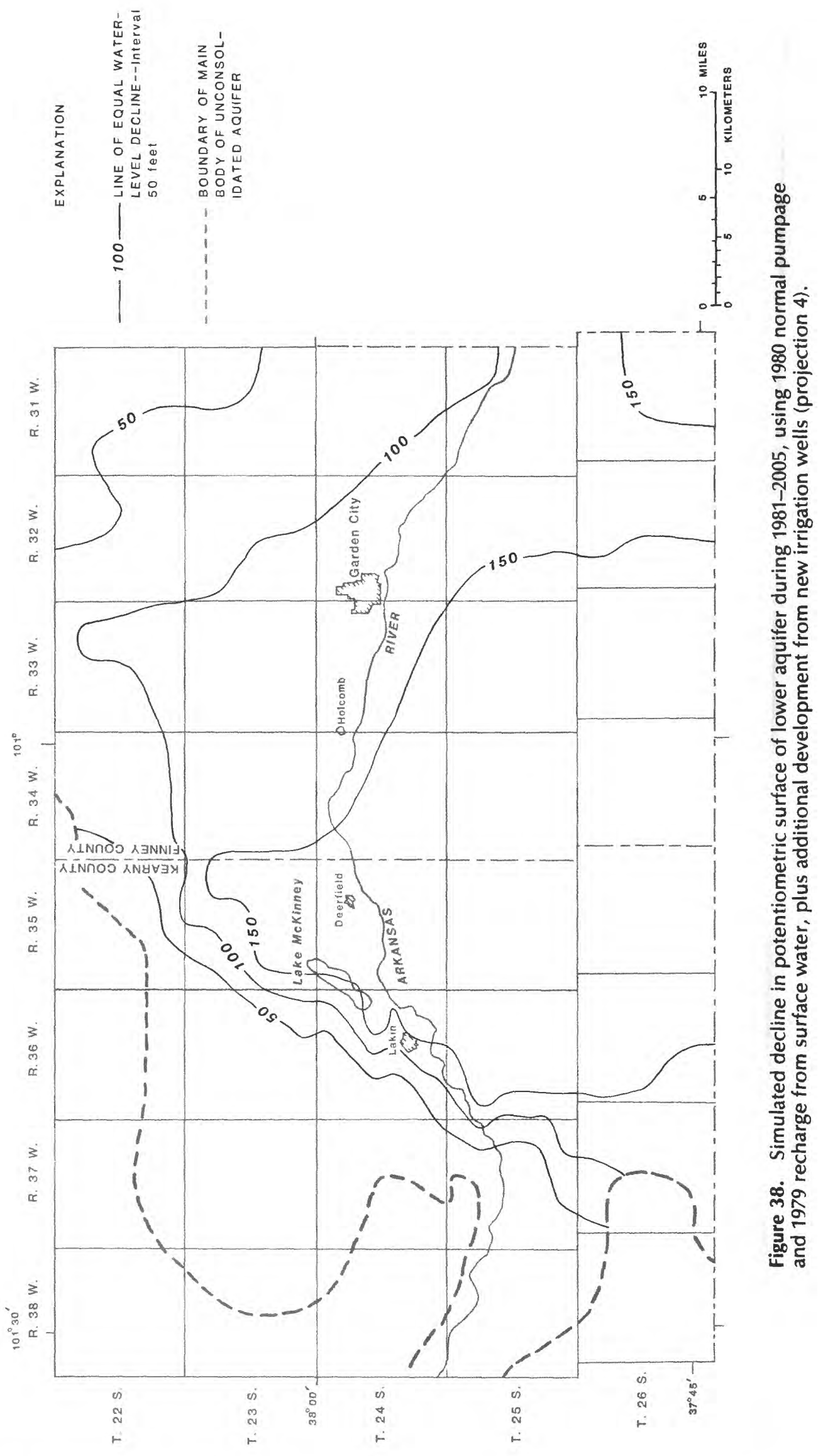


"o the decrease in ground-water discharge to the river due io the declining water table in the valley aquifer and to decreased flow from upstream in the phase-I study area and in Colorado.

Seepage losses from the Arkansas River are a major nource of recharge to the aquifer system. West of the Bear Treek fault zone, the water table in usually within a few set of the streambed altitude. When a river discharge of greater than $75 \mathrm{ft}^{3} / \mathrm{s}$ occurs at Kendall, the water-table and river-stage altitudes are similar, and seepage losses are small. However, east of the Bear Creek fault, the water table is farther below the streambed because of greater irrigation and greater water-table declines in the "alley aquifer. When streamflow occurs, recharge to the "alley aquifer begins. But the rising water table usually toes not reach the altitude of river stage, and seepage sontinues to occur. Additionally, a water-table rise in the "alley aquifer corresponds to an increase in the downvard-leakage rate to the lower aquifer (because of a greator difference in hydraulic heads between the two aqui$f_{\text {ers), }}$ which hinders the rise in the water table in the valoy aquifer.

Transient model simulations indicated that, during 1980 , the lower aquifer was recharged by:

1. Leakage from the confining zone $(432,200$ acre-feet);

2. Lateral, subsurface inflow (17,300 acre-feet); and

3. Canal seepage (12,400 acre-feet).

The lower aquifer was discharged by:

1. Lateral, subsurface outflow $(28,700$ acrefeet); and

2. Pumpage $(740,800$ acre-feet $)$.

The decrease in storage in the lower aquifer was 307,600 acre-feet.

The simulated 1980 water budget showed that 42 zercent of the ground water pumped from the lower aquifer came from storage in the lower aquifer. Therefore, 'he major source (nearly 58 percent) of water for pumpage is from downward leakage of water from the overlying upper and valley aquifers.

Results of model experimentation with hypothetical 1974-80 conditions showed that if no pumpage had occurred in the sandhills during 1974-80, the water table in the valley aquifer would still decline near Lakin and "Iolcomb. The potentiometric surface of the lower aquifer "vould :

1. Decline in the high plains at a similar rate as when sandhill pumpage had occurred;

2. Decline slightly in the Arkansas River valley; and

3. Stabilize or decline slightly in the sandhills.

Model projections from 1981 to 2005 indicated that under continued conditions of normal (1941-70) precipitaion, 1980 irrigated acreage, and 1979 rates of recharge from the river and canals, the additional decline in the potentiometric surface of the lower aquifer (in addition to that occurring from 1974-80) would range from less than 50 feet to over 150 feet by 2005 . Most of the valley and upper aquifers would be dewatered by this time. This would result in decreased recharge to the lower aquifer and increased hydraulic-head declines in the sandhills and the Arkansas River valley, similar to the declines on the high plains during the mid-1970's. Saturated thickness would range from about 50 to about 250 feet in the sandhills and from about 50 feet to about 150 feet on the high plains. Based solely on the remaining saturated thickness in 2005, irrigation could still be occurring in the sandhills and on the high plains.

If 1980 conditions of recharge from the river and canals continued from 1981-2005, the additional decline in the potentiometric surface of the lower aquifer would range from less than 50 feet to about 150 feet. Declines in hydraulic head near the river in eastern Kearny County and western Finney County would be reduced by as much as 18 feet compared to declines experienced under 1979 conditions of river and canal recharge. Therefore, the amount of recharge from the river and canals could influence future water- level declines near the river. Even with 1980 conditions of river and canal recharge, the water table in the valley aquifer would continue to decline because of downward leakage through the confining zone to the lower aquifer. Streamflow seepage losses could be decreased by (1) decreasing the number of wells pumping from the lower aquifer in the study area in order to reduce downward leakage from the valley aquifer, or (2) increasing streamflow discharge in order to recharge the valley aquifer. When the water table in the valley aquifer approximates the altitude of the river stage, seepage losses would be minimized.

\section{REFERENCES}

Barker, R. A., Dunlap, L. E., and Sauer, C. G., 1981, Analysis and computer simulation of stream-aquifer hydrology, Arkansas River valley, southwestern Kansas: U.S. Geological Survey Water-Supply Paper 2200, 29 p.

Burkham, D. E., 1970, A method for relating infiltration rates to streamflow rates in perched streams: U.S. Geological Professional Paper 700-D, p. D266-D271.

Dunlap, L. E., 1980, Simulated water-level declines near Marienthal, west-central Kansas: U.S. Geological Survey Water-Resources Investigations 80-39, 15 p.

Dunlap, L. E., Kume, Jack, and Thomas, J. G., 1980, Geohydrology and model analysis for water-supply management in a small area of west-central Kansas: U.S. Geological Survey Water-Resources Investigations 80-91, $59 \mathrm{p}$.

Gutentag, E. D., Lobmeyer, D. H., and McGovern, H. E., 1972, Ground water in Kearny County, southwestern Kansas: U.S. Geological Survey Hydrologic Investigations Atlas HA-416, scale $1: 250,000,2$ sheets.

Gutentag, E. D., Lobmeyer, D. H., McGovern, H. E., and 
Long, W. A., 1972, Ground water in Finney County, southwestern Kansas: U.S. Geological Survey Hydrologic Investigations Atlas HA-442, scale: 1:250,000, 3 sheets.

Gutentag, E. D., and Weeks, J. B., 1981, Evaluating vertical variability of transmissivity and specific yield for the High Plains Regional Aquifer Systems Analysis: Geological Society of America abstracts with programs, Rocky Mountain Section, v. 13, no. 4, p. 199.

Lappala, E. G., 1978, Quantitative hydrogeology of the Upper Republican Natural Resources District, southwest Nebraska: U.S. Geological Survey Water-Resources Investigations 78$38,209 \mathrm{p}$.

Latta, B. F., 1944, Geology and ground-water resources of Finney and Gray Counties, Kansas: Kansas Geological Survey Bulletin 55, 272 p.

Lindgren, R. J., 1982, Determination of irrigation pumpage in parts of Kearny and Finney Counties, southwestern Kansas: U.S. Geological Survey Water-Resources Investigations 824011,26 p.

McLaughlin, T. G., 1943, Geology and ground-water resources of Hamilton and Kearny Counties, Kansas: Kansas Geological Survey Bulletin 49, 220 p.

Meyer, W. R., Gutentag, E. D., and Lobmeyer, D. H., 1970, Geohydrology of Finney County, southwestern Kansas: U.S. Geological Survey Water-Supply Paper 1891, 117 p.

Moore, J. E., and Wood, L. A., 1967, Data requirements and preliminary results of an analog-model evaluation-Arkansas River Valley in eastern Colorado: Ground Water, v. 5, no. 1 , p. 20-23.

National Oceanic and Atmospheric Administration, 1940-80,
Climatological Data: National Climatic Center monthly n port.

Prill, R. C., 1977, Movement of moisture in the unsaturate zone in a loess-mantled area, southwestern Kansas: U.S Geological Survey Professional Paper 1021, 21 p.

Simonett, D. S., 1960, Development and grading of dunes western Kansas: Annals of the Association of America Geographers, v. 50, no. 3, p. 216-241.

Slichter, C. S., 1906, The underflow in Arkansas valley in wes ern Kansas: U.S. Geological Survey Water-Supply Pap $153,90 \mathrm{p}$.

Taylor, O. J., and Luckey, R. R., 1974, Water-manageme studies of a stream-aquifer system, Arkansas River Valle! Colorado: Ground Water, v. 12, no. 1, p. 22-38.

Trescott, P. C., 1975, Documentation of finite-difference mod for simulation of three-dimensional ground-water flow: U.S Geological Survey Open-File Report 75-438, 32 p.

Trescott, P. C., and Larson, S. P., 1976, Supplement to Oper File Report 75-438, documentation of finite-differenc model for simulation of three-dimensional ground-wate flow: U.S. Geological Survey Open-File Report 76-591, 2 p.

U.S. Department of Agriculture, 1963, Soil survey, Kearn County, Kansas: Soil Conservation Service, ser. 1959, nc $32,71 \mathrm{p}$.

1965, Soil survey, Finney County, Kansas: So Conservation Service, ser. 1961 , no. 30,91 p.

U.S. Geological Survey, 1978, Water resources investigation in Kansas, 1978: U.S. Geological Survey Water-Index Fol der. 